RENATO SOUZA DO NASCIMENTO

\title{
CULTURA LÚDICA DA JUVENTUDE BRASILEIRA \\ Rebeldia e consumo nas páginas da Veja e da Folha de São Paulo nas décadas de 1970 e 1980
}

SÃO PAULO

2008 
RENATO SOUZA DO NASCIMENTO

\section{CULTURA LÚDICA DA JUVENTUDE BRASILEIRA Rebeldia e consumo nas páginas da Veja e da Folha de São Paulo nas décadas de 1970 e 1980}

Dissertação apresentada ao Programa de PósGraduação em Comunicação, Área de Concentração Interfaces Sociais da Comunicação, Linha de Pesquisa Comunicação e Cultura, da Escola de Comunicações e Artes da Universidade de São Paulo, como exigência parcial para a obtenção do Título de Mestre em Comunicação Social, sob a orientação do Prof. Dr. Waldenyr Caldas.

SÃO PAULO

2008 


\section{FOLHA DE APROVAÇÃO}

\section{Renato Souza do Nascimento}

\section{CULTURA LÚDICA DA JUVENTUDE BRASILEIRA. Rebeldia e Consumo nas páginas da Veja e da Folha de São Paulo nas décadas de 1970 e 1980.}

Dissertação apresentada ao Programa de PósGraduação em Comunicação, Área de Concentração Interfaces Sociais da Comunicação, Linha de Pesquisa Comunicação e Cultura, da Escola de Comunicações e Artes da Universidade de São Paulo, como exigência parcial para a obtenção do Título de Mestre em Comunicação Social, sob a orientação do Prof. Dr. Waldenyr Caldas.

COMISSÃO EXAMINADORA

Prof. Dr.

Instituição Assinatura

Prof. Dr.

Instituição Assinatura

Prof. Dr. 
Para Djalma (In Memorian) e Terezinha, com gratidão. 


\section{AGRADECIMENTOS}

Tenho que admitir que essa é uma página que quase ninguém lê em uma dissertação. De fato, o momento dos Agradecimentos pode ser até meio piegas, pois muita gente exagera, transformando isso numa quase Elegia. Prefiro que meu texto tenda mais para uma Ode, algo mais entusiástico. O que não posso negar é que nesse espaço podemos reiterar o apoio recebido durante todo o período do mestrado e, quem passa pelo que passei, sabe o quanto todos descritos nessa parte são importantes. E, claro, não vou abrir mão desse direito para falar dessas pessoas especiais, também responsáveis pelo meu sucesso.

Primeiramente, agradeço ao professor, mestre e amigo Waldenyr Caldas, que me deu muitas broncas e disse NÃO por várias vezes, mas em todas o fez pra me ajudar. Pela paciência pelo projeto temático, à ajuda nas aulas de Teoria da Comunicação e das reuniões nos horários mais desmedidos, obrigado! A confiança dele no meu trabalho e na minha competência é que me fizeram realizar esse objetivo.

Ser nordestino em São Paulo não é fácil. Primeiro, porque já pensam que a gente vem pra servir mesa e, depois, por conta do choque cultural. Você olha para aqueles prédios na Avenida Paulista, assustado, boquiaberto com a magnitude das construções e diz: "acaba não, mundão!".

Por isso mesmo, agradeço a ajuda dos amigos paulistanos que fizeram ser bem mais fácil a minha adaptação na terra da garoa: as irmãs Jô e Jose Terto, que me emprestavam dos livros para as seleções até as anotações em sala de aula - que confesso, nunca fazia; meu cunhado - Ricardo - e Raquel, minha irmã (pela acolhida e ajuda nos momentos financeiros difíceis); e aos meus amigos, que me suportaram por esses quatro anos de São Paulo, Karina e Dudu, além de todas as outras pessoas que fizeram parte da minha vida na cidade grande. 
Agradeço também toda a minha família e amigos do Piauí, que sempre torceram, me deram apoio e me alegraram quando eu estive triste.

Agradeço à minha noiva, Carol, por ter acalentado meu coração nesses momentos de distância e solidão e, em especial à minha mãe - Terezinha -, que me deu além de todo o carinho e amor, a maior lição da minha vida: estudar é preciso.

Não poderia esquecer o meu inesquecível pai (Seu Djalma), que deve estar em algum lugar comemorando junto comigo. 
"Dos passos que caminhei só lembro a dor. A chegada é que me faz lembrar que também fui feliz no caminho".

Renato Souzan 


\section{RESUMO}

Ao se estudar a cultura da juventude, devemos analisá-la dentro do contexto de uma sociedade de consumo. Por isso mesmo, ligada à música e à moda (não no seu sentido estrito).

A cultura da juventude brasileira foi pautada principalmente pelas influências musicais internacionais, mas sempre dando uma "cara nova" aos movimentos juvenis que aqui se criavam, sendo o período entre as décadas de 1970 e 1980, o de maior efervescência e criatividade musical.

O objetivo desse trabalho é analisar esse tema com base na sua relação com a indústria cultural, apontando as especificidades da atuação do Mercado, tanto para a mercantilização de movimentos espontâneos da juventude, quanto para as estratégias envolvidas na criação de fenômenos ou "modismos".

Entender como esse processo se deu no nosso país é essencial para refletir os rumos da juventude atual e sua relação com o consumo.

A indústria cultural é formada por vários sistemas, sendo a mídia um deles. Por isso, com base em dois meios de comunicação impressos - a revista Veja e o jornal Folha de São Paulo, tentou-se traçar a relação entre a abordagem midiática e a consolidação dos movimentos ou fenômenos musicais pelo mercado cultural.

Palavras-chave: cultura da juventude brasileira, consumo, BRock, tropicalismo e indústria cultural. 


\begin{abstract}
When studying the culture of youth we should analyze it within the context of a consumer society. Therefore, connected to music and fashion (not in a strict sense).

The culture of Brazilian youth has been mostly guided by international musical influences, but the youth movements created here in Brazil have always received a new look, especially between the 70's and 80's, the period with the greater effervescence and musical creativity.

The goal of this work is to analyze this issue basing this analysis on its relation with cultural industry, pointing the specifics of market's performance both to the commercialization of spontaneous youth movements as well as to the strategies involved on the creation of phenomena and new "fashions". Understanding how that process has happened in our country is essential to think about the directions of the current youth and its relation with consumption.

The cultural industry is made up of various systems, including the media. Hence, based on two publications - Veja magazine and Folha de São Paulo newspaper, this work tries to describe the relationship between the media approach and the consolidation of musical movements, or phenomena, by the cultural market.
\end{abstract}

keywords: culture of Brazilian youth, consumption (economics), rock, tropicalismo e cultural industry. 


\section{LISTA DE FIGURAS}

Figura 1 - Reportagem: O êxito e a volta de Hair. 140

Figura 2 - Reportagem: Polícia prende mais de cem hippies na praça 140

Fonte: Folha de São Paulo, 12 de janeiro de 1970. 140

Figura 3 - Reportagem: Depois de Caetano 142

Figura 4 - Reportagem: A magia da música popular 142

Figura 5 - Reportagem: Papa Paulo VI fala à juventude. 144

Figura 6 - Reportagem: O Brasil acaba de descobrir um velho produto: o rock'n'roll

Figura 7 - Reportagem: Um frenesi. 149

Figura 8 - Reportagem: punks invadem São Vicente, destroem carros e são presos. 150 


\section{SUMÁRIO}

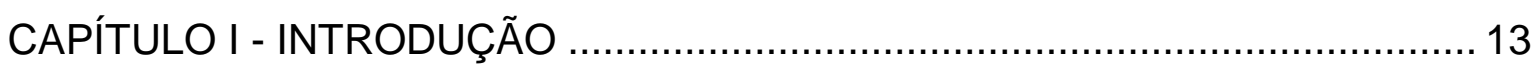

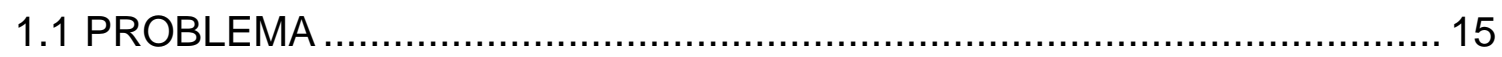

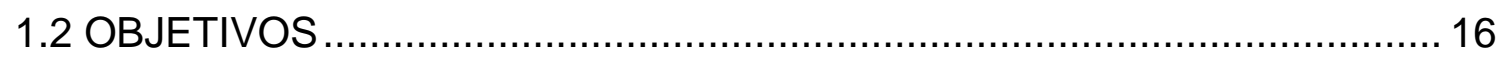

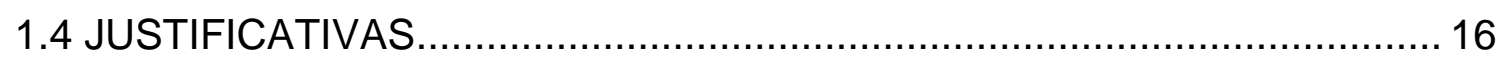

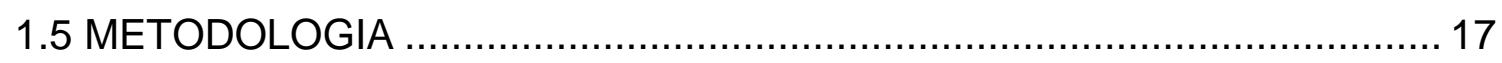

1.5.1 Embasamento teórico: Revisão Bibliográfica ……………………...... 17

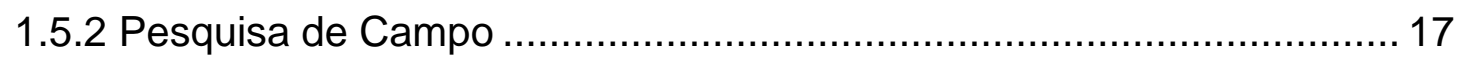

CAPÍTULO II - JUVENTUDE E INDÚSTRIA CULTURAL................................... 19

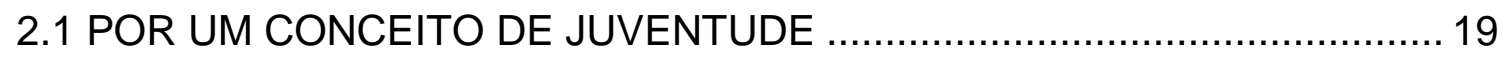

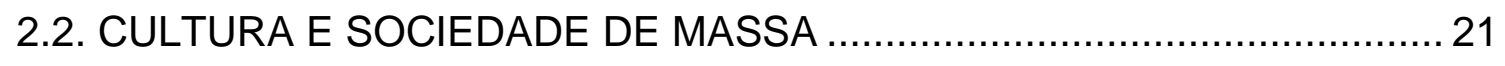

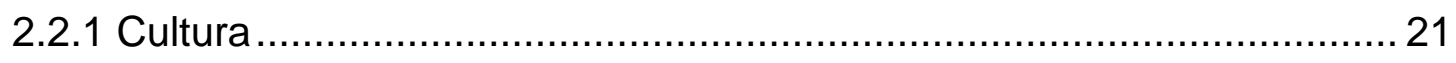

2.2.2 A alta cultura: do "melhor gosto" ao autoritarismo das elites................ 23

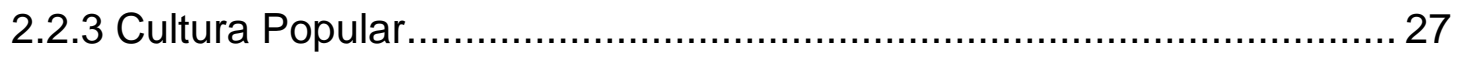

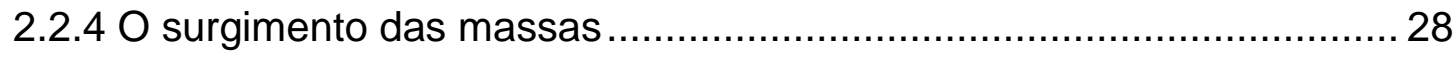

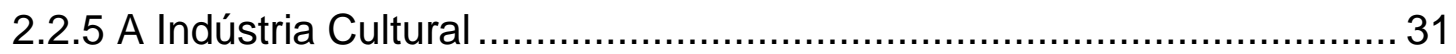

2.2.6 A Reprodutibilidade da Obra de arte ................................................ 36

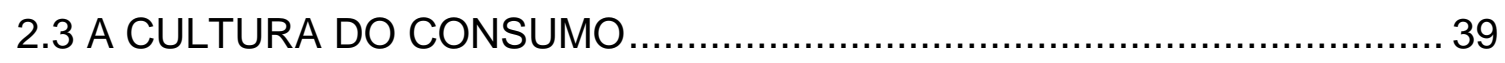

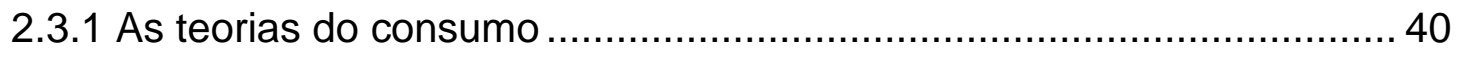

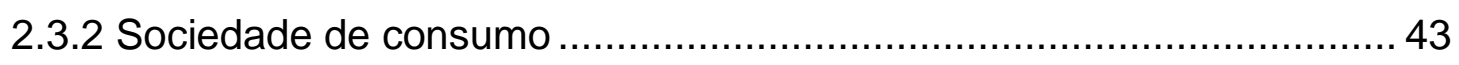

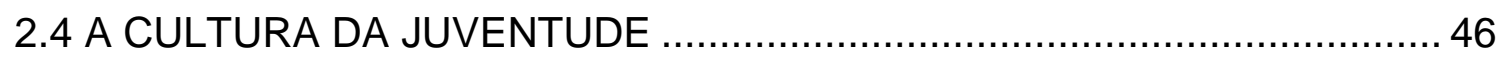

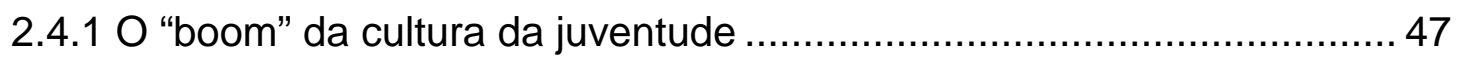

2.4.2 $\mathrm{Na}$ onda do rock: a consolidação da cultura jovem ............................. 51

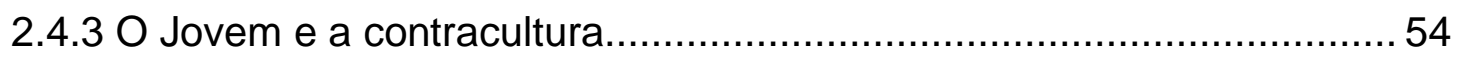

2.4.4 Indústria Cultural e Juventude no período autoritário ........................... 57 
2.4.5 A Cultura da Juventude e indústria cultural na contemporaneidade..... 61 CAPÍTULO III - CULTURA DA JUVENTUDE BRASILEIRA NAS DÉCADAS DE 1970 E 1980 70

3.1 JUVENTUDE BRASILEIRA, CONTRACULTURA E CONSUMO 70

3.1.1 Um pouco de Alegria, alegria no cenário brasileiro: contracultura e formação do Tropicalismo. 71

3.1.2 Anos 70: pra frente, Brasil! 87

3.1.3 Na época da juventude Mutante, ser Maluco era ser Beleza. 88

3.2 A JUVENTUDE NOS EMBALOS DE SÁBADO À NOITE 97

3.3 FAÇA VOCÊ MESMO: A HORA DO MOVIMENTO PUNK 100

3.4 ANOS 80: BRASIL DE PLANOS E DESENGANOS …........................... 108

3.5 UMA PAUSA PARA O POP. 111

3.6 O BROCK - MÚSICA, POLÍTICA E GERAÇÃO COCA-COLA. 115

3.6.1 Um som para a rapaziada: o início do Rock brasileiro dos anos 1980 115

3.6.2 Enquanto isso no Planalto Central: política e canção. 118

3.6.3 Rock na veia - a consolidação do BRock 123

CAPÍTULO IV - CULTURA DA JUVENTUDE: A ABORDAGEM DA VEJA E DA FOLHA DE SÃO PAULO. 132

4.1 Mídia impressa, juventude e Indústria Cultural 132

4.2 Um olhar através da Folha e da Veja 135

CAPÍTULO V - CONCLUSÃO 157

5.1 SUGESTÕES PARA NOVAS PESQUISAS 160 REFERÊNCIAS BIBLIOGRÁFICAS 161 


\section{CAPÍTULO I \\ INTRODUÇÃO}

O meu interesse em estudar a Cultura da Juventude parte da curiosidade em entender a relação entre a indústria cultural e os jovens, por serem eles, a parcela mais desejada pelas estratégias do Mercado, seja através da publicidade, seja pelo marketing, na contemporaneidade.

O período, as décadas de 1970 e 1980, tem, para mim, importância, tanto pela qualidade musical que marcou esse momento, através da formação da contracultura brasileira, do movimento punk e do BRock; quanto pela sedimentação do consumo jovem no nosso país, propiciado pela abertura econômica, pela influência musical internacional e pela consolidação de um mercado consumidor local.

O título do trabalho, "Cultura Lúdica da Juventude Brasileira", deixa margem a várias interpretações. Mas, em uma dissertação devemos encontrar um foco, um recorte para um panorama proposto. Cabe, então, definir o que é, para mim, o título colocado. Por cultura da juventude, entendo a formação de movimentos juvenis (o conceito de jovem será explicado no decorrer do trabalho). Esses movimentos se caracterizariam por sua dimensão e importância, seja cultural, seja política.

Quando falo em "lúdico", tento restringir esses movimentos juvenis a comportamentos ligados diretamente à cultura e o prazer, afastando-os da perspectiva política. Claro que é impossível se falar de tais fenômenos sem passar pela análise política, por isso mesmo, ela vai ser apontada, sempre que necessário, para contextualizar o objeto.

Ainda assim, a cultura da juventude continua uma temática extensa. Por conta disso, restringi aos seus aspectos mais marcantes, no caso, música e moda. Por moda, entendamos aqui, comportamento, atitude, além das vestimentas e adereços. Desde a sua incorporação aos jovens, a moda tem 
estreita relação com a música, já que esse é um dos canais que une grande parte da juventude mundial.

Desse modo, a cultura da juventude de que falo, é a cultura musical e de comportamento (moda) ligada aos jovens brasileiros. O período escolhido, como já falei, coincide com a formação dos movimentos culturais mais importantes para a história recente do país.

O subtítulo, "Rebeldia e consumo nas páginas da Veja e da Folha de São Paulo, tem relação com a consolidação desses movimentos juvenis como produtos culturais (de consumo).

A Cultura da juventude foi sempre marcada por essa dicotomia: consumo $\mathrm{x}$ rebeldia. O grande medo dos jovens que contestavam o sistema, no caso da contracultura, por exemplo, era o de serem englobados pelo sistema capitalista e, assim, perder todo o sentido de existência da manifestação.

A Revista Veja e o jornal Folha de São Paulo são o objeto de estudo prático, para entender como acontecia essa relação.

O Trabalho está dividido em quatro capítulos, incluindo esta Introdução. O segundo capítulo é dedicado às teorias sobre a indústria cultural e o consumo. Dando o embasamento para refletir sobre uma cultura da juventude. É complementado pela apresentação do surgimento dessa cultura, e sua relação direta com o rock e a contracultura.

O terceiro capítulo apresenta os movimentos culturais de juventude mais marcantes do período estudado. A saber: a contracultura (tropicalismo, Raul seixas e os mutantes - que fazem parte do tropicalismo, mas depois seguem um rumo diferenciado, mais comercial, até se converterem ao rock); disco-music (os embalos de sábado à noite e as Frenéticas); os ídolos internacionais (Michael Jackson e Madona); o movimento punk (internacional e brasileiro), que acabou incentivando o movimento seguinte; o BRock dos anos 80.

O quarto capítulo trata da pesquisa de campo nos dois veículos de comunicação escolhidos. 


\subsection{PROBLEMA}

Um movimento cultural de juventude pode viver sem a indústria cultural? É um questionamento interessante, pois sabemos que, por mais revolucionária que seja qualquer manifestação, ela pode ser mercantilizada.

Eu percebo que a Indústria Cultural participa dos movimentos e manifestações de juventude de três formas específicas:

- Mercantilizando manifestações culturais juvenis surgidas de forma espontânea. O movimento hippie, por exemplo, foi industrializado e, facilitou o crescimento da indústria fonográfica e da moda jovem;

- Criando ídolos ou movimentos juvenis como a disco-music, através do trabalho publicitário e de marketing;

- De forma simbiótica, quando a cultura juvenil utiliza da mídia, seja para disseminar seu discurso ou para o uso da moda como forma de criar laços de identidade.

Claro que esses pontos são complementares. Um movimento surgido de forma espontânea pode muito bem se utilizar da mídia mais tarde para disseminar suas mensagens, como foi o caso do tropicalismo.

A Indústria Cultural age através de sistemas harmônicos, aqui estão inclusos tanto a produção cultural, sua distribuição e os meios de comunicação. Por isso mesmo, tento entender como podemos perceber essa mercantilização das manifestações, por isso, a escolha dos meios de comunicação.

O problema principal do trabalho é entender o papel da comunicação midiática - no caso, as publicações impressas (Revista Veja e Jornal Folha de 
São Paulo) - na formação da cultura da juventude nas décadas de 1970 e 1980 no Brasil, com relação à sua abordagem sobre as manifestações; e se ela é influenciada diretamente pela mercantilização desses movimentos.

\subsection{OBJETIVOS}

O Objetivo principal desse trabalho é analisar a relação entre a cultura da juventude e o consumo. Mostrando a participação da indústria cultural para a sua consolidação.

Com a finalidade de atingir o objetivo geral proposto, foram definidos os seguintes objetivos específicos:

- Estudar as teorias sobre a indústria cultural e o consumo e verificar como a sociedade atual está estruturada;

- Entender como foi a formação de cultura da juventude nos Estados Unidos e verificar o surgimento do rock' $n$ 'roll como principal elemento de identificação juvenil;

- Verificar os principais movimentos e fenômenos de juventude no Brasil, tanto em suas perspectivas históricas, como em sua relação com a indústria cultural;

- Apresentar exemplos da abordagem dos meios de comunicação estudados sobre tais manifestações e relacioná-los ao processo de mercantilização dos mesmos.

\subsection{JUSTIFICATIVAS}


A realização desse trabalho se faz relevante em face aos seguintes aspectos:

- A juventude é um dos temas mais presentes nos estudos sociológicos da atualidade;

- A perspectiva apontada, com relação a constituição dos movimentos com base na indústria cultural, não se apresenta em muitos estudados da área, que priorizam os aspectos históricos;

- A análise levou em consideração um período extenso, de duas décadas, demonstrando a influência que cada período teve nos anos posteriores.

\subsection{METODOLOGIA}

A metodologia da pesquisa aplicada ao trabalho é composta dos seguintes pontos:

1.5.1 Embasamento teórico: Revisão Bibliográfica

Os autores utilizados foram os balizados na área das teorias da comunicação, sociologia e consumo. As conclusões lançadas por eles são, ainda hoje, base para estudos na área. Sobre a cultura jovem, utilizaram-se autores que discorreram historicamente sobre os movimentos. 
Entendo ser os meios de comunicação, participantes da indústria cultural e, por isso mesmo, se não diretamente, seguem as premissas mercadológicas balizadas por ela. No que tange à música e comportamento, normalmente o que aparece nas páginas dos jornais e revistas é o que já foi mercantilizado. Claro que a mídia escrita não segue os ditames do mercado, pois tem critérios próprios de noticiabilidade de um fato.

Mas se a importância de um movimento ou manifestação de juventude em geral, tem relação direta com o consumo, e por isso mesmo é um produto que atinge um grande número de pessoas, é imprescindível que tal assunto se torne pauta na mídia.

A escolha de meios escritos é baseada na facilidade de análise, já que vídeos da época são mais difíceis de serem encontrados e não possuem uma análise mais profunda como a mídia escrita. Além do mais, a revista e o jornal possuíam cadernos especiais sobre o tema.

A escolha da Revista Veja e do jornal Folha de São Paulo teve como critério a importância desses dois meios e o fato de existirem no período citado.

A coleta de dados da revista foi feita com base em todas as suas edições desde a tropicália até o final da década de 80 . Já no jornal, a pesquisa foi direcionada, através de palavras-chave que interessassem ao trabalho.

A análise dos dados foi feita com base nos autores estudados nos capítulos teóricos e no contexto histórico do período. Além disso, cruzamos as informações com fatos importantes relacionados com a indústria cultural, como a consolidação da indústria fonográfica, gravação de LP do artista, aparição em grande evento ou crescimento de outros setores importantes do Mercado Cultural.

Assim, apresentamos reportagens feitas sobre as manifestações e como a abordagem da Veja e da Folha mudaram com o tempo. Paralelamente, tais movimentos eram consolidados pela indústria cultural. 


\section{CAPÍTULO II \\ JUVENTUDE E INDÚSTRIA CULTURAL}

A cultura de massa se desenvolveu, em grande parte, através dos jovens. Neles, ela encontrou terreno fértil para a industrialização da produção cultural, para a massificação do público e a consolidação do capitalismo como sistema vigente no planeta.

O consumo virou a palavra de ordem da população. A máxima "Consumo, logo existo" pode ser a síntese do momento em que vivemos. Nossa contemporaneidade é marcada por relações mediadas pelos objetos, discurso esse, que ultrapassou o discurso dos sujeitos. Isto é, o homem se faz, não mais pelo seu pensamento ou habilidades, mas sim pelo que possui. E é através dos objetos (consumidos), que alcançamos posição social ou status.

Desse modo, o jovem atual precisa consumir para alcançar o pertencimento a um grupo social e, assim, conseguir se realizar como ser humano.

Para analisarmos essa complexa relação entre o jovem e a indústria cultural, é necessário que discutamos alguns conceitos básicos, relatados a seguir.

\subsection{POR UM CONCEITO DE JUVENTUDE}

Essa é a primeira dificuldade que encontraremos em nossa pesquisa: definir o que é juventude. Claro que essa definição é flexível e ganhou características diferentes em vários momentos da história humana. Ela é uma construção social e cultural, bem mais do que um período biológico em si, embora sendo encontrada entre dois momentos distintos da vida humana, que são a infância e a idade adulta. Representa um momento de transição e transformações 
psíquicas e físicas, mas mesmo assim, não conseguiríamos delimitar um espaço de tempo entre idades específicas para denominá-lo como juventude. Levi e Schmitt apontam para essa mesma reflexão ao dizer que:

Com efeito, ela se situa no interior das margens móveis entre a dependência infantil e a autonomia da idade adulta, naquele período de mudança e de inquietude em que se realizam as promessas da adolescência, entre a imaturidade sexual e a maturidade, entre a formação e o pleno florescimento das faculdades mentais, entre a falta e a aquisição de autoridade e poder. (Levi e Schmitt, 1996a, p. 8).

É, de fato, um período caótico e desordenado do ser humano, cheio de incertezas e dúvidas. "Essa época da vida não pode ser delimitada com clareza por quantificações demográficas nem por definições normativas". (Levi e Schmitt, 1996a, p. 8).

Importam-nos, no estudo sociológico, todas as facetas que envolvem o período em questão, analisado sempre por ser um "fato social intrinsecamente instável", que não segue as regras demográficas ou jurídicas, "com uma realidade cultural carregada de uma imensidão de valores e de usos simbólicos".

A Juventude deve ser vista como uma fase das tentativas, pela qual cada um tem que passar, pois as transformações sofridas durante esse período de maturação do corpo e da mente servirão de aprendizado para as decisões que nos esperam, futuramente, quando formos inseridos definitivamente na sociedade. Como afirmam Levi e Schmitt, a juventude é efetivamente o momento das tentativas sem futuro, das vocações ardentes, mas mutáveis, da busca e das aprendizagens incertas, sempre marcadas por uma alternância de êxitos e fracassos.

À juventude são instituídos vários papéis pela sociedade. Ela é composta de imagens que possui de si mesma e das representações atribuídas pelos adultos. Carregado de conteúdo simbólico, esse período ganha ares de conflito e resistência, não só porque ele acontece realmente na cabeça dos jovens, mas porque o é, também, balizado pelo pacto social. 
$\mathrm{Na}$ juventude concentra-se ainda um conjunto de imagens fortes, de modos de pensar, de representações de si própria e da sociedade como um todo. Estas imagens constituem um dos grandes campos de batalha do simbólico. A sociedade plasma de uma linguagem de jovens, atribui-Ihe caracteres e papéis, trata de impor-lhes regras e valores e constata com angústia os elementos de desagregação associados a esse período de mudança, os elementos de conflito e as resistências inseridas nos processos de integração e reprodução social. (Levi e Schmitt, 1996a, p. 11)

Com base no que foi apontado, analisaremos a juventude como fenômeno social e cultural e suas relações com o meio, especificamente, o establishment. Esse conceito de juventude será reforçado ainda mais com a sociedade de massa.

\subsection{CULTURA E SOCIEDADE DE MASSA}

Pensar em uma cultura da juventude só é possível dentro da perspectiva de uma sociedade de massa. O termo juventude é, sim, de difícil caracterização, mas falar de cultura dos jovens é estar em estreita relação com a rebeldia, o consumo musical e a moda. Essa cultura do jovem só pode ser pensada, então, a partir da cultura de massa com o auge em meados do século passado, enraizada no crescimento norte-americano pós-guerra e no surgimento de movimentos culturais como o rock'n'roll.

\subsubsection{Cultura}

No trabalho científico, os questionamentos sempre trazem novas perguntas e aqui uma não nos escaparia: o que é cultura, afinal? Palavra que permeia toda a nossa pesquisa e que engloba, decerto, tudo que compreende as relações humanas. 
Raymond Williams em sua obra Culture and Society, de 1958, aponta que o termo, em seu primeiro momento, denominava um processo: o de cultivo dos vegetais ou criação e reprodução de animais e, por extensão, cultura (cultivo ativo) da mente humana. No final do século XVIII, na Alemanha e Inglaterra, era relacionado à "configuração ou generalização do espírito" que informava o "modo de vida global" de determinado povo ${ }^{1}$.

T. S. Eliot caminha no mesmo sentido, quando diz que a cultura tem associações diferentes segundo tenhamos em mente o desenvolvimento de um indivíduo, de um grupo ou classe, ou de toda uma sociedade. Nenhuma delas pode ser isolada da outra. O sentido de cultura deve abarcar todas as dimensões sociais, pois "somente mediante uma superposição e partilha de interesses, graças à participação e à apreciação mútua, é que se pode alcançar a coesão necessária à cultura" (Eliot, 1988, p. 33).

Em Cultura e Sociedade, Raymond Williams acredita que a evolução da palavra cultura dá testemunho de numerosas reações, importantes e continuadas, e essas alterações de vida social, econômica e política, podem ser encaradas, em si mesmas, como um especial tipo de roteiro, que permite explorar a natureza dessas mesmas relações².

Portanto, não podemos separar a cultura de outras relações como a economia e a religião. A cultura engloba todos esses aspectos e se relaciona com eles, de modo dialético, transformando-se com o passar dos tempos e se traduzindo no sumo da sociedade.

Do mesmo modo, o ser humano é constituído do meio cultural onde foi socializado. Ele é um herdeiro de um longo processo acumulativo, que reflete $o$ conhecimento e a experiência adquiridas pelas numerosas gerações que o antecederam $^{3}$.

\footnotetext{
${ }^{1}$ Williams cita o trabalho de Kroeber e Kluckhohn (Culture: a critical Review of concepts and definitions) que estudaram os conceitos apontados. IN: William, 2000, p. 10.

${ }^{2} \mathrm{O}$ autor estuda cinco pontos básicos para entender a nossa moderna estrutura social: indústria, democracia, classe, arte e cultura. Esta última teria tido uma impressionante evolução e tem relação com as alterações sofridas pelas outras palavras. WILLIANS, 1969, p. 18.

${ }^{3}$ LARAIA, R. B. Cultura: um conceito antropológico. Rio de Janeiro: Jorge Zahar Editor, 1988.
} 
Se a cultura é um processo acumulativo de heranças sociais adquiridas, podemos imaginar que ela é como uma lente através da qual o homem vê o mundo. Assim, homens de culturas diferentes, usam lentes diversas ${ }^{4}$.

O fato de que o homem vê o mundo através de sua cultura tem como conseqüência a propensão em considerar o seu modo de vida como o mais correto e o mais natural. Tal tendência, denominada de etnocentrismo, é responsável em seus casos extremos pela ocorrência de numerosos conflitos sociais. (Laraia, 1988, p. 75).

Tais "lentes" diferenciam, caracterizam e hierarquizam as expressões culturais, relacionadas diretamente ao modo de produção da sociedade. Não podemos negar que o que sempre existiu foi uma forma de diferenciar "a cultura das elites" da "cultura do povo". O gosto estético é o que desponta primeiramente, mas somente nele não poderemos pautar essa distinção. O fator cultural, o reforço da ordem vigente e a vontade de aceitação social (por parte das classes mais pobres), manifestada através dos simulacros, podem ser norteadores dessa pesquisa.

Desejo chegar ao conceito de cultura de massa fazendo um histórico evolutivo das teorias relacionadas. Para isso, iremos comparar a cultura de massa com a cultura popular, e assim descobrir se são conceitos diversos ou complementares. Por fim, veremos como ocorre o seu "desenraizamento" para a sua massificação.

2.2.2 A alta cultura: do "melhor gosto" ao autoritarismo das elites.

De fato, é complexo buscar as características da alta cultura. Para isso, primeiramente, devemos pensar existir uma cultura superior. Dentro da perspectiva dos que aceitam sua existência, o que se nota é que essa cultura

\footnotetext{
${ }^{4}$ BENEDICT, R. O crisântemo e a espada. São Paulo: Perspectiva, 1972.
} 
sempre advém das classes mais altas. Mesmo que ela seja desprovida de pensamentos mercadológicos (e não é), ela nunca emanaria das classes mais pobres. Sua relação é objetiva e (ou) subjetiva. No seu caráter objetivo, podemos imaginar a diferenciação, como pressuposto básico. Já seu caráter subjetivo tem relação com termos como: prazer, gosto e valor estético. Sua análise será essencial para entendermos a satisfação obtida em contemplar uma obra de arte.

A alta cultura, com suas obras de artes, consegue instigar no ser humano uma sensação de liberdade. Um sentimento que leva a um prazer estético.

Os indivíduos não procuram a satisfação através do produto por sua aquisição e uso. Na verdade a satisfação nasce da expectativa, da procura do prazer, que se situa na imaginação. A motivação das pessoas em relação ao consumo, e ao juízo de valor, não é, portanto, simplesmente materialista. Elas precisam vivenciar na realidade os dramas agradáveis que já vivenciam em sua imaginação ${ }^{5}$.

A primeira característica do gosto é que ele é um valor. É a afirmação de uma diferença, pois ele se constitui em oposição a outros gostos.

O gosto é, portanto, portanto, a aptidão a tornar distinto e distintivo, o que significa que ele existe na e pela reação, na e pela presença.

O sujeito do gosto possui a paixão pela preferência, da predileção. Sua existência modal é dada por um querer-ser conjunto com um objeto classificado acima dos outros. O gosto de um defini-se pela aversão ao gosto de outros. Observa-se que, ao distinguir preferências, o gosto continua a operar com um princípio da exclusão, o que opõe o eu ao outro $^{6}$.

No texto Gostos de Classe e Estilos de Vida ${ }^{7}$, Pierre Bourdieu afirma que os estilos de vida têm influência direta no gosto das pessoas. "As práticas e as

\footnotetext{
${ }^{5}$ WABNER, p. Imaginários, Esferas culturais e Planejamento: Paula Wabner. http://www.assesc.com.br

${ }^{6}$ LANDOWSKI, Eric; FIORIN, José Luiz. O Gosto da gente, o gosto das coisas: abordagem semiótica. São Paulo: EDUC, 1997

${ }^{7}$ BOURDIEU, P. Sociologia. São Paulo: Ática, 1983.
} 
propriedades constituem uma expressão sistemática das condições de existência (aquilo que chamamos de estilo de vida) porque são o produto do mesmo operador prático, o habitus, sistema de disposições duráveis e transponíveis que exprime, sob a forma de preferências sistemáticas, as necessidades objetivas das quais ele é produto".

Dentro de sua realidade e a visão que possui de mundo, dentro de suas necessidades e a distância objetiva que possui dessas necessidades, o individuo constrói o seu gosto, que, de fato - utilizando a expressão de Bourdieu -, pertence ao seu habitus.

O exemplo de Featherstone (1995, p. 36) ilustra bem essa situação proposta por Bourdieu. De acordo com o autor, nas sociedades ocidentais, com o grande fluxo de mercadorias, é bem mais complexo fazer uma leitura do status do individuo portador dessas mercadorias. "É nesse contexto que se tornam importantes o gosto, o julgamento discriminador e o conhecimento ou capital cultural, que capacitam grupos ou categorias específicas para a compreensão e classificação adequada das mercadorias novas, bem como para a maneira de usá-las". Até o uso dos objetos depende do "habitus" de seu possuidor, para que ele seja diferenciador do gosto ou identificador de classe.

Mas como o gosto e o prazer estético podem definir as obras das elites como alta cultura ou uma cultura superior? Vimos que qualquer classe pode contemplar a obra e dela usufruir prazer estético. O que faz existir a obra de arte da alta cultura é um fator social.

$\mathrm{Na}$ história da humanidade, as idéias de uma época são as idéias dominantes de uma determinada época. O pensamento da elite, autoritário, impôs à camada mais pobre da população os padrões a serem vividos.

Neste caso, o autoritarismo das elites se manifestaria na necessidade de dissimular a divisão, vindo abater-se contra a cultura do povo para anulála, absorvendo-a numa universalidade abstrata, sempre necessária à dominação em uma sociedade fundada na luta de classes. Elite significaria precisamente elitismo e segregação, mas, ao mesmo tempo, afirmação de um padrão cultural único e tido como o melhor para todos os membros da sociedade. Salta aos olhos, então, o caráter paradoxal do autoritarismo 
das elites, visto que a idéia de padrão cultural único e melhor implica, por um lado, a imposição da mesma cultura para todos e, por outro lado, simultaneamente, a interdição do acesso a essa cultura "melhor" por parte de pelo menos uma das classes da sociedade. Assim, negando o direito à existência para a cultura do povo (como cultura menor, atrasada ou tradicional) e negando o direito à fruição da cultura "melhor" aos membros do povo, as elites surgem como autoritárias por essência. ${ }^{8}$

Esse padrão cultural imposto é tido como a alta cultura. A cultura do povo seria, na visão de autores como Marilena Chauí ${ }^{9}$, nada mais do que uma forma de revitalização de suas raízes e um modo de se contrapor a essa cultura superior. Isso em um primeiro momento. Quando acontece o surgimento das massas, essa elite (agora uma burguesia ascendente) vê na figura das populações mais pobres um modo de lucrar. Como donos dos meios de produção, instigando o consumo, eles fazem com que a população busque (em vão) participar dessa alta cultura. Como não possuem recursos para tal, surge na sociedade uma forma de pertencer essa "alta cultura", e acabam criando produtos que imitem os das classes mais ricas. Mais adiante veremos, no tópico sobre indústria cultural e cultura de massa, como surge essa nova sociedade.

Voltando a esse primeiro momento histórico, o povo é "descartado" de usufruir dessa alta cultura. Sendo assim, investe nas suas expressões, como reforço social e forma de combater a cultura da elite (claro que, de forma velada). A cultura do povo não é restrita ao povo, ela é um modo de sobrevivência em relação à alta cultura. A cultura popular, em parte, é o grito de uma classe que se julga excluída da "alta cultura". Não quero dizer com isso, que as expressões populares não tenham autonomia, pois elas o têm. As lendas, o discurso oral e a religiosidade são formas de reforçar a identidade de união do grupo. Essa união é incitada, também, pela vontade de crescimento social (cultural), podado pelas elites.

\footnotetext{
${ }^{8}$ CHAUÍ, M. Cultura e Democracia: o discurso competente e outras falas. São Paulo: Cortez, 1989. p. 40.

${ }^{9}$ Em Conformismo e Resistência, ela coloca que a cultura popular não pode somente nascer do povo e para o povo. Na música, por exemplo, as camadas médias urbanas é que fazem as canções escutadas no meio popular.
} 


\subsubsection{Cultura Popular}

Se tomarmos o senso comum para pensar a cultura popular, cairemos em erro, pois nesse âmbito ela é tida como o "fazer" desprovido de "saber" ${ }^{10}$. Claro que o trabalho científico deve se pautar na pesquisa, por isso mesmo, não diminuiremos o conceito a simplesmente o modo de vida do povo. Já que essa caracterização, como veremos adiante, pode ser identificada também com a cultura de massa.

A cultura popular não se resume (e muitas vezes não é relacionada) a receitas caseiras de remédios. Alguns pensam ser ela, algo relacionado somente ao folclore, à tradição. Em conseqüência disso, as sucessivas modificações por que necessariamente passaram esses objetos, concepções e práticas não podem ser compreendidas, senão como deturpadoras ou empobrecedoras.

Desse ponto de vista, a cultura popular surge como uma outra cultura que, por contraste ao saber culto dominante, apresenta-se como "totalidade" embora sendo, na verdade, construída através da justaposição de elementos residuais fragmentários considerados resistentes a um processo "natural" de deterioração.

Tentei, primeiramente, negar as concepções de cultura popular para, assim, conseguirmos conceituá-la. Para reforçar, recorremos a Raymond Williams (2000), que coloca a Cultura como algo mutável e que se constrói sobre uma rede de significações. A cultura é, então, resultado da soma de todos os outros discursos sociais, como a economia, o trabalho e a religião.

Com isso, já podemos afirmar que a cultura popular não pode ser algo estável. Ela não é somente caracterizada pelo fato de cultuar as tradições. $O$ folclore não é a cultura popular. Ela faz parte de um movimento da cultura popular para reviver e celebrar suas origens.

Se considerássemos a cultura popular como algo imutável, desistiríamos de pensar sobre as mudanças sociais ocorridas. As transformações são

\footnotetext{
${ }^{10}$ ARANTES, A. A. O que é cultura Popular? São Paulo: Brasiliense, 1981, p. 14.
} 
necessárias para a adaptação ao ambiente e para que ela possa sobreviver frente ao hibridismo cultural $^{11}$. Com essa reflexão, chegamos a uma primeira observação: a preservação das origens é um fato presente nas culturas populares. Se as tradições não são comemoradas e revividas dentro da cotidianidade, a cultura popular acaba por perder seus elementos formadores e acaba sendo descaracterizada pela cultura global $^{12}$.

A formação da identidade popular é uma reprodução simbólica das práticas e vivências compartilhadas pela comunidade, baseadas nas tradições e memórias coletivas, mediadas com os conteúdos modernos.

Além de tudo isso, o popular era um modo de se contrapor à elite. A cultura, também era um reflexo de conseguir aceitação ou de rejeitar essa alta classe. Como vemos em Bakhtin (1996), as festas populares da Idade Média se revestiam de personagens baseados nos personagens reais, e a pompa com que essas festas eram realizadas, remetiam à riqueza das elites, que não era compartilhada com a população mais pobre. O humor, o escárnio a chiste, eram formas de crítica popular que não fossem ofensivas ao sistema.

A cultura popular e alta cultura foram protagonistas dos debates sobre cultura até o século XIX, a partir daí surge um novo elemento - a massa - que será a base da maior parte dos estudos sobre comunicação nos séculos seguintes.

\subsubsection{O surgimento das massas}

\footnotetext{
${ }^{11}$ Para Nestor Garcia Canclini, vivemos no momento atual - de multiculturalidade - a vigência de valores globais dentro das culturas locais. E essas culturais locais tentam reforçar-se frente a este movimento.

12 Julgo que todas as culturas locais e, principalmente, dos países subdesenvolvidos (bombardeados pelos valores culturais globais), tentam reforçar suas tradições, como forma de identificação, de reforço dos laços que caracterizam o país. É a manutenção de uma espécie de "soberania cultural".
} 
O conceito de massa tem relação com as multidões que tomaram conta das cidades a partir do século XIX. Essas pessoas, que vinham na maioria das regiões interioranas, procuravam nas grandes metrópoles, oportunidades de enriquecimento, senão, pelo menos, sobrevivência.

De acordo com Tocquevillle ${ }^{13}$, "se antes se situavam fora, como turbas que ameaçavam com sua barbárie a 'sociedade', as massas encontram agora, dentro: dissolvendo o tecido das relações de poder, erodindo a cultura, desintegrando a velha ordem".

A massa surge, para os teóricos, como essa nova "casta" social. Essas pessoas que vivem aglomeradas nas cidades e que começam a formar uma nova cultura. Algo híbrido, entre as culturas populares e a alta cultura das elites, mas marcada por novos elementos, como o consumo.

Essa massa se transforma em mão-de-obra barata nas cidades e consumidora dos produtos que ela mesma produz. Nesse círculo vicioso, a massa acaba se tornando apática e vê nessa sociedade dominante, um modo de crescimento social através do trabalho.

A "massa" a qual nos referimos, é característica desse período histórico. A massificação que ocorrerá nos séculos seguintes através dos meios de comunicação estenderá esse conceito para uma grande parcela da população.

Uma das características sociais da grande cidade contemporânea, subproduto do desenvolvimento capitalista, é a presença constante das populações periféricas. Tais populações, se bem proletárias pelos ofícios que exercem, são fluidas desde o ponto de vista econômico, já que se encontram disponíveis para uma série de serviços. Impedidas de integrarem-se economicamente, permanecem à margem da cultura (e no extremo da sociedade civil). E, se periféricas ao capitalismo, são também periféricas ao proletariado, isto é, não geram formas culturais que a distingam pela peculiaridade de classe.

\footnotetext{
13 TOCQUEVILLE, A. De la democratié en Amérique. Paris, Gallimard, 1951 IN: MARTINBARBERO, J. Dos meios às mediações: cultura e hegemonia. Trad. Ronald Polito e Sergio Alcides. Rio de Janeiro. EDUFRJ, 2003, p. 57.
} 
Autores como Gustave Le Bon ${ }^{14}$ (autor de Psicologia das Multidões) se dedicaram a pensar na irracionalidade da massa. Para ele, do ponto de vista psicológico, a massa se caracterizava por indivíduos, os mais diferentes possíveis (seja no modo de vida ou no caráter), que possuam em seu inconsciente uma alma coletiva que os faz se comportar de maneira diferente do comportamento individual. Essa alma alcança uma espécie de regressão, um estado primitivo, despido de inibições e marcado pelas emoções e instintos, pondo essa massa à mercê de sugestões e do contágio.

Podemos pensar, então, que essa "cultura de massa" é algo degradante para o ser humano. Já que, se por um lado ela deturpa a cultura popular e destrói as tradições folclóricas, por outro, tenta se aproximar da cultura das elites, copiando as obras de arte, de maneira grotesca, fazendo com que ela perca a sua essência. Mas na cultura de massa, vemos transformações nunca dantes vistas ${ }^{15}$. A cultura de massa é a primeira a possibilitar a comunicação entre os diferentes estratos da sociedade. Uma sociedade com unidade cultural deve possuir uma circulação cultural. E na sociedade de massa isso foi atingido.

Mas ainda resta saber o que seria essa sociedade de massa. Vimos seu surgimento e suas características. Em suma, a cultura de massa é urbana, e nivela os indivíduos que a ela pertencem. Seus participantes não são uma classe ou "casta" específica. Por sua pouca importância política e econômica, são rostos parecidos em uma multidão de pessoas. Eles não compartilham da alta cultura e nem se prendem completamente à sua cultura tradicional. A massa é uma grande quantidade de indivíduos sem nome em busca de ascensão e reconhecimento social.

O nascimento dos meios de comunicação de massa trouxe uma nova perspectiva sobre o estudo desse fenômeno: a sua relação com as mídias e a possibilidade de influência dos meios sobre os indivíduos.

\footnotetext{
${ }^{14}$ LE BON, M. Psychologie des foules. $5^{\circ}$ ed., Paris: PUF, 1995.

${ }^{15}$ Autores como Alan Swingewood (e a Escola Progressista-Evolucionista) e Jésus Martin-Barbero acreditam ser esse um dos momentos mais democráticos da história da humanidade, onde todos, teoricamente, têm a possibilidade de adquirir quaisquer produtos. Claro que essa aquisição está limitada pela possibilidade financeira de cada indivíduo.
} 
2.2.5 A Indústria Cultural

$A$ ascensão do rádio ${ }^{16}$ no começo do século $X X$ trouxe à tona uma cultura voltada para as massas. Apesar de já existir a literatura de massa na Europa, só a partir da programação radiofônica podemos afirmar que um veículo de comunicação conseguiu atingir realmente a população.

A partir desse momento, os teóricos começaram a perceber o nascimento de um fenômeno que continua até os dias de hoje: a cultura de massa. Os primeiros estudos sobre a sociedade dessa época nasceram nos Estados Unidos. Vendo a possibilidade de utilizar as mensagens do rádio para "influenciar" o ouvinte, as pesquisas se direcionaram em uma "fórmula comunicativa", baseada nos conceitos behaviorianos de estímulo-resposta. Destes estudos, temos teorias como a Bala Mágica (ou Hipodérmica) e a teoria empírico-experimental, baseadas em modelos matemáticos da comunicação, que ressaltavam a onipotência do emissor da mensagem ${ }^{17}$.

O que podemos notar, realmente, é que os meios de comunicação auxiliaram na massificação do público. A homogeneização da sociedade deveria ser uma premissa, para que a mensagem pudesse ter uma recepção ainda maior. As massas englobavam tanto as camadas populares como as altas elites. As empresas de comunicação somadas à indústria do consumo tentavam transformar a população em uma massa una.

Os alemães foram os primeiros a pensar sobre essa estrutura macrossocial. Os teóricos da Escola de Frankfurt ${ }^{18}$ - em especial Theodor Adorno

\footnotetext{
${ }^{16}$ A invenção do italiano Guglielmo Marconi surgiu no final do século XIX, mas só ganhou respaldo no começo do século XX.

${ }^{17}$ A teoria da Bala Mágica era conhecida por este nome, por acreditar que a mensagem midiática atingia o receptor de forma direta, causando nele um estímulo. Um de seus maiores teóricos foi Harold Lasswell. Já a teoria empírica de campo, buscava saber quais respostas eram alcançadas a partir de estímulos dados.

${ }_{18}$ Os estudos desses autores nasceram em meio ao período nazista, onde o rádio teve papel decisivo para a disseminação do discurso ariano na população. Pensar a Indústria Cultural dentro de um período autoritário é diferente de pensá-la no âmbito da democracia, como veremos no decorrer do nosso trabalho
} 
e Max Horkheimer ${ }^{19}$ - cunharam o termo indústria cultural em substituição ao termo Cultura de Massa, já que esse último poderia ser confundido com algo que surgisse da população (do povo), sendo que, ao contrário, não é.

$\mathrm{Na}$ análise dos frankfurtianos, os procedimentos de massificação vão ser descritos não como substitutivos, mas como constitutivos da estrutura social atual. Ao invés de pensar a massificação no seu sentido em relação à cultura, Adorno e Horkheimer vão refletir sobre a racionalidade criada pelo sistema, com sua mercantilização da vida social - para poder pensar a massa como parte do processo de legitimação do capital.

Os mecanismos para alcançar essa legitimação, como forma de determinação do consumo e alienação, eram, principalmente, os meios de comunicação e a publicidade. Através da racionalidade técnica o homem é compelido a se ajustar ao sistema; uma racionalidade que ao invés de libertar, acaba cerceando, que não conscientiza, apenas domina.

\begin{abstract}
$\mathrm{Na}$ indústria cultural em todos os seus ramos fazem-se, mais ou menos segundo um plano, produtos adaptados ao consumo das massas e que em grande medida determinam esse consumo. Os diversos ramos assemelham-se quase sem lacuna para constituir um sistema. Isso, graças tanto aos meios atuais da técnica, quando à concentração econômica e administrativa. A indústria cultural é a integração deliberada, a partir do alto, de seus consumidores ${ }^{20}$.
\end{abstract}

A consciência do público é tomada e direcionada. O "pensar e refletir" a realidade macrossocial são atitudes que contrariam a lógica imposta pelo sistema. A vida privada ganha nova dimensão, agora preenchida pelas programações de televisão e pelas transmissões de rádio. A lógica do capital ganha tanto o espaço do trabalho quanto o do ócio, mercantilizando a vida e a sociedade.

\footnotetext{
${ }^{19}$ A análise desses dois teóricos é diferente da análise de outros autores da Escola de Frankfurt, como Walter Benjamin. Analisaremos sua obra, no que destoa daqueles, em um capítulo posterior. ${ }_{20}$ ADORNO, T. W. A Indústria Cultural. In: COHN, Gabriel (org.). Comunicação e Indústria Cultural. São Paulo: T.A. Queiroz, 1989.
} 
O meio de comunicação insere-se no âmbito do esquema abrangente da indústria cultural e, enquanto combinação de filme e rádio, leva adiante a tendência daquela, no sentido de cercar e capturar a consciência do público por todos os lados. A televisão permite aproximar-se da meta, que é ter de novo a totalidade do mundo sensível em uma imagem que alcança todos os órgãos, o sonho sem sonho; ao mesmo tempo, permite introduzir furtivamente na duplicata do mundo aquilo que se considera adequado ao real. Preenche-se a lacuna que ainda restava para a existência privada antes da indústria cultural, enquanto esta ainda não dominava a dimensão visível em todos os seus pontos ${ }^{21}$.

A lógica do sistema é vista, na visão dos frankfurtianos, por um lado, pela industrialização da cultura, que quebrou o paradigma do que ocorria na vida social e o que era produzido como obra de arte; e de outro, através da produção das coisas em junção com a produção de necessidades, resultando na racionalidade técnica que é a racionalidade da dominação.

Se pegarmos a obra de Theodor Adorno e dividirmos em pontos principais a sua reflexão sobre a Indústria Cultural, teremos três vertentes principais ${ }^{22}$ : o esquematismo, que engloba toda a produção cultural e condiciona o indivíduo; a transformação da cultura em indústria da diversão e; a dessublimação da arte.

O esquema (sistema) da indústria cultural tenta, de toda a forma, assimilar toda obra, atrofiando a capacidade reflexiva do sujeito. Na Dialética do Iluminismo, Adorno dá o jazz como exemplo. Nesse estilo musical, seu arranjador elimina tudo que possa atrapalhar a perfeição do seu estilo, estando a uniformização enraizada em sua produção.

O cinema é um exemplo clássico da atrofia do individuo. Para os frankfurtianos, os filmes passam de maneira muito rápida, impedindo o pensamento e reflexão do seu telespectador. Além disso, tudo já é dado nas imagens e se resume a uma percepção imediata, o telespectador não tem como

\footnotetext{
${ }^{21}$ ADORNO, T. Televisão, consciência e indústria cultural. IN: COHN, G. Comunicação e Indústria Cultural: Leituras de análise dos meios de comunicação na sociedade contemporânea e das manifestações da opinião pública, propaganda e cultura de massa nessa sociedade. São Paulo: Companhia Editora Nacional, 1977, p. 346.

${ }_{22}$ Essas divisões foram propostas por Jesus Martin-Barbero em seu livro Dos meios às Mediações, p. 77-83.
} 
desenvolver sua fantasia e torna-se "domesticado" pela realidade apresentada na tela.

Essa perspectiva dos teóricos vai acabar se convertendo num pessimismo com relação a essa sociedade midiatizada.

Para Adorno e Hokheimer, a Indústria Cultural funciona como um sistema, cujos setores são harmônicos em si e entre si, aí compreendidas as empresas diretamente produtoras de bens culturais (emissoras, diretoras, etc.), as produtoras de aparelhos e equipamentos (para emissoras ou para consumidores) e também os setores financeiros. Essa estrutura em forma de sistema se deve tanto aos meios que a técnica conseguiu obter atualmente, quanto à concentração econômica e administrativa; além de ser o resultado da descoberta da cultura como campo cheio de possibilidades para inversões de capital.

Como conseqüência, temos a estrutura adotada nos setores convencionais da indústria, marcados pela divisão do trabalho, trabalhadores separados dos meios produtivos e uma intensa busca tecnológica marcada pela colocação de máquinas no sistema produtivo. Os bens culturais seguem essa mesma diretriz. $\mathrm{O}$ que acontece é que a produção cultural também segue os parâmetros de lucratividade, com redução de gastos, aproveitamento do capital, barateamento da produção para diminuir o preço final, tudo isso incidindo diretamente no produto cultural. Apesar das exceções, nas obras individuais, isso é o que ocorreria normalmente.

Isto não quer dizer que não se conservam também formas de produção individual. Acontece que a ocorrência de uma manifestação qualquer de real valor artístico não autoriza que se acredite, só por ela, na possibilidade de redenção da indústria cultural. $\mathrm{Na}$ verdade, são casos isolados que a Indústria se permite, e pode se permitir essas exceções pois, assim, se ganha um bom álibi contra os críticos. No dizer de adorno e Hockheimer, todas as violações do exercício da profissão cometidas por Orson Wells the são perdoadas porque - incorreções calculadas - só fazem calcular a validade do tema ${ }^{23}$.

\footnotetext{
${ }^{23}$ MOREIRA, R. S. Teoria da Comunicação: ideologia e utopia, em busca de elementos teóricos para a leitura ideológica da indústria cultural. Petrópolis: Vozes, 1979.
} 
A segunda perspectiva de Adorno tem relação com a degradação da cultura em indústria da diversão. O capitalismo sempre arruma formas de sobrevivência: engloba as pequenas revoltas, os descontentamentos e continua fazendo a "máquina girar". Para que continue a crescer, o sistema necessita de produção e de consumo, preenchendo todos os espaços da vida cotidiana. A análise dos frankfurtianos sobre a experiência cotidiana leva as articulações entre o ócio e o trabalho. A unicidade e homogeneização buscadas pelo capitalismo se aplicam tanto nas tarefas diárias mecanizadas na organização do trabalho quanto no momento de descanso e diversão.

O momento ocioso do trabalho foi preenchido com o lazer, forma de adequação do sistema ao espaço de tempo entre as jornadas de trabalho. A mercantilização do ócio, transformado em consumo, movimentou novamente o capitalismo. A indústria cultural atua no espetáculo organizado em séries, no momento de lazer do indivíduo, com operações reguladas iguais às da lógica produtiva. A diversão funciona como forma de exploração diária. $\mathrm{O}$ individuo deve se encaixar e se conformar. Um espetáculo onde o sofrimento e a morte são banalizados e onde o conformismo impera, reprimindo a capacidade de rebelião.

O homem, cansado da rotina de trabalho chega em casa, liga a televisão e procura algo que possa assistir e que não espere dele nenhum tipo de análise. $O$ entretenimento vazio de reflexão é consumido de forma superficial e serve, somente, como preparação para o descanso. Dentro dessa perspectiva, os meios de comunicação de massa atuam a partir da lógica da Indústria, atrofiando o indivíduo. A realidade do aparelho começa a ser a sua própria realidade. Sobre o assunto, discorre Adorno:

A fronteira entre a realidade e a imagem torna-se atenuada para a consciência. A imagem é tomada como uma parcela da realidade, como um acessório da casa, que se adquiriu junto com o aparelho, cuja posse, além do mais, aumenta o prestígio com as crianças; Dificilmente será ir longe demais dizer que, reciprocamente, a realidade é olhada através dos olhos da TV, que o sentido furtivamente imprimido ao cotidiano volte a refletir-se nele ${ }^{24}$.

${ }^{24}$ ADORNO, T. Televisão, consciência e indústria cultural, p. 349. 
A terceira dimensão é a dessublimação da arte, marcada pela degradação da cultura. O sistema faz com que a vida seja banalizada e que arte seja positivizada.

A arte superior e cultura popular perdem suas características quando inseridas na cultura de massa.

Adorno aponta, nesse sentido, que na sociedade de massa, a alta cultura se vê frustrada no seu elemento sui generis ao perder sua aura e seu poder de incentivar a interpretação e fruição subjetiva, enquanto que a cultura popular se vê roubada no seu elemento rude de contestação e nos seus laços indentitários.

A grande questão é que obra de arte não pode ser vista fora do caráter mercantil. Se a sociedade de massa possibilitou sua industrialização e comercialização para várias pessoas, deturpando sua aura, como podemos analisar essa mesma aura quando o artista imprime na sua obra (digo a obra de arte não-produzida em série) a relação que ela tem com a mercantilização, já que é produto passível de ser consumido? Como analisa Martin-Babero, "como negação da funcionalidade social que é imposta através do mercado, acaba essencialmente ligada ao pressuposto da economia mercantil'. É uma contradição que deve ser assumida pelos artistas, pois a partir dela pode intentar sua independência. "De modo que contra toda a estética idealista temos de aceitar que arte obtém sua autonomia num movimento que a separa de ritualização, a torna mercadoria e a distancia da vida. (Martin-Barbero, 1999, p. 78).

A indústria cultural aparece, então, na visão de Adorno, para transformar a obra de arte em mercadoria. A visão desse último é criticada por Walter Benjamin, que aponta um novo conceito para a aura, que não o adorniano, relacionado à obra da alta cultura.

2.2.6 A Reprodutibilidade da Obra de arte 
O termo sui generis, utilizado por Adorno para definir a obra de arte na sua aura, sem os impositivos da Indústria Cultural, é utilizado aqui, não na sua raiz, mas sim, para compararmos os bens culturais que tentam se manter fora dessa massificação. Tanto a dita "alta cultura" como a "cultura popular" são construídas em cima de vários signos. Por isso, os fatores econômicos e sociais estão presentes em qualquer manifestação cultural. $O$ folclore, por exemplo, mesmo sendo expressão de uma tradição, acaba trazendo traços modernos, por que sua sobrevivência depende dos meios de comunicação. Ele perde sua faceta "sui generis", para se "vender" para a mídia. Ele só sobrevive por meio dela.

A alta cultura, que teoricamente seria desprovida desse desejo econômico, não sobreviveria se, o artista, não pudesse lucrar com sua obra.

Durante a pesquisa, tentamos definir os conceitos que circundam essa cultura de massa. Apesar de não concordar completamente, com os críticos vorazes a essa nova sociedade, temos que admitir que a cultura acaba perdendo um pouco de sua originalidade por ter que se adaptar ao campo econômico da indústria.

Alguns pontos são primordiais para confirmarmos essa transformação: a reprodutibilidade da obra de arte e o valor simbólico que trouxe à tona o simulacro social. Essa reprodução da obra sempre existiu, a industrialização trouxe, de certo modo, somente a rapidez ao processo.

\begin{abstract}
Mesmo por princípio, a obra de arte foi sempre suscetível de reprodução. $\mathrm{O}$ que uns homens haviam feito, outros podiam refazer. Em todas as épocas discípulos copiaram obras de arte a título de exercício; mestres reproduziram para assegurar-Ihes difusão; falsários as imitaram para assim obter um ganho material. As técnicas de reprodução, entretanto, são um fenômeno inteiramente novo, que nasceu e se desenvolveu no curso da história, por etapas sucessiva, separadas por grandes intervalos, mas num ritmo cada vez mais rápido. ${ }^{25}$
\end{abstract}

${ }^{25}$ BENJAMIN, W. A Obra de Arte na Época de Sua Reprodutibilidade Técnica. In: Costa Lima, Luiz (org.). Teoria da Cultura de Massa. Rio de Janeiro: Paz e Terra, 1978, p. 210. 
Benjamin acredita que a com a Reprodutibilidade da obra de arte, agora, as massas sentem mais próximas, com a ajuda das técnicas, até as coisas mais longínquas e mais sagradas. E esse "sentir", essa experiência, tem um conteúdo de exigências igualitárias que são a energia presente na massa.

O que acontece, segundo os frankfurtianos (Adorno e Horkheimer), é que quando ocorre a reprodução da obra de arte, ela perde o seu elemento de unicidade, sua presença única ligada à sua história, o que ele denomina como hi et nunc da obra de arte. As técnicas de reprodução industriais destruiriam essa "aura" da obra de arte.

Mas, ao levarmos isso em consideração, surge o seguinte questionamento: no mundo moderno da indústria cultural não se teria uma obra de arte? Se levarmos em consideração as teorias pessimistas da Escola de Frankfurt, talvez não.

$O$ caso mais interessante seria 0 do cinema. $O$ cinema nasceu nesse momento, e só existe por meio da indústria cultural. Pergunto-me se ele não seria considerado como arte. Volto novamente ao conceito de cultura, e ressalto que ela é algo mutável e que se transforma de acordo com as interações sociais existentes. Como poderíamos conceber uma publicidade completamente pautada na ética, se seu princípio é dar um valor simbólico a um bem qualquer? Devemos pensar o cinema como uma forma artística dentro de uma sociedade de massa.

A reprodução, hoje, se tornou muito mais inofensiva do que a supervalorização simbólica.

A aura da obra de arte pode sobreviver aos modismos impostos e à sua reprodução industrial. A música, só tornou-se tão conhecida no mundo, por ter sido reproduzida em grande escala. É claro que, a unicidade, dá à obra de arte, além de um valor estético, um valor comercial. Podemos tomar como exemplos, discos antigos, com poucas cópias, que se tornam tesouros nas mãos de colecionadores. 
Mas, mesmo com essa reprodução, ainda se mantêm a criatividade e o talento do artista. Sabemos que as imposições mercadológicas têm um papel maior na formação da obra, mas mesmo assim, ainda prevalece a vontade do artista. E essa vontade permanece em sua obra, mesmo que ela seja reproduzida várias vezes. Artistas como Chico Buarque, por exemplo, tentam se manter fora do circuito comercial para ter a liberdade de criação. Mas essa liberdade não impede que o discurso comercial esteja presente em suas músicas, só que ainda há um pouco da aura do objeto cultural presente.

Diferente da visão de Adorno, Benjamin vê nas massas e na técnica, a emancipação da obra de arte, libertada das amarras burguesas de diferenciação embasadas no gosto de classe.

Ele acredita que as massas são pautadas na aproximação. Adorno vê com pessimismo esse fenômeno, ao contrário de Benjamin, que vê no individuo a busca por uma consciência crítica e por uma transformação social pautada na conquista do sentido para o idêntico no mundo ${ }^{26}$.

Em busca desse sentido, que se expressa na técnica a vontade de macular a aura das obras de arte, erguidas no sentimento de distância, e que agora figuram em um novo tipo de existência, onde se tem acesso a elas. É o exemplo do que faz a fotografia.

A produção cultural industrializada é, desse modo, uma forma que está inserida na nossa sociedade e um processo sem volta. Através dela, criam-se novas relações sociais e a cultura ganha novas características.

\subsection{A CULTURA DO CONSUMO}

Como havia dito anteriormente, uma cultura da juventude pressupõe a existência de uma cultura de consumo. A indústria cultural trouxe à tona novas

\footnotetext{
${ }^{26}$ Martin-Barbero, Dos meios às mediações, p. 86.
} 
formas de sociabilidade, embaladas, principalmente pelo desejo de consumir. Analisar a questão do consumo é fundamental para que entendamos os mecanismos de formação de grupos e de movimentos juvenis.

\subsubsection{As teorias do consumo}

O Consumo é a mola-mestra do capitalismo. Se observarmos a noção de economia geral de Bataille (1988), veremos que a produção econômica não deveria ser associada à falta, mas ao excesso. Desse modo, a destruição tornase o objeto da produção, e o problema-chave passa a ser o que fazer com a "parte maldita", o excesso de energia traduzido num excesso de produtos e mercadorias, um processo de crescimento que alcança seus limites na entropia e na anomia. Para controlar efetivamente o crescimento e administrar o excedente, a única solução é canalizar isso na forma de jogos, carnavais, torneios de consumo e consumo do conspícuo ${ }^{27}$.

Para entender esse processo, podemos ter três perspectivas fundamentais: a primeira diz respeito à produção de mercadorias que, em crescimento, originou uma cultura de acumulação dos bens e dos locais de compra. "Isso resultou na proeminência cada vez maior do lazer e das atividades de consumo nas sociedades ocidentais contemporâneas". (Featherstone, 1995, p. 31).

Se essa possibilidade de adquirir produtos é estendida a todos, pode-se pensar que o consumo é, de fato, igualitário, mas para alguns pensadores, eles funcionam como um controle sedutor, reprimindo a organização das relações sociais.

A concepção sociológica diz respeito ao uso que as pessoas fazem dos bens. É um "jogo de soma zero", onde a satisfação e o status proporcionados pela mercadoria compensam o seu valor financeiro. As mercadorias serviriam para aumentar as distinções sociais, o que, de fato, traz prazer ao indivíduo.

${ }^{27}$ FEATHERSTONE, 1995, p. 42 
Existe também uma perspectiva emocional do indivíduo em relação ao objeto. "Há a questão dos prazeres emocionais do consumo, os sonhos e desejos celebrados no imaginário cultural consumista e em locais específicos de consumo que produzem diversos tipos de excitação física e prazeres estéticos". (Featherstone, 1995, p. 31).

Em uma sociedade em que os signos são superproduzidos e as imagens e simulações são a premissa da produção cultural, o individuo acaba perdendo a estabilidade do significado da vida. Isso tudo converge num movimento de estetização da realidade. Esse emaranhado de cores, imagens, signos, faz com que a população fique extremamente fascinada. O poder exercido leva a justaposições fora do sentido estável vivenciado pela massa.

Não podemos ser ingênuos e pensar que a população é dominada e obrigada a consumir. Claro que o individuo se satisfaz quando consome o bem material. A fruição do objeto não se delimita somente à sua forma, mas, principalmente, aos valores que ele carrega de ordem simbólica. As relações sociais são mediadas por esses objetos. Eles servem como símbolo de diferenciação e status, além de marcar a aceitação e pertencimento a determinado grupo.

Na segunda perspectiva teórica do consumo, verificamos a satisfação do individuo ao consumir. É nesse sentido que podemos designar o aspecto duplamente simbólico das mercadorias nas sociedades ocidentais contemporâneas: o simbolismo não se evidencia apenas no design e no imaginário embutido nos processos de produção e marketing; as associações simbólicas das mercadorias podem ser utilizadas e renegociadas para enfatizar diferenças de estilo de vida, demarcando as relações sociais. (Leiss ${ }^{28}, 1978$ apud Featherstone, 1995, p. 35).

A sociedade de massa possibilita o fim de algumas barreiras sociais, relacionadas principalmente ao consumo dos objetos. O acesso é maior, e os antigos laços são dissolvidos. Mas por outro lado, existe uma tendência contrária, restritiva, que atua como uma estratificação do consumo dos bens culturais.

${ }^{28}$ LEISS, W. The limits to Satisfaction. Londres. Marion Boyars, 1978. 
Como existe uma oferta constante e um sentido de massificação de cada produto cultural - buscando, assim, um maior número de consumidores -, o caráter de diferenciação ressaltado pelo bem produzido acaba ruindo. Desse modo, as classes mais altas tentam, a todo custo, investir em mais bens que restabeleçam essa distinção (isso pode ser pensado não somente nesse contexto, mas também, na diferenciação de quaisquer grupos).

Recorremos à Bourdieu, que enfatiza a dificuldade de reconhecer os grupos sociais pelos objetos utilizados. Essa dificuldade para identificar o "capital cultural" é uma tendência da nossa sociedade, o que obriga cada vez mais aos indivíduos, imprimir nos modos, jeito de vestir, se portar (entre outros) toda a diferenciação cultural que é signo de status para o seu grupo.

\begin{abstract}
Um dos problemas gerados pela dinâmica da cultura de consumo é que a "inflação' é reintroduzida constantemente, à medida em que bens escassos ou limitados passam a ser comercializados para uma população maior ou sofrem uma queda no mercado, provocando uma corrida social para conservar as distinções reconhecíveis. A satisfação depende da posse ou do consumo de bens culturais sancionados e legítimos (portanto, escassos ou limitados). (Featherstone, 1995, p. 126).
\end{abstract}

Uma das armas é o investimento intelectual, o estudo, para diferenciar-se das outras classes, tanto que, na sociedade atual, a escolarização é caminho certo a ser seguido para a classe média. Como a diferenciação não pode ser feita através do produto, já que este pode ser conseguido por qualquer um - e quando não, obtêm-se o seu simulacro -, a informação se torna o "produto" para significar status.

A cotidianidade da sociedade de massa gera uma progressiva desvalorização dos estilos dominantes. Os gostos estão à mercê do mercado por conta da popularização do consumo. Para vários teóricos, a massificação causa essa desvalorização, tanto na cultura de elite quanto na cultura popular ${ }^{29}$.

${ }^{29}$ A Esse respeito, observar o tópico sobre Indústria Cultural. 
A terceira perspectiva abrange aspectos psicológicos do consumo, como a associação de sonhos e imagens. O consumo resgatou imagens e ilusões esquecidas do indivíduo, o que Walter Benjamin ${ }^{30}$ chamou de Alegorias. "As novas lojas de departamentos e galerias, que surgiram em Parias e posteriormente em outras grandes cidades a partir da metade do século XIX, eram efetivamente mundos de sonhos".

Nesse caso, o termo é utilizado na para assinalar a unidade ou coerência de uma mensagem de código duplo que está oculta - como nas alegorias tradicionais -, mas para mostrar como se dissolve um significado estável e hierarquicamente ordenado; a alegoria aponta apenas para fragmentos caleidoscópios que resistem a qualquer noção coerente sobre o que ela representa. (Featherstone, 1995, p. 44).

A sociedade de massa trouxe uma nova fase na cultura das cidades ocidentais. Transformaram-se em centros de consumo e de experiências, medidas pela produção cultural e de bens, claro, através do entretenimento conseguido na Indústria Cultural.

As pessoas vivem em um eterno jogo, que tem como bases os signos e valores referenciais, constituindo uma trama urbana, onde existem papéis e onde os objetos desempenham discursos, sendo extensão do homem e significante do individuo. A sociedade de consumo celebra valores superficiais que são marcados pela moda e estilo. Valores esses, voláteis, que mudam de acordo com as tendências e não podem ser classificações estanques das estratificações sociais.

O individualismo dá lugar às tribos, formadas com base na empatia de seus membros e marcada pela representação e fugacidade ${ }^{31}$. Essas características -e as outras apresentadas acima - formam uma sociedade estruturada no consumo

\subsubsection{Sociedade de consumo}

\footnotetext{
${ }^{30}$ BENJAMIN, W. Das Passagen-Werk. Oganização de R. Tiedermann. Frankfurt, Suhrkamp, 1982.

${ }^{31}$ Sobre o Neo-Tribalismo (e as teorias de Maffesoli), falaremos especificamente dentro da cultura da juventude em um capítulo posterior.
} 
O padrão de uma sociedade de grupos fixos começa a ruir a partir do momento em que todo possuem acesso aos produtos. Nas palavras de Featherstone, esse aparente movimento em direção a uma cultura baseada em profusão de imagens e proliferação de imagens - que não podem ser estabilizadas de maneira definitiva, nem hierarquizadas em um sistema correlacionado com divisões sociais fixas -, estaria sugerindo também a irrelevância das divisões sociais e, em ultima análise, o fim do social enquanto ponto de referência importante.

O efeito disso seria o fim de uma relação determinista de cultura, com classificações estanques e valores consolidados, para uma cultura baseada na representação.

Nesse contexto, a sociedade associa a aquisição de bens com a felicidade. Ter determinado produto é premissa para a satisfação pessoal, por conta, principalmente do pertencimento.

Nas classes mais baixas - nas favelas, por exemplo - aparelhos eletrônicos como televisores de tela plana e DVD's nunca faltam em uma sala de estar. As necessidades básicas são colocadas de lado em relação àquelas de consumo, pois estas últimas trazem a falsa sensação de prosperidade, pertencimento, valorização do EU e igualdade com as classes mais altas.

\begin{abstract}
A força ideológica da noção de felicidade não deriva da inclinação natural de cada indivíduo para a realizar por si mesmo. Advém-lhe historicamente, do fato de que o mito da felicidade é aquele que recolhe e encarna, nas sociedades modernas, o mito da Igualdade. Toda a virulência política e sociológica, com que este mito se encontra lastrado, desde a Revolução Industrial e as Revoluções do século XIX, foi transferida para a felicidade. Que a Felicidade ostente, à primeira vista, semelhante significado e função, induz conseqüências importantes quanto ao respectivo conteúdo: Para ser o veículo do mito igualitário, é preciso que a Felicidade seja mensurável. ${ }^{32}$
\end{abstract}

Desse modo, o prazer estético que causava a felicidade, se torna "falso" na nossa sociedade, já que a própria noção de felicidade está deturpada. O indivíduo

${ }^{32}$ BAUDRILLARD, J. A Sociedade de Consumo. Lisboa: Elfos, Edições 70, 1975, p. 68. 
não busca essa sentimentalidade, porque, está ela contaminada pelo desejo social implícito de igualdade.

O homem busca a satisfação, que julga encontrar na aquisição do bem, mas essa compra não fará com que ele obtenha nenhum prazer, digo aqui, o prazer natural de obtenção da coisa desejada; o prazer é mediado pelas relações de consumo implícitas na sociedade capitalista.

\begin{abstract}
Possuir o objeto da alta cultura é um modo de alcançar um status social. "Cada um sabe-se, no fundo, se é que não se sente, julgado pelos seus objetos, julgado segundo os seus objetos, e cada um, no fundo, se submete a este juízo, mesmo que seja pela negação. Trata-se aqui de algo mais que o imperativo de conformidade vindo do grupo restrito ou do de mobilidade ascendente vindo da sociedade global; trata-se de uma ordem em que cada indivíduo ou grupo não pode deixar de se ordenar no próprio movimento que o faz existir socialmente". ${ }^{33}$
\end{abstract}

Todo produto cultural da sociedade de massa nasce com essa premissa: de se tornar signo distintivo. Os objetos, inclusive as obras de arte não são criados pela maioria. A informação contida neles - isto é, o conhecimento necessário para traduzi-lo, é possuído somente por uma determinada classe, fazendo com que esse seja mais um ponto de diferenciação.

Todos os objetos, inclusive as obras de arte, tornam-se signos distintivos. "Os criadores "populares", por detrás da sua piedosa ladainha (educar o gosto do público), promovem a sua estratégia inconsciente: os belos objetos modernos, estilizados, são sutilmente criados (a despeito de toda a boa-fé contrária) para não serem compreendidos pela maioria, pelos menos imediatamente: a sua função social é, em primeiro lugar, a de serem signos distintivos, objetos que distinguirão aqueles que os distinguem. Os outros nem se quer verão". ${ }^{34}$

Para Baudrillard ${ }^{35}$ (1975), a sociedade de massa é marcada pelo fim do valor de uso original da mercadoria, trocado pelo signo, que só pode ser

${ }^{33}$ BAUDRILLARD, J. Para uma Economia Política do Signo. Trad. Aníbal Alves. Rio de Janeiro: Elfos.; Editora Lisboa, Edições 70, 1995. p. 22.

${ }^{34}$ BAUDRILLARD, J. idem, p. 32.

${ }^{35}$ Apud Featherstone, 1995, p. 122. 
entendido arbitrariamente por sua posição num sistema auto-referenciado de significantes. Por isso, não podemos entender o consumo através de um valor de uso. Os bens devem ser vistos através de um consumo de signos.

A cultura de consumo pressupõe que as mercadorias e suas estruturas de produção são essenciais para que compreendamos a sociedade atual. Segundo Featherstone, isso envolve um foco duplo: em primeiro lugar, na dimensão cultural da economia, a simbolização e o uso de bens materiais como "comunicadores", não apenas como utilidades; em segundo lugar, na economia dos bens culturais, os princípios de mercado - oferta, demanda, acumulação de capital, competição e monopolização que operam dentro da esfera dos estilos de vida, bens culturais e mercadorias.

Se pegarmos como exemplo a televisão, perceberemos que as informações passadas por ela afetam nosso sentido de realidade. Tudo que é colocado é podado, editado e ganha ares ficcionais. Não temos como usar a informação ali obtida como referencial do mundo, mas somos bombardeados diariamente por seus conteúdos, tomando tudo aquilo como verdade.

A cultura da representação, imposta tanto pelos meios de comunicação como pela própria sociedade - no âmbito de suas relações -, triunfa em mundo "simulacional" (nas palavras de Featherstone), onde as imagens e signos criaram uma pseudo-realidade, abolindo nossa percepção sobre o real e o imaginário.

É o corolário da estetização da vida e da realidade. Como o social e o real perderam valor, os indivíduos começam uma busca desenfreada por relações que sejam mais reais, por valores que sejam mais enraizados. Isso causa fenômenos como o neotribalismo, uma busca insana por uma vida que não seja mediada e permeada por imagens da realidade, desembocando em movimentos, subgrupos e novas culturas (como as criadas pelos jovens).

\subsection{A CULTURA DA JUVENTUDE}


Os elementos principais para a formação de uma cultura da juventude estavam aí: uma sociedade de massa e jovens com uma maior consciência e propensão para o consumo. Claro que fatores políticos e ideológicos também serão marcantes, por isso mesmo, detalharemos esse aspecto adiante. Mas no seu primeiro momento, essa cultura surge com a cara da sociedade de consumo e os Estados Unidos é o berço desse processo.

\subsubsection{O "boom" da cultura da juventude}

O teenager (adolescente) é o termo que melhor codifica o nascimento de uma nova fase para os estudos sobre a juventude. A cultura jovem é identificada, em primeiro plano, com esse estrato social. De acordo com os teóricos, o processo que implica na construção da adolescência, como fase em si, atingiu a sua maturidade plena logo após a Segunda Guerra Mundial.

Nesse período, a tônica dos debates de sociedade recaía sobre as crianças, adultos e os jovens combatentes que estavam na guerra. No ano de 1945, um artigo de Elliot Cohen, publicado no New York Times, usou o termo teenager como parte da linguagem corrente. Somente na década de 1950, o termo ganhou respaldo, através do debate sobre suas implicações. $O$ ano de 1955 é o marco, por conta da geração nascida entre 1943 e 1940. "É significativo que obras-símbolo para aquela época tenham sido escritas na primeira metade da década de 1940, só tenham ficado famosas uma década depois. Basta dar dois exemplos: On the Road, escrito por Kerouac em 1941, tendo como título original The beat generation, foi recusado pelos editores até 1957, quando foi publicado" (Levi e Schmitt, 1996b, p. 352).

O contexto do período, marca a consolidação econômica americana. Com o crescimento do consumo, no pós-guerra, era imperioso criar nas pessoas a necessidade de consumir cada vez mais. 
Segundo Packard (1968, p. 10), no período pós-guerra, a quantidade de mercadorias e serviços que um homem pode produzir em uma área aumentou cerca de $3 \%$ a cada ano. Essa produção aumentada só pode ser absorvida se cada cidadão consumir mais ou se houver um maior numero de cidadãos. Caso contrário, haverá menos trabalho.

A balança pendia para o lado da produção. Se o país não consumisse 0 que the era produzido, a economia não iria girar. As empresas teriam que produzir menos, o que acarretaria em demissões em massa e estagnação econômica.

Não existia outra opção a não ser a de incentivar as pessoas a comprarem mais, absorvendo assim, o excedente de bens produzidos. Packard (1968, p. 20) afirma que o grande desafio era desenvolver um público que tivesse apetite tão voraz quanto suas máquinas. O problema central consistia em estimular maior desejo e criar novas necessidades.

Um autor americano chamado Victor Lebow (apud Packard, 1968, p. 23) dizia em 1950: "nossa economia enormemente produtiva exige que façamos do consumo nosso modo de vida, que transformemos a compra e uso de mercadorias em rituais, que procuremos nossas satisfações espirituais". Completaria, ao dizer que "as satisfações de nosso ego, no consumo... precisamos ter as coisas consumidas, queimadas, gastas, substituídas e jogadas fora, em ritmo sempre crescente".

A idéia desse consumo desenfreado se baseava na obsolescência. $O$ produto deveria ser descartado o mais rápido possível. Desse modo, o cidadão compraria um novo produto e impulsionaria o setor produtivo. Produtos que durassem muito não combinavam com esse perfil consumista que os empresários e o Estado americano desejavam.

Em ímpeto consumista foi também absorvido pelas crianças nascidas no período pós-guerra, conhecidas como baby boomers ${ }^{36}$.

\footnotetext{
${ }^{36}$ O termo designa as crianças nascidas depois de 1945 nos Estados Unidos. Havia um sentido patriótico de ocupação do país, ao mesmo tempo em que a conjuntura econômica permitia e incentivava a procriação. Com o país necessitando do aumento da população existia uma verdadeira Ética da procriação, termo usado por vários autores para descrever o sentimento
} 
Essas crianças nasceram junto com a televisão, no final da década de 1940, e não demorou muito tempo para que os publicitários percebessem a grande oportunidade de mercado que esse público oferecia.

A sociedade americana cresceu centrada no televisor, e os baby boomers consumiam o que the era colocado de maneira voraz. A entrada na escola só ocorria, em média, aos seis anos, então, eles eram atingidos por esse conteúdo televisivo, sem possuir ainda, barreiras psicológicas para mediar tais mensagens.

A união dessas crianças com a televisão se transformou no caminho para o crescimento da publicidade. Se de um lado, temos um grande número de pequenos consumidores, com pais dispostos a atenderem seus desejos, de outro, temos a grande audiência e um aumento do potencial persuasivo dos meios de comunicação de massa.

A Televisão e a publicidade, ao se associarem, criaram muitos dos fenômenos que caracterizam toda essa geração, como as modas.

Contrariamente às tendências, que são fenômenos de origem atitudinal, normalmente de longa gestação antes de sua exteriorização, as "modas" invadiam as ruas, casas, escolas, todos os espaços, de um dia para o outro, e de repente, sem nenhuma explicação, desapareciam. Como exemplos das "modas" que marcaram a geração "baby boomer" podem ser apontadas as roupas e acessórios de caubói, de David Crackett, os bambolês, patins, Barbies, entre outras menos contagiantes. (Figueira Neto, 1996, p. 30).

Os teenagers da década de 1950 eram diferentes dos adolescentes e jovens dos períodos anteriores. Eram em maior em número e, principalmente, em autoconsciência. Os primeiros jovens de uma geração privilegiada, que se uniam em seus grupos de forma coesa, tinham vários interesses em comum e laços identitários muito fortes.

A cultura urbana era o local onde emergiam esses adolescentes. Seu universo, cheio de signos e representações era centralizado no High School, como uma obrigação social, e até cívica, o casamento precoce e a geração de filhos. 
freqüentada por jovens de todas as classes sociais, além disso, seus papéis sociais tinham uma rígida distinção por idade.

O tempo dos jovens não era passado com os adultos. Se não estavam na escola, estavam em seus empregos. "Contava, sobretudo o peso diferente da interação: não era mais aquela entre pais e filhos ou entre estudantes e professores que ofereciam significativos ganhos sociais, mas sim a interação entre pares" 37 .

Isto é, o jovem começou a deixar o espaço familiar e ganhou as ruas. Ele construiu novos espaços urbanos como a lanchonete ou o parque. A interação entre jovens começou a se tornar muito maior e daí, começam a surgir os grupos e subgrupos.

Isso era incentivado pela própria família, que enxergava na sociedade de consumo, papéis essenciais para a sobrevivência do jovem, sempre aliados à popularidade ou satisfações frívolas.

Os teóricos desse momento, embasados em textos sociológicos genéricos sobre os jovens, apontavam que o cidadão americano era orientado a viver em uma dependência da aprovação, com base em ideais abstratos balizados pela sociedade.

Dentre esses textos, sem dúvida $A$ Multidão Solitária, obra coletiva sobre a mudança do caráter americano - cujo autor principal era David Riesman segundo a qual a sociedade americana passara a produzir indivíduos heterodirecionados (em vez de voltados para a tradição ou, como antes nos Estados Unidos, autocentrados). Em conseqüência, ensina às crianças que a unicidade da personalidade não se baseava mais nas competências, em habilidades ou no desenvolvimento de desejos próprios e ideais abstratos, mas na satisfação das expectativas dos outros, portanto, na dependência da aprovação: de tal modo, os indivíduos aprendiam a ser orientados - numa sociedade caracterizada pela abundância econômica, pelo burocratismo, pela permissividade - para a fruição passiva, o consumo, o conformismo ${ }^{38}$.

\footnotetext{
${ }^{37}$ LEVI E SCHMITT, 1996b, p. 354-355.

${ }^{38}$ Idem, p. 356.
} 
Quando os "boomers" chegaram à adolescência, acontecem novos fenômenos e novas estratégias de consumo para atingir esse público, que, ao contrário das crianças, tinha expectativas, rebeldias, angústias e tristezas, exteriorizadas através, principalmente, do rock and roll. ${ }^{39}$

O ritmo não surgiu com eles, nasceu dos "guetos" negros americanos, mas rapidamente virou sucesso. Essas músicas foram adaptadas pelo mercado para os "boomers". Eles foram a audiência e presenciaram o crescimento do rock.

O contexto para o crescimento do consumo jovem ocorreu nos Estados Unidos, mas se espalhou para o mundo inteiro. E a juventude, através de sua moda ou de sua música foi alvo do mercado, que queria expandir o consumo de bens culturais.

Como vimos anteriormente, a obsolescência criada na mente de seus consumidores é o modo mais eficaz de aumentar o consumo. A juventude, por seu ímpeto de novidades, e a procura incessante por identificação nos grupos sociais, foi, sem dúvida, a mais bombardeada por essas estratégias de consumo.

O jovem, além de ter papel preponderante nas decisões de consumo dentro de casa, era um ávido consumidor da moda e do que era produzido. A questão do consumo se tornara essencial para a sua sociabilidade e elemento de agregação ou desagregação das "tribos".

2.4.2 Na onda do rock: a consolidação da cultura jovem

O rock'n'roll é, de fato, a primeira grande revolução estética no gosto da juventude. Esse movimento foi importante não somente como estilo musical, mas também comportamental e de consumo. O marco desse fenômeno é o

${ }^{39}$ De acordo com Waldenyr Caldas, o rock é uma mistura de influências, principalmente do ragtime, do jazz (be-pop), da country music, do velho blues, da western music, do rhythm and blues e das canções gospel. A expressão em si foi criada Poe Alan Fred, DJ americano em 1951. Cultura da Juventude nos de 1950 e 1960, p. 4. 
lançamento de Rock Around The Clock, gravado por "Bill Haley e seus Cometas" no ano de 1954. O movimento foi seguido por músicos com Chuck Berry, Little Richards, Elvis Presley, entre outros.

Esses cantores consolidavam os anseios da juventude da época, principalmente no que dizia respeito à liberdade sexual e a contestação do poder patriarcal. Tanto que a sociedade conservadora em um primeiro momento reage de maneira truculenta ao advento do rock, vendo nesse estilo musical a deturpação da moral do jovem ${ }^{40}$.

Por conta do modo de dançar - onde as moças rodopiavam suas saias e fazia coreografias, no mínimo, eróticas, além das danças dos cantores como Elvis Presley -, a Igreja condenou o movimento por demonstrar a expressividade do jovem através do sexo.

De acordo com Waldenyr Caldas, a repressão da sexualidade não é a melhor atitude a ser tomada pelo Estado, por ser este um fato inerente ao ser humano. Os aparelhos ideológicos do Estado (Família e Escola, por exemplo) tomo emprestado a expressão de Louis Althusser - tentaram reprimir em vão o crescimento do rock nos Estados Unidos.

O lançamento do filme Rebel Without a Cause (Juventude Transviada, aqui no Brasil), estrelado por James Dean, marca o nascimento da expressão Rebeldes sem Causa, que designava a atitude dos jovens dessa época. Eles estavam cansados dos velhos padrões americanos, marcados por um sistema conservador em relação aos filhos, principalmente no que diz respeito à sexualidade. $O$ rock foi o caminho encontrado para demonstrar suas frustrações e instrumento de mudança no país.

Os filmes da época marcavam o inconformismo, a inquietude e a rebeldia dos jovens contra o establishment. Eles não aceitavam mais os valores sociais ainda arraigados a uma sociedade pré-Segunda Guerra Mundial. A modernização do Estado se fez sentir na indústria, na produção econômica em geral, na tecnologia e especialmente nos meios de comunicação (...) Embalados pela força selvagem do rock, os jovens começariam a se libertar dos velhos padrões de conduta aos quais

${ }^{40}$ CALDAS, W. Cultura da Juventude nos de 1950 e 1960, p. 4. 
estavam submetidos e acostumados. A repressão sexual, por exemplo, vai perder força e boa parte da juventude já não sublimará, como antes, os seus desejos sexuais ${ }^{41}$.

O que não podemos esquecer é que a juventude do rock'n'roll não era politizada e nem culta. Estava alheia a problemas externos e não tinha opinião formada com relação às guerras nas quais seu país se envolvia. O que marca realmente essa juventude é o consumo, a explosão dos bens materiais e simbólicos que faziam parte do jogo de representação para o pertencimento dos grupos sociais.

O jovem gostava de vestir sua calça jeans, andar de carrões "rabo de peixe", usar topetes e jaquetas, freqüentar as lanchonetes e lugares da moda.

No Brasil, o rock'n'roll vai chegar no final da década de 1950. "Aí sim, principalmente em São Paulo, já podemos falar e notar a presença de uma cultura cosmopolita, que tão bem expressa o estilo de vida no meio urbano-industrial' (Caldas, 1998, p. 27). Apesar de ainda possuir os elementos rústicos, formadores do ethos social brasileiro, o nosso país foi "invadido" pela cultura de massa americana e aos pouco foi se adaptando ao modo de vida global. Isso ocorreu, graças a abertura para o capital estrangeiro ocorrida no governo de Juscelino Kubitschek.

Assim, podemos perceber que o Brasil não entrou de imediato na cultura de consumo. Como explica Waldenyr Caldas, não podemos falar propriamente de uma cultura de massa no Brasil, pelo menos até o surgimento da televisão em 1950. Até mesmo o apogeu da Era do Rádio, não se caracteriza como acontecimento de massa. Só após esse período que temos uma consolidação do consumo.

Com sua chegada ao país, muitos intelectuais e artistas nacionais julgavam que o rock poderia descaracterizar nossa música popular. Vimos, no decorrer dos anos que isso não aconteceu. O samba continuou a existir - ao contrário do que previam os mais catastróficos - e novos ritmos nasceram, influenciados pelo

${ }^{41}$ Idem, p. 11 
fenômeno americano, como a Jovem Guarda e a batida pop do Tropicalismo. Claro que não podemos ser ingênuos a ponto de pensar que o rock não trouxe toda uma carga da cultura americana, principalmente relacionada ao consumo.

\begin{abstract}
É evidente que, com o rock'n'roll, chega também toda uma carga de cultura de massa americana. Padrões de comportamento que se evidenciaram no vestuário, na projeção do futuro de cada jovem, nas relações sociais, na gastronomia, entre outras coisas de significada importância. (...) Rigorosamente, não houve grande transformação na nossa música, em face do aparecimento do rock. Já faz cinqüenta anos que este ritmo chegou ao Brasil e nossa cultura popular, especialmente a música, não sofreu alterações estéticas que a descaracterizasse ${ }^{42}$.
\end{abstract}

Para Tupã Gomes Corrêa, por ser um argumento de reflexão, o rock representa uma conquista de si mesmo para quem se identifica com ele. Assim, toda a exploração comercial que se produz a partir dele passa a ser uma espécie de armadilha, pois, se os elementos de identidade com ele se colocam como apelos de consumo, ele acaba se transformando num artifício irreal de indução, mistificado por sentidos além dos seus. Com isso, acaba também servindo para trair todos os que se sentem envolvidos por ele $^{43}$.

De fato, o inconformismo da juventude americana ia ao encontro do que era apregoado pelo rock, mas esse era um produto cultural e, como tal na sociedade de massa, vinha carregado de valores que não eram percebidos pelos jovens, escondidos na estetização da obra.

\title{
2.4.3 O Jovem e a contracultura
}

Apesar da busca pela liberdade e o combate à repressão sexual serem manifestações importantes, não vimos nesse período uma práxis política desses jovens. Até porque, ela necessita de uma reflexão teórica sobre toda a sociedade.

\footnotetext{
${ }^{42}$ Ibdem, 26-27.

${ }^{43}$ Tupã Gomes Corrêa e Pelópidas Cypriano de Oliveira. A rockmania na cultura jovem, p. 149.
} 
A grande maioria da juventude não era engajada politicamente, o mesmo ocorria no Brasil na década de 1950. Claro que o exemplo brasileiro deve ser bem explicitado, já que aqui, nunca tivemos - até esse momento histórico - períodos democráticos longos, impossibilitando atos reivindicatórios por modelos democráticos, que só poderiam ser vivenciados na experiência.

A partir de meados da década de 60 , vemos uma mudança nessa postura da cultura da juventude, marcada principalmente pelo movimento denominado contracultura.

Para Carlos Alberto Messeder Pereira ${ }^{44}$, a contracultura tratava-se, de fato, de um movimento de contestação que colocava frontalmente em xeque a cultura oficial, prezada e defendida pelo sistema e pelo establischment. Diante dessa cultura privilegiada e valorizada, a contracultura se encontrava efetivamente do outro lado das "barricadas". A afirmação e a sobrevivência de uma parecia significar a negação e morte da outra. E agora, amplificada e difundida pelos meios de comunicação de massa, a recusa radical da juventude ganhava a cena com grande alarde e assumia ares de uma verdadeira contracultura.

Waldenyr Caldas complementa que a forma de organização social, o excessivo controle do Estado sobre o indivíduo, a racionalidade científica, o modelo de Universidade, o excesso de burocracia, entre tantas outras instituições, deveriam ser refutadas. Um outro ponto importante é que ela se valia, às vezes, de explicações místicas ${ }^{45}$.

Podemos encontrar duas vertentes no conceito do movimento, segundo Carlos Alberto Messeder Pereira. De um lado temos uma perspectiva que engloba os movimentos de rebelião da juventude, como o rock e o movimento hippie, além das drogas e orientalismo. Todos esses com uma busca de uma nova realidade como ponto comum.

A outra vertente é baseada no movimento de oposição, contestação e de enfrentamento da ordem vigente.

\footnotetext{
${ }^{44}$ CALDAS, 2008, p. 73.

${ }^{45}$ Idem, p. 61.
} 
A segunda vertente a que me refiro sobre o conceito de contracultura, envolve até mesmo a idéia de recusa, de oposição e de crítica à cultura oficial. Em outros termos, significa uma atitude contra a cultura estabelecida pelo Estado. Os valores sociais, morais, sexuais, as relações pessoais, profissionais, sempre muito protocolares e superficiais, tudo isso deveria ser criticado e recusado pelos adeptos da contracultura ${ }^{46}$

Seus integrantes não eram nem os jovens da Elite, esperançosos por uma melhor divisão da riqueza mundial, nem os desprovidos financeiramente, mas sim, de jovens de classe média, estudantes em sua maioria, que rejeitavam essa cultura oficial.

As universidades, americanas e européias, foram o centro das discussões sobre o movimento. A partir das leituras da obra de Karl Marx e de Hebert Marcuse (Eros e Civilização), os jovens decidiram colocar em prática aquilo que era apregoado nos livros.

Claro que cada país teve um jeito diferente de colocar esses preceitos em prática. A juventude mais intelectualizada preconizava justiça social e mudanças no paradigma econômico, como na Europa, onde os jovens tinham um "legado esquerdista institucionalizado". Na guerra do Vietnã, essa postura da juventude européia contrastava com as manifestações americanas, que apregoavam "paz e amor" e as garantias democráticas de grupos minoritários (como o gay Power e o Black Power).

O caso brasileiro é bem diferente da Europa e dos Estados Unidos, já que aqui não possuíamos uma democracia consolidada. Na década de $1960^{47}$ período mais importante da contracultura - vivíamos momentos complicados no campo político.

A juventude brasileira intelectualizada, antes mesmo do golpe militar, já exigia do governo reformas de base. Como aponta Waldenyr Caldas, o objetivo era fortalecer as instituições democráticas que, uma vez mais, corriam sérios

\footnotetext{
${ }^{46}$ Ibdem, p. 62.

47 "Essa década se iniciaria com a eleição do Presidente Jânio Quadros, que permaneceu apenas sete meses no poder (...) O vice-presidente João Goulart assume a presidência e em 1964, é deposto por um golpe militar. Daí em diante, até 1985, vivenciamos um terrível período de autoritarismo imposto pelos militares". Cultura da Juventude nas décadas de 1950 e 1960, p. 69.
} 
riscos durante o governo de João Goulart. Os militares já haviam demonstrado sua insatisfação e o país caminhava para o autoritarismo.

No ano de 1961, a União Nacional do Estudantes criaria o CPC - Centro popular de Cultura. A intenção era democratizar a cultura popular brasileira. Os CPC atuavam junto a operários e pessoas carentes.

No plano do consumo, as músicas de protesto, de autores como Chico Buarque e Caetano Veloso - no Brasil -, e de Bob Dylan - no cenário internacional, invadiram as rádios. $O$ estilo hippie também ganhou adeptos no país, criando uma produção cultural alternativa (no sentido de não pertencer aos conglomerados), mas que acabou se esvaindo de seu elemento principal formador. "Os desdobramentos do comércio hippie nos Estados Unidos, de certo modo, comprometeriam em boa parte toda aquela filosofia de recusa à ordem estabelecida (Caldas, 1998, p. 77)."

Nascia na Inglaterra os Beatles, que imprimiam novo estilo ao rock'n'roll. Em meio ao universo beat, composto por jovens de classe média baixa e pobres, que freqüentavam pubs e ambientes underground, o grupo ganhou o mundo.

O consumo de drogas também cresceu a década de 1960, marcado pelo movimento psicodélico.

No Brasil, os movimentos se sentiam pressionados pelo Estado e as manifestações da juventude (de caráter político) foram proibidas a partir de Ato Institucional número 5, no ano de 1968.

\subsubsection{Indústria Cultural e Juventude no período autoritário}

Sabemos que no período autoritário o fator ideológico da cultura é reforçado. Com o advento dos meios de comunicação de massa, esses governos ganharam um aliado para disseminar suas idéias e cooptar as massas. 
A primeira coisa a se rebater, é que as mídias não possuem um poder manipulador poderoso sobre as massas. $O$ que foi poderoso, no caso alemão, por exemplo, foi a mensagem repassada. O sentimento nacional, o xenofobismo, o rancor com as perdas de territórios, já se misturavam no sentimento do povo alemão que se sentia injustiçado. As multidões possuem um poder alienador gigantesco. As pessoas, movidas passionalmente em grandes grupos, acabam se deixando levar pela vontade da massa.

O Reinch trabalhou esse sentimento de maneira persuasiva e inteligente, utilizando a propaganda de guerra, os filmes contra judeus e as falsas informações.

No que tange aos regimes autoritários que dominaram principalmente a América Latina, Espanha e Portugal durante grande parte do século $\mathrm{XX}$, temos alguns pontos importantes sobre o seu surgimento: o subdesenvolvimento e as perspectivas de mudança esperadas pelo povo, além do medo dos regimes socialistas.

Mas como se comporta a indústria cultural no momento autoritário? Primeiro, devemos notar que os períodos autoritários modernos foram marcados pela fase de desenvolvimento desses países. Então, vemos um crescimento da indústria cultural. Em segundo plano, observamos a manutenção da censura nos meios de comunicação de massa, com um rígido controle. Em terceiro lugar, o desejo de divulgação das ideologias ditatoriais através desses meios.

A consolidação da cultura da juventude já havia sido feita na década de 50 . Os movimentos nacionais dos jovens se consolidaram a partir do rock internacional e das traduções de grandes bandas. Na década de 60, paralelamente aos movimentos de contracultura, nasce a Jovem Guarda, de carona nos ritmos norte-americanos, com uma música contagiante que pregava um estilo de vida baseado na intensidade, nas festas, nos carros e na velocidade. Enquanto o primeiro era observado de forma cuidadosa pelos setores conservadores da sociedade e pelos militares, o segundo ia ao encontro de uma indústria de consumo crescente. 
Para nós, o mais importante é salientar os aspectos teóricos envolvidos na produção cultural, quando vigiada por um regime autoritário.

As expressões culturais sempre primaram pela democracia, já que a liberdade, como sentimento obtido também pelo prazer estético, não pode ser manipulada por um poder centralizador.

Os artistas, assim, produzem suas obras contaminadas de um desejo de liberdade e de combate à censura. A arte se torna, então, expressão potencialmente perigosa, o que faz com que os artistas busquem colocar em suas obras, o mais implicitamente possível, mensagens que cultuem a tão sonhada liberdade de expressão.

A carga ideológica de uma música, por exemplo, desse período, é tamanha. Para nós, no momento atual pode não representar muita coisa, mas se buscarmos historicamente as origens da gravação, veremos todo um sentimento compartilhado por grande parte da população em um produto cultural.

A indústria cultural continua a produção de maneira a não contrariar os preceitos ditatoriais, por isso, os produtos perdem um pouco se sua aura (além da já perdida com sua reprodutibilidade técnica), principalmente quando podada pelos órgãos de repressão. Qualquer produto cultural poderia ser potencialmente perigoso ou considerado "contra os preceitos do Estado". O controle, se não era exercido de forma direta - pela censura -, o era através do pacto social, do discurso estatal disseminado na sociedade, que contagiava todas as produções culturais.

Após 1968, se iniciou a fase da repressão e do estrangulamento da criatividade da cultura brasileira. A partir daí, filmes nacionais e estrangeiros, livros, programas de televisão e rádio, peças de teatro, músicas, jornais e revistas passaram a ser violentamente censurados. A entrada maciça de capitais estrangeiros, estimulada pelo Governo Militar através de empréstimos e de aplicação em indústrias, gerou até a década de 70 uma rápida expansão de um mercado consumidor, premissa básica para os interesses das oligarquias nacionais. Este período de falsa euforia, explorado sob o título de "milagre 
brasileiro", provocou a miragem da ascensão das classes sociais e as diferentes distorções na visão de mundo da sociedade brasileira

\begin{abstract}
Simultaneamente, a propaganda estimulava 0 apetite das massas para 0 consumo e os vários meios de comunicação as conduzia à alienação e satisfação pessoal. Conjugado a esse processo, o governo militar adotou uma política de importação de tecnologia, sobretudo nos setores da industria bélica e das comunicações. A melhor expressão cultural desse período foi a televisão. Com o uso dos satélites e do sistema de microondas, ela passou a cobrir todo o território brasileiro, transmitindo programas nacionais e internacionais, através das redes. Nesse período, iniciaram-se as transmissões em cores. É o momento do domínio quase absoluto da TV Globo, não só pela extensão da sua rede transmissora, como também pela técnica desenvolvida e pelas novas linhas de programação, com destaque para as telenovelas e telejornais. ${ }^{48}$
\end{abstract}

Após o Golpe de 1964, ocorreu a consolidação de uma poderosa indústria cultural em bases não só capitalistas, mas cada vez mais monopolistas de Estado. O progresso atingiu mais duramente os grandes meios de comunicação de massa como a televisão, a grande imprensa, a produção de discos e o cinema. Este processo de monopolização da Indústria Cultural gerou uma forte expansão qualitativa dos chamados bens culturais, o que, antes de mais nada, serviu para ocultar o fenômeno do vazio cultural, que é obviamente um fenômeno de natureza qualitativa.

Mesmo sendo baixos em orçamentos derivados pelo Estado à área cultural, existia um projeto cultural no Brasil, que era o projeto de mercado, era a indústria cultural. Assim, além de ter consentido a implantação da indústria cultural no Brasil, o Estado possibilitou e incentivou o seu surgimento por este motivo, os investimentos na cultura por parte do Estado não foram baixos, mas sim, direcionados a setores de bens culturais que interessavam ao Governo e que não o contestavam.

$\mathrm{Na}$ verdade, falar em cultura brasileira é falar em relações de poder. As relações entre cultura e Estado são antigas no Brasil. Se tomarmos um exemplo relativamente recente, o dos anos 30 , veremos que como

\footnotetext{
${ }^{48}$ PINTO, V. B. N. Cultura: A sociedade brasileira na virada do século. IN: Comunicação e artes em tempo de mudança: Brasil, 1966-1991. São Paulo. ECA/USP. Sesc, 1991. p. 33-34.
} 
advento do Estado Novo, o aparelho estatal encontra-se associado à expansão da rede das instituições culturais (criação do serviço Nacional de Teatro), à criação de cursos de ensino superior, e também à elaboração de uma ideologia de cultura brasileira. ${ }^{49}$

A cultura brasileira era reforçada nos produtos culturais da época. Nesse período, começa a se consolidar um dos nossos maiores bens culturais: a telenovela. Além de ser um retrato do cotidiano, construía representações do cidadão brasileiro, reforçando os laços identitários e apresentando novos elementos sociais.

A interação dos jovens com os produtos culturais mudou no decorrer do tempo. A telenovela, por exemplo, era uma programação voltada para donas-decasa, mas, a partir da década de 1970 ganhou contornos sociais mais fortes, saindo das limitações do melodrama, para retratos mais fiéis da sociedade no momento.

Isso tudo foi impulsionado por uma nova visão de sociedade, que era acompanhada também pelos jovens.

2.4.5 A Cultura da Juventude e indústria cultural na contemporaneidade

O fenômeno Cultura da Juventude tem uma relação direta com o consumo (como pudemos verificar durante o Capítulo I). Ao refletir sobre esse processo, veremos duas vertentes distintas, mas complementares: de um lado, uma indústria cultural que encontra nos movimentos juvenis a possibilidade de mercantilização de sua cultura, através da moda e; de outro, a formação de grupos e tribos que, através do consumo, criam laços de identidade e pertencimento, isto é, através dos objetos, eles se tornam mais próximos, com base em um movimento de tribalização ${ }^{50}$.

\footnotetext{
${ }^{49}$ ORTIZ, R. Cultura brasileira e identidade nacional. São Paulo-Brasil: Brasiliense, 1985, p. 80.

${ }^{50}$ Vide Michel Maffesoli. O Tempo das Tribos.
} 
A dialética entre a Indústria e os jovens cria essa cultura da juventude, e suas características podem ser encontradas tanto nos movimentos de contracultura, que tinham um caráter mais ideológico, quanto em movimentos juvenis urbanos, como os punks.

A indústria cultural tem como uma de suas especializações a Moda. Podemos encará-la dentro do contexto da comunicação, através do sentido semiológico, já que ela é uma linguagem que possui vários símbolos e significados, assim como o vestuário, que é visto como uma linguagem articulada $^{51}$, pois através das roupas e adereços, conseguimos nos comunicar.

Mas é claro que a moda ganha um papel diferenciado em meados do século passado, por conta da sedimentação da sociedade contemporânea atual, baseada no consumo. Na contemporaneidade, os objetos consumidos deveriam ter vida útil pequena, para que assim, a produção nunca "parasse de girar", efeito esse, que é uma das bases para a Indústria da Moda sobreviver.

No que tange à juventude, como nos afirma o sociológo Tupã Gomes Corrêa ${ }^{52}$, "o movimento hippie foi praticamente o primeiro a produzir grandes transformações de posturas, as quais por natureza alojaram-se, por assim dizer, na moda". Apesar do discurso e atitudes desse grupo de jovens representantes da contracultura, o que primeiro despontava como elemento de identificação era o seu vestuário, marcado pelas roupas, adornos e também penteados.

O estilo hippie ganhou o mundo, principalmente, através de artistas do cinema e da música (especialmente do rock). 0 condutor desse processo foi o consumo. O movimento foi englobado por processos de industrialização de seu vestuário, de mercantilização da ideologia da contracultura e de fetichização da juventude.

E claro, ao ser todo o conjunto assumido como um sistema orientador de produtos a ser consumidos, foi, por um lado, perdendo sentido enquanto

\footnotetext{
${ }^{51}$ Somente a partir do século XIX, a moda, ganha as características que conhecemos. Em um primeiro momento valorizava as características nacionais e a personalidade do indivíduo. Vide: BARTHES, R. Sistema da moda.
} 
código da resistência e, por outro, sendo todo ele disseminado como um estilo de vida a ser consumido por um número cada vez maior de pessoas, as quais, certamente, não estariam tão preocupadas com a resistência aos padrões que levavam à violência (além dos relacionados especificamente com a guerra), quanto principalmente com os objetos que desejavam consumir. (Corrêia, 1991, p. 20).

A indústria da moda foi a ponte entre o símbolo de resistência do movimento jovem e o consumo praticado a partir da contracultura. Mas não podemos generalizar. Existiam, sim, jovens engajados, que participavam da resistência ao establishiment e aderiram àquele modo de ver o mundo e criavam, assim, laços identitários de grupo. O pertencimento era buscado através dos ideais apregoados pelo movimento hippie.

Acontece que, existiam jovens que não possuíam esses mesmos ideais e encontravam no vestuário hippie apenas uma fruição consumista. Estes, sim, eram alvos da Indústria Cultural.

Isto é, alguém que, embora se vestisse, usasse cabelos ou portasse os adornos necessários da maior parte dos adeptos do movimento, nada mais era do que apenas um consumidor de modismo. Modismo esse que se construiu sobre atitudes de pessoas contrárias ao sistema vigente. (Corrêia, 1991, p. 20).

$\mathrm{Na}$ verdade, os movimentos juvenis que surgiram a partir do século passado tiveram como um de seus elementos caracterizadores, a moda ou o vestuário. Por isso mesmo, devemos pensar a moda não só como um bem de consumo. Pois ela tanto é veículo de rompimento com os valores estabelecidos (como no caso da contracultura e do movimento punk), como veículo de disseminação desse rompimento, que será transformado, posteriormente, em padrão cultural.

Assim, com esse processo de transformação do vestuário, que o levou a ser mais do que um simples produto, para se tornar signo e representação, alcançamos o conceito de moda. "E esta, assim concebida, vem fortemente marcada como produto típico de uma indústria que transcende a manufatura, 
para, segundo suas características, confundir-se com o produto cultural'. (Corrêia, 1991, p. 21).

A moda cria sistemas próprios de edição. Através dessa sistemática ela corresponde à veiculação de idéias entre os seus usuários, bem como à repulsa social.

Elementos como a idade, o sexo, a classificação econômica e o local onde vivem, não são atributos qualitativos impressos na roupa que se veste ou no estilo que se utiliza.

O que determina o uso desse produto é a identidade que o jovem pretende ter.

Esse comportamento juvenil, muitas vezes, tem relação direta com seus ídolos. No rock, principalmente, o estilo que o cantor ou banda possui influi no estilo que o jovem utiliza. Ensejando, desse modo, uma moda, que vai se transformar em produto, através do consumo em larga escala.

\begin{abstract}
Se levarmos em conta que o uso das calças compridas por mulheres, por exemplo, foi realçado pela ambientação do rock and roll dos anos $50 \mathrm{e}$, a partir dele, generalizado; que a moda dos cabelos compridos aconteceu ao som do rock dos anos 60; que o biquíni e a minissaia, de igual modo, também surgiram nesse mesmo embalo, seremos forçados a admitir a existência de uma hipótese, no mínimo de relação entre tais mudanças e adoções desse gênero de música popular. $E$ tudo isso sem falar no hábito internacionalizado de se usar jeans, esse tecido que, a partir dos anos 1950 trocou o campo pela cidade, deixando de ser o pano das roupas dos caipiras do interior dos Estados Unidos, para se tornar o símbolo de um verdadeiro estilo de vida. Estilo este que, a partir da roupa, passou a sugerir uma postura informal e tipicamente jovem. ${ }^{53}$
\end{abstract}

A postura jovem tinha relação direta com a música, e ela, em meados do século passado, possuía um apelo social muito forte, nascendo com fonte de rebeldia e contestação, vide o exemplo do rock. Mas para alguns, esse ritmo teria perdido a sua "aura", após os movimentos contestatórios.

${ }^{53}$ CORREIA, T, 1991, p. 30-31. 
Não sejamos maniqueístas. O rock não se tornou somente ferramenta para o consumo nas décadas seguintes aos movimentos de contracultura. Continuou a buscar novos estilos, se adaptando a todos os tipos de manifestação. A transição ocasionada pela influência do consumo na cultura hippie foi lenta e gradual. Teve seus frutos somente na década posterior, como a retomada da visão ecológica e o crescimento da medicina natural. É um processo lento, o de mercantilização, mas ele, de fato, acontece, sem necessariamente ser, de todo, prejudicial ao movimento.

No começo desse subtítulo, falei de duas vertentes no estudo dessa relação entre a juventude e o consumo. Primeiramente, a visão de cima para baixo, impulsionada pela "sede" da indústria em mercantilizar o gosto jovem. Mas existe uma outra visão: a de ser o consumo, forma de legitimar esses movimentos, forma de criar laços de identidade, de fortalecer suas características e de se contrapor a outras manifestações.

Comprar um disco e uma calça jeans rasgada não se resume simplesmente ao ato de adquirir o produto. É uma aquisição que está além da necessidade e representa o acionamento de um código, que implica em juntar-se a outros indivíduos que possuem esses mesmos produtos, para inserir-se no universo que esse bem cultural representa.

\begin{abstract}
Eis porque a roupa usada por alguém pode ser definida para além de seu aspecto material, refletindo o significado de um conteúdo comum a muitas pessoas. Significado este que também pode estar associado, por assim dizer, ao conteúdo de outras peças, as quais muitas vezes podem não ser necessariamente materiais - como um determinado tipo de corte de cabelo, por exemplo, que, por seu lado, pode remeter a um certo intérprete do rock, cujos discos se associam a todo um universo musical, marcadamente jovem. A partir dessa relação, tudo o que se produz e é colocado à venda em um mercado assinalado por semelhanças equivalentes passa a ser objeto de consumo, segundo as equivalências materiais e, principalmente, de conteúdo. Pois os códigos que são comuns aos consumidores desse tipo de conteúdo, além de revelarem um sentido comum entre os produtos em circulação, servem também para o estabelecimento de uma equivalência cultural entre eles. ${ }^{54}$ (Correia, 1991, p. 35).
\end{abstract}

${ }^{54}$ CORRÊIA, 1991, p. 35. 
A juventude na contemporaneidade é formada por um mix de estilos, subculturas, tribos, unidas principalmente pela comunicação de massa e o cultivo de uma imagem exterior - representação -, "tornando-se mais um fim em si mesmo, designando mais a especificidade de um grupo juvenil em relação aos outros do que um veiculo de rebeldia; definem-se pelo uso específico da moda e cultura de massa, que por uma linha ideológica e política ${ }^{55 " . ~ A ~ c u l t u r a ~ d e ~ c o n s u m o ~}$ possibilita ao jovem essa mudança rápida e repentina de estilos, de identificação, recriando as relações sociais de grupo.

\begin{abstract}
Dessa forma, se tomarmos a atribuição de ser jovem a partir de determinações como vínculo à escola e perfil de consumo significa: mudar, experimentar emoções, estar potencialmente aberto ao mundo, ao consumo, às novidades que o mercado oferece. Assim, estes personagens juvenis expressivos da cena urbana realizam criações culturais e inovações, a partir da base "espetacularizada" fornecida pela gigantesca maquinaria cultural que capta, reproduz e divulga essas criações $^{56}$.
\end{abstract}

Esse agrupamento de jovens seria uma tendência visualizada na sociedade de massa na atualidade. Maffesoli acredita que existe hoje um "grupismo". Ele difere do gregarismo ${ }^{57}$ no fato de que cada membro do grupo, conscientemente ou não, se esforça, sobretudo, para servir ao interesse do grupo, ao invés de, simplesmente, procurar refúgio nele ${ }^{58}$.

O autor utiliza dois termos que julga importante na contemporaneidade: a estética (o sentir em comum) e a ética (laço coletivo). As sociedades de massa, para ele, possuem uma preocupação com um presente vivido coletivamente. Poderíamos pensar ser a sociedade atual individualista, ocasionada pela forma mecanicista do trabalho, baseada numa racionalidade técnica, mas ao contrário, ela está permeada por laços de empatia, formando uma estrutura complexa e orgânica.

\footnotetext{
${ }^{55}$ SANTOS, R. A. O estilo que ninguém segura: mano é mano! Boy é Boy! Boy é Mano? Mano é Mano? P. 12.

${ }^{56}$ Idem, p. 12.

57 Aglomeração natural de indivíduos de uma determinada espécie, como se observa nos rebanhos, colméias, formigueiros etc. 2 Tendência humana para formar um conjunto, partido ou sociedade. Dicionário Michaelis.

${ }^{58}$ Michel Maffesoli. O tempo das tribos, p. 12.
} 
O ideal comunitário do bairro ou da aldeia é contaminado por um imaginário coletivo. Para Maffesoli, podemos dizer que a ética (o laço coletivo) é, de certa forma, o cimento que fará com que diversos elementos de um conjunto dado formem o todo. É o que serve de caminho para os laços emotivos e formação dos sentimentos coletivos. "Aquilo que faz com que, bem ou mal, uns se ajustem ao outros num território determinado, e que uns e outros se ajustem ao meio natural." As relações sociais desse grupo atingem os extremos, mas são, de fato, ligadas por forte carga emocional. "Elaborada na felicidade e no infortúnio, originada de relações freqüentemente conflituais, ela é flexível, mas nem por isso deixa de apresentar uma longevidade espantosa. Ela é, na verdade, a expressão mais característica do querer-viver socia ${ }^{99,}$.

Esse viver social é baseado na cotidianidade, nos espaços urbanos, redesenhados pelos indivíduos. A reunião dos jovens em grupos ou tribos emana sem objeto e sem projeto específico algum, através da solidariedade, de um instinto não consciente de querer viver social (a ajuda-mútua). Nas redes de amizade, a "re-aliança" é vivida por ela mesma, sem qualquer projeção, seja qual for, isto é, o elo que existe entre os jovens não tem um fim planejado.

Existe a formação de um sentimento coletivo de força comum. Os jovens se associam a outros jovens que possuam interesses em comum; essa sensibilidade mística que fundamenta a perdurância, utiliza vetores bem triviais. Os lugares onde eles se encontram são lugares de convivialidade, de conversação. São os espaços públicos, como as lanchonetes, por exemplo. São espaços onde se pode dirigir ao outro, sem formalidades. $O$ ato de estar junto é uma forma de "sair de si", de constituir uma aura específica que serve de cimento para o tribalismo. Esses momentos representam a experiência, as crenças, os quadros coletivos de memória, as festividades, a promiscuidade sexual e outras efervescências ${ }^{60}$.

\footnotetext{
${ }^{59}$ Idem, p. 30.

${ }^{60}$ Ibdem, p. 38.
} 
Celebra-se também o consumo. A identidade do grupo é constituída pelas roupas usadas, os discos escutados, os shows freqüentados. As crenças de grupo são mercantilizadas e sua memória vendida sob a forma de coletâneas.

E, como não haveria de ser diferente, a indústria cultural quer a fugacidade dos gostos, uma flexibilização que possibilite o descarte ou que, pelo menos, dê precedentes para novos produtos culturais serem lançados. Isso vai ao encontro da própria dinâmica da juventude.

Os movimentos jovens, inclusive os de caráter político, são marcados por um vaivém, por certa fluidez e pela dispersão.

\begin{abstract}
Essa nebulosa "afetual" permite compreender a forma específica assumida pela socialidade em nossa em nossos dias: o vaivém massas-tribos. Com efeito, a diferença do que prevaleceu durante os anos setenta - com esses marcos que foram a contra-cultura californiana e as comunas estudantis européias - trata-se antes do ir-e-vir de um grupo a outro do que da agregação a um bando, a uma família, a uma comunidade. É isso que pode dar a impressão de atomização. É por isso que se pode falar, equivocadamente, de narcisismo. De fato, ao contrário da estabilidade induzida pelo tribalismo clássico, o neotribalismo é caracterizado pela fluidez, pelos ajuntamentos pontuais e pela dispersão. E é assim que podemos descrever o espetáculo da rua nas megalópoles modernas. $\mathrm{O}$ adepto do jogging, o punk, look retro, os "gente-bem", os animadores públicos, nos convidam a um incessante travelling. ${ }^{61}$
\end{abstract}

Para o autor, essas sedimentações criam o "estar junto" da socialidade. Nessa ambiência que nascem as condensações instantâneas, frágeis, mas marcadas por grande envolvimento emocional. O envolvimento entre os jovens de grupos específicos é marcado pela representação, que vai ser o meio pelo qual se obtém o pertencimento e se estreitam os laços da tribo. A teatralidade instaura e reafirma a comunidade. " $A$ estética (o sentir em comum) é um meio de experimentar, de sentir em comum e é, também, um meio de reconhecer-se. Em todo caso, a matriz da vestimenta, os cabelos multicoloridos e outras manifestações do punk, servem de cimento".

${ }^{61}$ Ibdem, p. 107. 
Essa teatralidade é englobada na produção cultural, que vê na formação dessas tribos a oportunidade de mercantilização de suas manifestações. Tudo pode ser vendido, desde o spray para o cabelo, aos brincos utilizados. Cria-se um aparato para criar o indivíduo punk e essa criação ocorre através do consumo.

$\mathrm{Na}$ socialidade vivida pelo grupo, vários signos os unirão e outros os diferenciação de alguns grupos. "O culto do corpo, os jogos de aparência, só valem porque se inscrevem numa cena ampla onde cada um é, ao mesmo tempo, ator e espectador. Trata-se de uma cena que é comum a todos. A acentuação está menos no que particulariza do que na globalidade dos efeitos" (Maffesoli, 200, p. 108).

As tribos também são marcadas por ritos, essas experiências são necessárias para a representação do grupo. Os ritos de entrada, por exemplo, são constantes em quase todos os subgrupos.

\begin{abstract}
Estes ritos de massa tribais (ritos de massa e ritos tribais) são perceptíveis nos diversos ajuntamentos que, pelo viés do processo midiático, assumem a importância que todos conhecemos. Vamos encontrá-los na fúria consumista das grandes lojas de departamentos, dos hipermercados, dos centros comerciais que, é certo, vendem produtos, mas, antes de tudo, destilam simbolismo, quer dizer, a impressão de pertencer a uma espécie em comum. Podemos, observá-lo, igualmente, nesse caminhar sem rumo definido que observamos, com atenção, este ombro-a-ombro indistinto, que se assemelha às peregrinações animais, é, de fato constituído por uma multidão de pequenas células que entram em interação. Ele é, igualmente, pontuado por uma série de reconhecimentos, de pessoas e de lugares, que fazem desse caldo de signos de cultura, um conjunto bem ordenado. ${ }^{62}$
\end{abstract}

Todos esses elementos, presentes na cultura dos jovens (baseados no tribalismo), somados à perspectiva da indústria cultural e do consumo, serão importantes para que possamos estudar a cultura da juventude nas décadas de 1970 e 1980.

62 Ibdem, p. 139-140. 


\section{CAPÍTULO III \\ CULTURA DA JUVENTUDE BRASILEIRA NAS DÉCADAS DE 1970 E 1980}

\subsection{JUVENTUDE BRASILEIRA, CONTRACULTURA E CONSUMO}

O movimento contracultural, como vimos no capítulo anterior, foi um dos momentos mais importantes da cultura jovem no mundo. No Brasil, suas raízes se deram através da Tropicália, tema que abordaremos a seguir. Acontece que o tropicalismo teve sua origem no ano de 1967 (seu auge continuou nos dois anos seguintes) e, assim, pode-se perguntar o porquê da inclusão desse movimento em um estudo da década de 1970. Concordamos com Maria Rita Kehl ${ }^{63}$, ao dizer que essa década não começou exatamente no dia 1ํ de janeiro de 1970, mas a partir do ano de 1968.

Um outro ponto importante é que o Brasil viveu nos anos 1970, a "ressaca" do movimento de contracultura da década anterior e por ela foi influenciado. A cultura brasileira viveu um marasmo ocasionado pela repressão militar que dilapidava as produções artísticas, enquanto a população consumia a produção do rock internacional, especialmente americano e, quando não, escutava as bandas que reproduziam seus ídolos estrangeiros.

Sobre a primeira explicação - a do início da década de 1970 - temos um fato que seria o divisor de águas das duas décadas: a publicação do Ato Institucional № 5 (Al-5), pelo presidente Arthur da Costa e Silva, em 13 de dezembro de 1968. Entre as suas principais ordens estavam a dissolução do Congresso, a proibição de reuniões políticas e o fortalecimento da censura (com relação às artes e assuntos de políticos).

\footnotetext{
${ }^{63}$ KEHL, M. R. As duas décadas dos anos 70. Maria Rita Kehl. P. 31-37. In: ANOS 70: Trajetórias. São Paulo: Iluminuras - Itaú Cultural, 2005.
} 
Nesse período, a música - e todas as outras expressões artísticas do movimento contracultural - ou a guerrilha armada de esquerda se tornaram as únicas formas de combate ao regime autocrático brasileiro.

\begin{abstract}
Na passagem da década de 1960 para a de 1970, os segmentos mais inquietos da juventude urbana brasileira se distribuíam em duas vertentes radicais: a esquerda e o movimento contracultural. A aproximá-los, havia o sentimento de que os caminhos "tradicionais" da transformação social estavam bloqueados, de que as velhas estratégias já não tinham o que oferecer. Daí, o resto, o antiintelectualismo e o fascínio pelo lumpemproletariado, que podemos flagrar tanto no ambiente contracultural quanto em meio às organizações de guerrilha urbana. Eram índices que apontavam, festiva ou desesperadamente, para a falência das fórmulas canonizadas. $^{64}$
\end{abstract}

O marasmo da década de 1970 foi conseqüência desses fatores políticos apontados e de uma eterna comparação da mídia entre os movimentos que surgiam e que, segundo eles, não conseguiam alcançar a criatividade e inovação demonstradas por Caetano Veloso, Gilberto Gil e os outros participantes da tropicália.

Desse modo, a produção tropicalista foi o ícone da contracultura nacional e a base musical, e comportamental, que guiou os jovens até meados da década de 1970. Após o seu enfraquecimento, a juventude nacional foi embalada pelo Rock contracultural de Raul Seixas e pela criatividade da banda Os Mutantes, que depois da saída de sua vocalista - Rita Lee - enveredou pelos caminhos do Rock "pesado", liderados por Arnaldo Baptista; além de embarcar na "onda" da discomusic e observar a formação de ídolos pop nacionais, como As Frenéticas, tomando novos rumos a partir do começo dos anos 1980.

3.1.1 Um pouco de Alegria, alegria no cenário brasileiro: contracultura e formação do Tropicalismo.

${ }^{64}$ RISÉRIO, A. Duas ou três coisas sobre a contracultura no Brasil. In: ANOS 70: Trajetórias. São Paulo: lluminuras - Itaú Cultural, 2005, p. 25. 
O movimento contracultural é, por natureza, uma atividade de ruptura. De acordo com Cláudio Novaes Pinto Coelho ${ }^{65}$, "no Brasil, a contracultura foi um movimento social que procurou romper com a modernização da sociedade brasileira posta em prática de forma autoritária pela ditadura militar, estabelecida no país com o golpe de 1964".

O Estado poderia ser visto com o sujeito principal da vida social, pois era a encarnação da racionalidade; cabia aos seus "braços", controlar e organizar todas as dimensões da sociedade, para que o país pudesse alcançar o progresso econômico.

Essa racionalidade do Estado era combatida pela contracultura, através da sua subjetividade. Como não "pegava nas armas", tentava combater as raízes ideológicas do Estado autoritário. Sua música e manifestações iriam contra tudo aquilo apregoado pelo Poder para ser seguido pela sociedade.

No período de 1969 a 1974, apenas a luta armada - além da contracultura - procurava combater a sociedade vigente. Mas, ao contrário da luta armada, que priorizava o combate ao aparato repressivo do Estado, a contracultura dirigia-se para o que, de acordo com a sua visão de mundo, seria o fundamento do autoritarismo: a racionalização da vida social. $O$ questionamento contracultural da racionalidade incidia nas mais diferentes dimensões da vida cotidiana. O caráter pluridimensional dessa prática social aparecia nas suas principais características: a ênfase na subjetividade em oposição ao caráter objetivo/racional do mundo exterior, a aproximação com a "loucura" e a marginalidade, a construção de comunidades alternativas. $^{66}$

Opinião corroborada por Antonio Risério, ao afirmar que "existia uma grande distância entre a metralhadora dos jovens de esquerda e o LSD da contracultura ${ }^{67}$. Não podemos é pensar que a contracultura foi fabricada pelo regime autoritário brasileiro (ou nasceu apenas para combatê-lo). Era um movimento internacional que "desembarcou" também no Brasil.

${ }^{65}$ COELHO, C. N. A contracultura - o outro lado da modernização autoritária. Cláudio Novaes Pinto Coelho. In: ANOS 70: Trajetórias. São Paulo: lluminuras - Itaú Cultural, 2005. P. 39.

${ }^{66}$ Idem. P. 39.

${ }^{67}$ Risério, p. 26. 
Em cada país onde esteve presente, a contracultura sofreu dificuldades políticas. Como explica esse autor, "exatamente ao contrário do que se chegou a proclamar, a contracultura se expandiu no Brasil não por causa, mas apesar da ditadura" (Risério, 2005, p. 26).

Podemos observar na contracultura nacional desse período, um retorno ao debate, renascimento do espaço público, representado por várias reinvenções estéticas $^{68}$.

No Brasil, o movimento contracultural se balizou por um espírito contestador, indo contra aos "desmandos" da Ditadura nacional "em sua marcha para uniformizar e asfixiar a juventude brasileira” (Risédio, 2005, p. 26). Facilitou o encontro entre os jovens de diferentes classes sociais e de diferentes lugares do Brasil, possibilitando a troca de vivências e linguagens, por vezes baseadas no consumo de drogas, mas que não diminui sua importância. Principalmente, porque o uso de tóxicos nesse período tinha uma conotação completamente diferente dos dias de hoje. Na década de 1960, seu uso era atrelado a formas místicas de pensamento e expansão da consciência.

Ao subir o "morro" em busca de drogas, acontece um intercâmbio de culturas entre os jovens. Em suas pesquisas, Darcy Ribeiro ${ }^{69}$ mostrou a comunicação existente entre a juventude de classe média e a de baixo poder aquisitivo. Dessa relação, que a gíria das favelas acabou se englobado ao vocabulário da sociedade em geral, como exemplo, temos "desbunde" e "fazer a cabeça".

Assim como nos Estados Unidos, muitos jovens brasileiros decidiram se integrar à vida livre, deixar suas casas, viver em contato com a natureza e deixar seus bens materiais.

Um dos desdobramentos da contracultura da década de 1960, ocorrido no Brasil dos anos 70 , foi certa opção pela vida simples, à margem dos valores da sociedade de consumo. Muitos jovens desejavam sair de casa,

\footnotetext{
${ }^{68}$ SEVCENKO, N. Configurando os anos 70: a imaginação no poder e arte nas ruas. In: ANOS 70: Trajetórias. São Paulo: Iluminuras - Itaú Cultural, 2005, p. 13

${ }^{69}$ A pesquisa foi citada por RISÉRIO (2005, p. 26)
} 
ser livres, sem as cobranças paternas. Ter vida própria, enfim: levar uma vida modesta, contentar-se com pouco. Bastava o colchão em um canto do piso do quarto, o som ao lado, revistas e livros empilhados, almofadões em substituição ao sofá e geladeira quase sempre vazia. ${ }^{70}$

Os jovens escolhiam uma vida independente, fora do convencionado pela sociedade. Para o jornalista Eduardo Lins e Silva, "havia naquela época uma guerrilha em curso, não apenas estritamente política. Combatia-se também no campo dos costumes; sobrevivia a idéia de que era preciso encontrar formas alternativas de vida $^{71}$ ". O conservadorismo dos pais não aceitava essas atitudes. Mas para os jovens, essa filosofia era transportada até para as relações afetivas, onde havia um desapego com relação a união entre pessoas nos moldes do status quo: a monogamia era substituída pela experiência do "amor livre".

A juventude recusava a cultura oficial. Por isso mesmo, havia a necessidade da criação de espaços alternativos, além daqueles oficializados, fora do mundo dos shoppings, utilizando vestimentas não-convencionais e adereços das feiras hippies. Tudo isso era uma forma de negar as convenções sociais impostas pela classe média urbana. Influenciados pela contracultura, muitos desses jovens saíram dos grandes centros rumo a repúblicas hippies, uma dessas sociedades era na praia da Arembepe, Bahia.

Aos que não migravam para as comunidades alternativas, existia ainda a opção de locais, nos centros urbanos, onde iriam interagir com outros jovens simpatizantes do movimento, em que poderiam se reconhecer através da moda (vestimentas e adereços) e das gírias. O Rio de Janeiro, por exemplo, possuía alguns desses espaços de convivência hippie.

O píer tornou-se a praia hippie de Ipanema, um grande underground a céu aberto, o epicentro do desbunde - e, como tal, freqüentado por gente de tudo o tipo, muitos sem nenhuma intimidade com a areia. Rose di Primo acabara de lançar ali a tanga, mas a moda no Pier eram as saias longas com o umbigo de fora e as batas indiana. Havia também quem circulasse vestido de calças Saint-tropez, macacões e até ponchos. Sob um sol de

\footnotetext{
${ }^{70}$ CARMO, P. S. Culturas da Rebeldia: a juventude em questão. São Paulo: Editora Senac, 2001, p. 118.

${ }^{71}$ Comentário citado por CARMO (2001, p. 118)
} 
quarenta graus, raros caiam na água. Não era uma praia, era uma atitude (...) As conversas eram sobre mapa astral, macrobiótica, orientalismo, comunidades alternativas, a "nova era", o disco do Cream, a peça Hair ou o último reparte de cannabis na praça. Ali se venderam os primeiros sanduíches naturebas, os livros de poesia da Geração Mimeógrafo e gibis, revistas e jornais alternativos. ${ }^{72}$

Além de toda a ideologia contracultural, os hippies pregavam também a liberdade feminina. Seguindo o exemplo americano, a juventude brasileira pregava a independência para as mulheres, oprimidas pela sociedade machista nacional. Nesse momento nasce a figura de Leila Diniz, um ídolo para as gerações seguintes.

Leila Diniz, estrela do cinema nacional e da tevê, desponta como uma das inovadoras na liberação dos costumes: inúmeros namoros, sexo livre e linguajar pouco convencional para a maioria das mocinhas da sua época. Ao expor, na praia, sua avançada gravidez num biquíni, mereceu protestos até mesmo de mulheres e de leitores de jornais, e um deles se posicionou contrário "à exibição vulgar de um estado de graça que é a maternidade". Leila foi uma das mulheres que abriu caminho para que as futuras gerações pudessem enfrentar com naturalidade, por exemplo, o trabalho fora de casa e fazer o que achassem melhor. Morta em 1972, aos 27 anos, em acidente aéreo na Índia, tornou-se um dos símbolos da emancipação feminina. ${ }^{73}$

Mas não só nas atitudes e comportamento o movimento hippie se fez no Brasil; na música também ganhou seus representantes. "O grupo musical Os Novos Baianos foi a mais perfeita tradução da filosofia hippie do momento" (Carmo, 2001, p. 19). Suas músicas encarnavam todo o sentimento da época. "De Arembepe, passando por São Paulo e se fixando em um sítio no Rio de Janeiro, viveram em comunidades, com alimentação natural, muitos filhos e muita música". O grande sucesso da banda foi a canção Preta, pretinha.

De fato, o movimento hippie é uma das facetas mais conhecidas do movimento contracultural, mas ela foi mais forte nos Estados Unidos. Em cada país do mundo, a contracultura se apresentou de um jeito diferente. Em Paris, por

\footnotetext{
72 Ruy Castro. Ela é Carioca: uma enciclopédia de Ipanema. São Paulo: Companhia das Letras, 1999, p. 28). Citado por CARMO, 2001, p.119.

${ }^{73}$ Idem. P. 119
} 
exemplo, a juventude se organizou contra o sistema capitalista e a sociedade de consumo.

\begin{abstract}
Abalando as estruturas da sociedade, o movimento dos franceses eclodiu inicialmente contra a situação arcaica do ensino superior para, em seguida, desembocar numa insatisfação com o desenvolvimento do capitalismo, a alienação, o consumo, a guerra, o poder. Os estudantes chegaram a paralisar o país e sugerir que a imaginação tomasse 0 poder. $^{74}$
\end{abstract}

No Brasil, a contracultura teve como movimento mais forte a Tropicália. Mas, em seu início, o tropicalismo não queria se tornar algo organizado para combater a repressão; ele nasceu de uma preocupação entusiasmada pela discussão da novidade.

No momento em que a música de Caetano Veloso, Alegria, alegria, e a canção Domingo no Parque de Gil participaram do III Festival da música Popular Brasileira, não existia nenhuma intenção de se formatar uma nova tendência e, além do mais, esses artistas nunca tinham pensado em se tornar porta-vozes de qualquer movimento.

Nesse período, existia uma grande efervescência na área da cultura e da política. Havia um intenso debate sobre a música brasileira e os ritmos estrangeiros, uma preocupação em reforçar nossos traços tradicionais e evitar uma "hibridização" da cultura nacional com o ritmo pop americano. Essa rivalidade foi uma das motivadoras dos Festivais de Música, que tinham como base, premiar as canções que exaltassem a criatividade e traços identitários nacionais.

Acontece que as músicas de Caetano e Gil destoavam das outras enquadradas no que se denominava MMPB (Moderna Música Popular Brasileira).

No contexto brasileiro, o movimento estudantil se consolidava cada vez mais, e foi o principal setor de contestação à ditadura no Brasil. Como era o

${ }^{74}$ Ibdem, p. 77 
público preponderante nos festivais, quaisquer canções ganhavam ares de debate público dos estudantes sobre os problemas que aconteciam no país. De acordo com Paulo Sérgio do Carmo, no ano de 1967, os festivais da TV Record tinham gigantesca participação da população, em especial, da juventude. "O novo surto de exaltação nacionalista fez da MPB símbolo de resistência ao golpe de 1964 e à invasão cultural estrangeira" (Carmo, 2001, p. 66).

O sucesso atingido por Gil e Caetano iniciava o tropicalismo. No entanto, a crítica foi forte aos artistas, principalmente pelas novidades acrescentadas às músicas, especialmente, a utilização da guitarra elétrica, pois, segundo os mais conservadores, violava a pureza da nossa música.

\begin{abstract}
Ao público consumidor desse tipo de música - formado preponderadamente por universitários - tornava-se difícil reconhecer uma postura política participante ou certo lirismo, que davam a tônica à maior parte das canções da época. A novidade - o moderno de letra e arranjo -, mesmo que muito simples, foi suficiente para confundir os critérios reconhecidos pelo público e sancionados por festivais e crítica. Segundo tais critérios, que associavam a "brasilidade" das músicas dos festivais à carga de sua participação político-social, as músicas de Caetano e Gil eram ambíguas, gerando entusiasmos e desconfianças. Acima de tudo, esta ambigüidade traduzia uma exigência diferente: pela primeira vez, apresentar uma canção tornava-se insuficiente para avaliá-la, exigindo-se explicações para compreender sua complexidade. Impunha-se, para crítica e público, a reformulação da sensibilidade, deslocando-se, assim, a própria posição da música popular que, de gênero inferior, passaria a revestir-se de dignidade, fato só mais tarde vivenciado. ${ }^{75}$
\end{abstract}

Alegria, alegria tinha uma sensibilidade moderna, "fruto da vivência urbana dos jovens imersos no mundo fragmentário de notícias, espetáculos, televisão e propaganda" (Favaretto, 1996, p. 18). Trazia todos os elementos da contracultura: de uma vida leve, não empenhada. Os problemas nacionais, debatidos em seu texto, estavam misturados a elementos do cotidiano da juventude da classe média urbana, retirando o seu caráter trágico. A leve batida de acompanhamento (feita pelos Beat Boys) somada à interpretação de Caetano dava um tom neutro à canção, diferente do tom apresentado pelas outras melodias, recheadas de declarações eufóricas contra a situação do país.

${ }^{75}$ FAVARETTO, C. Tropicália - alegoria, alegria. São Paulo: Ateliê Editorial, 1996, p. 17-18. 
Em meio às declarações políticas existiam várias referências ao consumo como ao falar de Brigite Bardot e Coca-Cola - causando um grande estranhamento em seus ouvintes.

A atividade dos tropicalistas pode ser vista através de duas características principais: a fruição estética e a crítica social. As inovações de ritmo trazidas pelo pop e pela mistura de sons nacionais são contrastadas por letras de elevada erudição abordando os problemas sociais brasileiros e fazendo crítica ao regime autocrático.

Com suas canções, Caetano e Gil se tornaram astros. Como nos diria Theodor Adorno, ocorre a industrialização da obra cultural, a mercantilização da arte. A imprensa se encarregou de fazer de suas declarações desabusadas, um produto vendável ${ }^{76}$. "De sua verve crítica, o prenúncio de uma posição artística, e mesmo política, sincronizada com comportamentos da juventude de classe média, vagamente relacionada ao movimento hippie" (Favaretto, 1996, p. 19).

Através de uma visão frankfurtiana, a indústria cultural trabalha por meio de sistemas harmônicos, somando a produção cultural e os setores de produção em si. No que diz respeito à cultura jovem, ao meu ver, a indústria cultural agiu (e age) de três formas distintas - naqueles movimentos que tiveram o apelo suficiente para se tornarem destacados: no caso dos movimentos surgidos espontaneamente, aconteceu a mercantilização de aspectos essenciais de sua representação, como vestimentas e produção musical, como foi o caso do movimento hippie; existem as produções lançadas pela indústria fonográfica e do entretenimento, com base em dados, pesquisas e tendências do comportamento jovem, como a disco-music e astros como Madona e Michael Jackson; e, por último, quando os representantes da cultura jovem se utilizam dos meios de comunicação e do consumo para expandir sua mensagem ou, simplesmente, para que eles sirvam de elo para a sua identificação, no primeiro caso, o exemplo do rock brasileiro politizado da década de 1980 e, no segundo, do movimento punk.

\footnotetext{
${ }^{76}$ O nome Tropicália foi dado ao movimento pelo Jornalista Nelson Motta em sua coluna Roda Viva, especializada no público jovem.
} 
Nesse sentido, os meios de comunicação são formas de reforço desse caráter mercantilista, pois sua abordagem em cima dos movimentos "mensura" o grau de "industrialização" da cultura jovem. Nos meios escritos, isso se torna mais evidente, pela possibilidade de análise mais profunda ou mesmo pela quantidade de vezes em que tal movimento é pauta na imprensa, vide os exemplos da Revisa Veja e do Jornal Folha de São Paulo (analisados no próximo capítulo).

A tropicália, desse modo, foi uma invenção da imprensa, em cima do movimento de renovação estética proporcionado pelos artistas baianos, mais tarde, reforçado pelo trabalho de marketing do empresário Guilherme Araújo. "O tropicalismo surgiu assim como moda; dando forma a certa sensibilidade moderna, debochada, crítica e aparentemente não empenhada" (Favaretto, 1996, p. 19).

Tínhamos, assim, uma moda atrelada ao comportamento hippie, com base em suas expressões psicodélicas e elementos do pop, reconhecíveis pela síntese de som e cor, associado a elementos da cultura tradicional brasileira, o que se convencionou chamar de cafonismo.

Apesar de não ter sido pensado por Gil e Caetano, esse aspecto publicitário do movimento não foi descartado por eles, pelo contrário, acabou sendo utilizado na sua produção, "estabelecendo assim uma forma específica de relacionamento com a indústria da canção". Gilberto Gil comenta sobre essa versão da criação da Tropicália:

$\mathrm{Na}$ verdade, eu não tinha nada na cabeça a respeito do tropicalismo. Então a imprensa inaugurou tudo aquilo com o nome de tropicalismo. E a gente teve que aceitar, porque tava lá, de certa forma era aquilo mesmo, era coisa que a gente não podia negar. Afinal, não era nada que viesse desmentir ou negar a nossa condição de artista, nossa posição, nosso pensamento, não era. Mas a gente é posta em certas engrenagens e tem que responder por elas. ${ }^{77}$

\footnotetext{
${ }^{77}$ Entrevista de Gilberto Gil citada por FAVARETTO, 1996, p. 19.
} 
A grande questão é saber se esse consumo poderia desvalorizar a criação cultural do movimento. Essa absorção os valores capitalistas poderia condizer com um movimento contestatório do sistema? Para Celso Favaretto, a mistura dos tropicalistas teve sua maior importância através da inserção histórica no processo de revisão cultural, que se desenvolvia desde o início dos anos 60. "Os temas básicos dessa revisão consistiam na redescoberta do Brasil, volta às origens nacionais, internacionalização da cultura, dependência econômica, consumo e conscientização" (Favaretto, 1996, p. 25).

Eles souberam utilizar os elementos midiáticos como forma de chegar mais perto do seu público. O rádio e a televisão já eram veículos importantes e consolidados. "Cada vez mais constatava-se que a música era também comportamento, atitude, política e moda". Para se atingir o público jovem, deveriam usar roupas e ter comportamentos mais condizentes com o cenário da moda no país. "Com talento e intuição, Caetano, Gil, Tom Zé, Rogério Duprat, Os Mutantes e outros conseguiram sintetizar as energias criativas que impulsionavam a modernização da cultura nos anos 60" (Carmo, 2001, p. 68).

O uso dos elementos da cultura pop e seu caráter consumista serviram como forma de divulgação da tropicália, mas também foram a base para sua produção artística, como forma de criticar a música nacional.

\footnotetext{
O tropicalismo também integrou elementos da musica pop, então moda mundial. A integração se deu devido à preocupação com o consumo e, acima de tudo, devido às possibilidades apresentadas pelo pop de, combinando-se com outros elementos, produzir efeitos artísticos de crítica à música brasileira. ${ }^{78}$
}

Além disso, o tropicalismo tinha uma estreita relação com o movimento antropofágico ${ }^{79}$ inaugurado por Oswald de Andrade. Em sua base, a tropicália justapunha elementos de variadas culturas, "em que contradições históricas, ideológicas e artísticas são levantadas para sofrer uma operação

\footnotetext{
${ }^{78}$ Idem, p. 40.

${ }^{79}$ Lançado na Semana de Arte Moderna de 1922, o manifesto tinha como base a crítica à erudição e busca de uma identidade nacional.
} 
desmistificadora". Ao mesmo tempo, conseguia se tornar representante da realidade nacional, "apesar de operar ao nível de uma descentralização cultural' (Favaretto, 1996, p. 23).

Inserido no contexto da modernidade, o movimento tropicalista "incorporava o caráter explosivo do momento às experiências culturais que vinham se processando; retrabalhava, além disso, as informações então vividas como necessidade, que passavam pelo filtro da importação" (Favaretto, 1996, p. 27). Desse modo, apesar de incorporar elementos da cultura pop, a tropicália "selecionava" tais elementos e os incorporava ao contexto nacional. A guitarra, por exemplo, era introduzida em sons típicos do cancioneiro brasileiro (como a música nordestina).

Reinventando ou criticando as nossas tradições, seus artistas utilizavam o cosmopolitismo na sua produção artística.

Ao fazer isso, cresceu o debate sobre a "pureza" de sua música. Se nos baseássemos nos teóricos da Escola Crítica, a obra dos tropicalistas estava perdendo a sua "aura". Seria então o tropicalismo uma forma de arte - ativa em seus elementos contestatórios e sui generis por ser uma forma de concepção baseada na cultura popular brasileira -, ou simplesmente forma de produção artística alienada, feita com base na demanda musical de um público jovem ávido por novidades?

O que chegava, seja por exigência de transformar as linguagens das diversas áreas artística, seja pela indústria cultural, foi acolhido e misturado à tradição musical brasileira. (...) Entretanto, em função da mistura que realizou, com elementos da indústria cultural e os matérias da tradição brasileira, deslocou tal discussão dos limites em que fora situada, nos termos da oposição entre arte participante e arte alienada. $O$ tropicalismo elaborou uma nova linguagem de canção, exigindo que se reformulassem os critérios de sua apreciação, até então determinada pelo enfoque da crítica literária. Pode-se dizer que o tropicalismo realizou no Brasil a autonomia da canção, estabelecendo-a como um objeto enfim reconhecível como verdadeiramente artístico. ${ }^{80}$

${ }^{80}$ FAVARETTO, 1996, p. 27-28 
Nesse mesmo sentido, afirma Paulo de Tarso Medeiros ${ }^{81}$ que a música tropicalista guarda uma imensa riqueza de erudição poética e inovação estética. Mas essa música também era vendida como mais uma mercadoria pela indústria cultural, "mas que, no entanto, parecem conter um caráter de negação do próprio esquema e dos valores que ele agrega. Paradoxalmente, utilizam a máquina empresarial como meio de combatê-la" (Medeiros, 2004, p. 50).

Utilizando todos esses elementos, os tropicalistas queriam fazer uma crítica de todos os gêneros e até mesmo dos veículos de divulgação, desmistificando a arte imposta pela burguesia. Apesar do uso de instrumentos eletrônicos, ruídos e vozes, eles seguiam a linha evolutiva, fazendo, sempre, uma crítica à canção. As últimas músicas gravadas demonstram essas características, a saber: questão de ordem, divino maravilhoso, cultura e civilização, entre outras.

Paulo Sérgio do Carmo acredita que, de fato, a música tropicalista ressaltava características do universo pop, "como a sedução do consumo, 0 efêmero na publicidade, o cenário urbano". Ao se utilizar desses elementos, "Caetano Veloso buscava superar as divisões simples da época, como cultura nacional versus internacional, arte engajada versus arte alienada”. (Carmo, 2001, p. 69).

$\mathrm{Na}$ Letra de Alegria, alegria, podemos perceber como a sociedade de consumo se torna a inspiração para se pensar o mundo moderno e se contrasta com a realidade vivida no país.

A canção marca o despontar da sociedade de consumo - o fascínio da
publicidade. Pode-se ver mais influência da pop art, movimento cultural
americano, cujos temas mais importantes relacionavam-se com a vida
urbana e seus produtos de consumo. A garrafa de Coca-Cola era
transformada em mito da vida moderna, bem como do consumo supérfluo
- como Andy Warhol (1929-1987), o papa do movimento, deixou gravado
em uma de suas obras. Música pop, no entendimento de Gilberto Gil, "é
uma música que se consegue comunicar de maneira tão simples como um
cartaz de rua, um outdoor, um sinal de trânsito, uma história em
quadrinhos".

${ }^{81}$ MEDEIROS, P. T. Mutações do sensível: rock, rebeldia pós-68. João pessoa: Manufatura, 2004
${ }^{82}$ CARMO, 2001, p. 70. 
Se a tropicália foi uma "invenção midiática" e, assim, tornou-se mercantilizada pela ação da indústria cultural, ela também conseguiu utilizar-se dos elementos dessa indústria para sua construção artística e, através de seus veículos, disseminar sua mensagem. A crítica de Alegria, alegria era a da nãopreocupação com o imperialismo cultural, na qual, deveríamos valorizar nossa cultura, sem a necessidade de colocá-la numa "redoma de vidro" contra a cultura estrangeira.

Diante do panorama controlador das esquerdas, Alegria, alegria era também um protesto na medida em que se rebelava contra a dominação da tendência nacionalista, que se pretendia hegemonia no campo da MPB. Além do elemento invasor como o rock, a Coca-Cola era considerada símbolo do imperialismo ianque. E o sujeito que caminha em Alegria, alegria não parece preocupar-se com isso. Alegria, alegria e Domingo no parque (de Gilberto Gil) se propuseram e assimilar o que há de novo nesses movimentos de massa e de juventude e incorporar as conquistas da moderna música popular aos seus próprios campos de pesquisa, sem, por isso, abrir mão dos princípios formais de suas composições, que se assentam, com nitidez, em raízes musicais nordestinas. ${ }^{83}$

Apesar do papel desempenhado na crítica contra a sociedade e o regime militar, os tropicalistas não tiveram por muito tempo, o apoio do público que freqüentava os Festivais de Música.

Em 1968, a proposta de "derrubar estantes, prateleiras e livros", de É proibido proibir, música de Caetano Veloso que retoma as palavras recebidas de ordem do movimento estudantil francês (Maio de 1968), seria recebida pela platéia com uma sonora vaia. Ante o conservadorismo estético da maioria da platéia, Caetano interrompe a apresentação com um desabafo: "mas é isso que é a juventude que diz que quer tomar o poder? E conclui: "se vocês em política forem como em estética, estamos feitos!"

A peça Roda Viva também sofria violentos protestos, em específico, uma ala extremista do CCC (Comando de Caça aos Comunistas) ${ }^{84}$, que depredou o

${ }^{83}$ CARMO, 2001, p. 70.

${ }^{84}$ Esse grupo paramilitar (extra-oficialmente apoiado pelo Estado) ficou famoso por empreender, no ano de 1968, a destruição do prédio de Filosofia da USP na Rua Maria Antônia, próximo à faculdade Mackenzie. Um estudante foi morto durante os confrontos. 
teatro e espancou atores e técnicos. No mesmo período ocorreram as vaias à música de Caetano, "que estaria diluindo a força da política de sua contestação com as roupas de plástico usadas pelos Mutantes". (Carmo, 2001, p. 67).

Segundo Heloísa Buarque de Holanda (citada por Carmo, 2001), o público politizado acusava os tropicalistas de omissão com relação ao regime ditatorial e seu crescimento no Brasil. Os objetivos estéticos do movimento deveriam ser deixados de lado, segundo os estudantes, para que o tropicalismo assumisse sua vertente revolucionária e seu papel de protesto ao Estado.

Já no final da década de 1960, o Governo, através dos seus órgãos censores, repreendia todas as manifestações, especialmente musicais, que tivessem mensagens - objetivas ou não - contra o Regime Militar. A atitude empreendida pela juventude se tornou "potencialmente perigosa" aos olhos do Estado. Quando entrou no ar o programa Divino, maravilhoso, apresentado por Caetano, Gil e outros tropicalistas, vários abaixo-assinados foram feitos, pedindo o fim de sua apresentação na TV Tupi.

A crítica social dos tropicalistas não era explícita, mesmo assim, eles não eram bem vistos pelos militares, tanto que, após a decretação do Al-5 no final de 1968, Caetano e Gil foram presos e, no ano seguinte, exilados para Londres. Isso ocasionou o fim do movimento.

As canções de protesto, que se desviavam de inovações estéticas, queriam se tornar instrumento contra a opressão do Estado Brasileiro. Esse tipo de música teve, por parte do Governo, uma retaliação bem mais forte. O regime militar pouco queria saber dos debates em torno das canções nacionalistas e consumo de música estrangeira. $O$ tropicalismo não era diferenciado de outras manifestações de oposição, todas eram consideradas "subversivas".

Caetano Veloso não compreendeu, no momento, o porquê de sua prisão, achava que sua música não tinha o perfil revolucionário como as canções de 
Geraldo Vandré ${ }^{85}$. De nada adiantou, o cantor teve passar quase dois meses presos.

\begin{abstract}
Estávamos tão habituados a hostilizações por parte da esquerda, éramos tantas vezes acusados de alienados e americanizados, que, quando me vi diante daqueles policiais, imaginei que me estavam levando para uma conversa algum oficial de São Paulo, o que nos trataria como rapazes interessados apenas em divertir o público.
\end{abstract}

O general Antônio Bandeira disse ao jornal Folha de São Paulo, em 2 de novembro de 1997, que Caetano e Gil, de fato, não incomodavam o regime, pois sua preocupação estava com guerrilheiros como Carlos Lamarca, que fugiu do Quartel de Quintaúna, em Osasco, no começo de 1969.

De fato, o que ocorreu foi a dissolução do movimento tropicalista, que foi tão rápido quanto importante. Suas inovações estéticas continuaram a ressoar pela década de seguinte e influenciam, até hoje, movimentos musicais no cenário brasileiro.

A mídia teve seu papel preponderante para a formação do movimento que, rapidamente, foi "mercantilizado", mas calou-se nos momentos em que a repressão militar se fez presente também nos meios de comunicação. A palavra de ordem era não falar sobre o tropicalismo.

Durante o começo da década de 1970, muito pouco (para não dizer quase nada) era publicado sobre a Tropicália. Os guetos que ainda se formaram, como os Novos Baianos ou as Escolas de Música de Tom Zé, não mereceram destaque nas páginas da imprensa nacional.

\footnotetext{
${ }^{85} \mathrm{Na}$ área musical, Geraldo Vandré era o alvo principal dos militares. Em setembro de 1968, no Festival Internacional da Canção, no Rio de Janeiro, Vandré concorreu com pra não dizer que não falei das flores ou Caminhando. Acabou acontecendo o que os militares mais temiam: canção tornou-se bandeira. Se, da perspectiva musical, não havia novidades em Vandré, a letra de sua canção atingiu o ponto sensível dos militares: a honra e o espírito da corporação. Os versos responsáveis pela façanha diziam: "há soldados armados, amados ou não/ quase todos perdidos de armas nas mãos./ Nos quartéis Ihes ensinam uma antiga lição,/ de morrer pela pátria e vivem sem razão" (Carmo, 2001, p. 72).

${ }^{86}$ CARMO, 2001, p. 71.
} 
Mesmo se suas inovações fossem dignas de nota ou se suas músicas contivessem críticas importantes ao regime - mesmo que de modo subjetivo -, em um país dominado por uma ditadura no qual o governante tinha poderes especiais e quase ilimitados para governar, não seria sensato fazer apologia a movimentos esquerdistas e "subversivos".

A indústria cultural atua de forma diferenciada quando inserida em regimes autoritários. Ela possui certos limites impostos pela realidade política do país.

A música, que poderia se tornar algo facilmente vendável, tinha que ser minuciosamente estudada para verificar se, no seu escopo, não existia um teor contrário ao Estado.

Um fato importante é que, nesse período, do começo da década de 1970 o país atravessava uma fase de desenvolvimento, ocasionado pela entrada do capital estrangeiro no Brasil. Vivíamos a prosperidade no consumo e é, nesse momento, que se estrutura a nossa indústria fonográfica.

Na década de 1970, para além do contexto mais específico relacionado às mídias e às tecnologias, outros exemplos podem ser arrolados com 0 objetivo de explicitar os mecanismos de crescimento do mercado de bens simbólicos: as transformações que ocorrem no campo editorial e a ampliação e consolidação do mercado fonográfico e de outros espaços de produção cultural, que mudam qualitativamente o cenário brasileiro, nos anos $70 .^{87}$

O público jovem, maior consumidor de discos, se encontrava sem ídolos, por conta do período político e a compra de discos estrangeiros era o que predominava no Brasil.

Durante toda a década, a produção artística, em geral, se viu prejudicada por conta do Regime Militar, por outro lado, o crescimento do consumo necessitava de uma maior produção cultural, de preferência, nacional.

\footnotetext{
${ }^{87}$ BORELLI, S. S. Cultura brasileira: exclusões e simbioses. In: ANOS 70: Trajetórias. São Paulo: lluminuras - Itaú Cultural, 2005, p. 53.
} 
3.1.2 Anos 70: pra frente, Brasil!

A Década de 1970 presenciou o auge e a derrocada do Regime Militar brasileiro. A partir do começo dos anos 1980, começou, no país, o processo de redemocratização.

A Copa do Mundo e o tricampeonato do futebol, no ano de 1970, deram ao governo um grande prestígio. A campanha do "Milagre brasileiro" deu a imagem necessária à população de que o país estava progredindo e que continuaria assim nos anos seguintes sob a batuta dos Militares. O povo estava do lado do presidente Médici.

Os anos 70 , que iniciaram no final de 1968 , foram terríveis. Todo mundo parecia apoiar a ditadura. Os brasileiros começavam a década torcendo pelo Brasil na Copa, "80 milhões em ação", unidos em torno da excelente seleção, que levou o tricampeonato. A vitória deu grande prestígio a Emilio Garrastazu Médici, o militar de plantão do governo. O plano econômico, apelidado de "milagre brasileiro", além de enriquecer ainda mais a burguesia, propiciou a expansão da classe média e elevou os padrões de consumo de muitas famílias: eletrodomésticos, carros, financiamentos da casa própria pelo Banco Nacional da Habitação, $\mathrm{BNH}^{88}$

Um dos fatos mais importantes é o início da Era da Televisão e consolidação da Rede Globo. Nesse momento, surge a TV a cores e ocorre a invenção do videoteipe, melhorando a formatação da grade de programação das emissoras.

Com a ajuda dos militares, a Globo é levada para todos os cantos do país, patrocinada pela expansão da rede de transmissão da Embratel. $O$ ufanismo tomou conta do Brasil, a integração do país era uma questão de "segurança nacional". É desse período a construção da rodovia transamazônica, cujo lema era "integrar para não entregar".

${ }^{88}$ KEHL, 2005, p. 32. Modificado. 
O país sofreu alguns problemas nesse período. No ano de 1973, aconteceu a crise do petróleo, que casou uma recessão em todo o mundo, no Brasil, "os postos de gasolina fecham aos domingos e feriados e discute-se a possibilidade de emissão de cupons de racionamento. Surge, então, o carro a álcool' (Carmo, 2001, p. 107).

$\mathrm{Na}$ área da educação, as faculdades particulares crescem no país e teríamos, no final dos anos 1970, quase um milhão de universitários. Em contrapartida, o ensino foi diminuído em seu aspecto crítico. A filosofia é retirada da carga horário do segundo grau e a disciplina História é reduzida para cronologia de fatos marcantes. Isso foi feito para evitar mensagens "subversivas" por parte dos professores.

É nesse contexto político e social que a cultura brasileira, especificamente a cultura jovem, teve que sobreviver. Apesar dos pesares, as manifestações tentaram ressaltar os elementos de rebeldia e contestação inerentes à juventude, enquanto a indústria cultural tentava mercantilizá-los para aumentar sua lucratividade.

$\mathrm{E}$, com base no crescimento da indústria fonográfica, podemos perceber que a juventude aumentou bastante seu consumo desse tipo de produto cultural. De acordo com Celina Aparecida Lucas ${ }^{89}$, entre 1966 e 1976 houve um crescimento de $444 \%$ no setor. Nesse momento foram importantes selos como a Philips, que comercializava os discos dos Tropicalistas.

3.1.3 Na época da juventude Mutante, ser Maluco era ser Beleza.

Nos Estados Unidos, vivia-se, nos anos 1960, uma época de mudanças, em que a juventude acreditava em novas possibilidades e quebra de valores da sociedade americana. A música esteve, desde o começo do movimento

\footnotetext{
${ }^{89}$ LUCAS, C. A. A Odisséia do disco na produção de segmento. Dissertação (Mestrado). Escola de Comunicações e Artes da Universidade de São Paulo, 2004.
} 
contracultural, lado a lado com esse pensamento. A canção $A$ casa do sol nascente do conjunto The Animals, e que ficou famosa na interpretação de Bob Dylan na década de 1960, por exemplo, é uma metáfora aos sonhos rebeldes de boa parte da juventude do período.

Sua letra falava do "novo jeans", uma referência não só a vestimenta usada pelos jovens, mas a um código de identificação, que reforçava o sentimento de distanciar-se dos padrões de roupas utilizados pelos seus pais.

Desse modo, Bob Dylan acabou por se tornar, um profeta dos "novos tempos" pela juventude americana. De acordo com Luiz Alberto Boscato ${ }^{90}$, no Brasil, "foi de maneira semelhante que toda uma geração de jovens dos anos 1970 viu em Raul Seixas um anunciador dos novos tempos, um guru, um caminho a seguir".

O baiano fez parte de uma geração que sentiu um estranhamento com relação a vida levada por seus pais, uma vida que era o espelho de uma sociedade conservadora.

Raul Seixas nasceu em Salvador, capital da Bahia, no dia 28 de junho de 1945. Naquele momento, a juventude era tomada por uma sensação de estranhamento com relação ao mundo de seus pais, que era expressa em filmes como Rock Around The Clock, produzido em 1955 e lançado no Brasil no ano seguinte com o título de Ao Balanço das horas. ${ }^{91}$

A canção-tema - Rock around the clock - foi essencial para popularização do rock no Brasil através de Bill Haley e seus Cometas. A banda criada por Raul Raulzito e os Panteras - foi inspirada nome da banda americana. O estilo das músicas era baseado nos Beatles, "com exceção da arrojada Você ainda pode sonhar, versão de Raul Seixas para a psicodélica Lucy in the Sky with Diamonds - também dos Beatles, só que essa já da fase que se desenvolve a partir de 1967' (Boscato, 2006, p. 93).

${ }^{90}$ BOSCATO, L. A. Vivendo a sociedade alternativa: Raul Seixas no panorama da contracultura jovem. Tese (Dourado). Faculdade de Filosofia, Letras e Ciências Humanas da Universidade de São Paulo, 2006, p. 92.

${ }^{91}$ Idem, p. 92. 
Ao contrário do movimento tropicalista (que apesar de adicionar elementos do pop, buscava mais uma inovação estética com a mistura de ritmos nacionais), Raul Seixas estava mais próximo das tendências internacionais da contracultura, em especial, do movimento hippie e do crescimento do rock'n'roll.

Do golpe militar até o ano de 1968, a cultura jovem - e o comportamento juvenil - estavam atrelados aos protestos contra o Regime Militar. Somente a partir de 1969 que um pensamento questionador da racionalidade começou a se articular no nosso país.

A imprensa brasileira começa a falar sobre um movimento hippie no Brasil somente no ano de 1969. A revista Veja de 12 de dezembro, por exemplo, publicou matéria a respeito de uma concentração hippie na Bahia, apontando ainda que esses movimentos já eram alvo de repressão policial:

\begin{abstract}
Eles brotaram de todos os lados, em grupos solitários, caminhando no acostamento das estradas ou pedindo carona aos viajantes mais simpáticos (...) Sua meta final: a cidade de Salvador. O motivo: uma concentração hippie na capital baiana. Mas quase nada deu certo. Em primeiro lugar, o delegado de Jogos e Costumes ameaçou prender todos eles por vagabundagem. Alguns hippies acreditavam que a sua grande festa seria em novembro. No entanto, os mais bem-informados juram que a concentração vai ser antes de janeiro. Outros dizem que a reunião de mais de 200 deles era apenas coincidência. E a mobilização enfraqueceu. Sem falar nos que nem chegaram à Bahia. ${ }^{92}$
\end{abstract}

Seguindo a tendência de mercantilização da cultura da juventude, como aponta Cláudio Novaes Coelho, no começo da década de 1970, começam a surgir publicações do universo underground relacionadas à contracultura, como Flor do Mal, Presença, Rolling Stone (edição brasileira), e também as feiras de arte hippies ou eventos como o Festival de Arembepe, realizado na Bahia em 1971. (Coelho, 2005, p. 41).

Existia nesse momento o pensamento de contestação da racionalidade que era a racionalização autoritária - como forma de questionar a própria

\footnotetext{
${ }^{92}$ REVISTA VEJA E LEIA de 12 de dezembro de 1969, p. 41.
} 
sociedade. A loucura hippie foi, então, uma nova forma de pensar e contestar o mundo, capaz de romper a lógica racionalizante do status quo.

\begin{abstract}
Ao assumir o rompimento com a racionalidade como uma forma de dissidência social, a contracultura expunha-se à ação repressiva da modernização autoritária. A repressão às práticas sociais contraculturais não se deu apenas pela prisão dos hippies, mas também pelo internamento dos loucos - um dos modos pelos quais os contraculturais se denominavam - nos hospitais psiquiátricos: a loucura contracultural era, simultaneamente, uma condição assumida pelos próprios hippies e um estigma a eles atribuído pelos "caretas". 93
\end{abstract}

Esse momento da cultura jovem, de uma mudança no pensamento e na racionalidade humanas - inspirou as idéia de Raul e, com base nessa reflexão e em outras, surgidas na década de 1970, é que ele pensou a sua Sociedade Alternativa.

Ela estava atrelada à idéia de John Lennon de criar uma nação universal sem pátria e nem patrão, a Nova Utopia, antevista nos versos da canção Imagine e esboçada através de textos do cantor. (Boscato, 2006, p. 131). Uma outra influência bastante forte em sua obra é a do ocultista britânico Aleister Crowley ${ }^{94}$. Seus rituais eram concebidos com a utilização de drogas. Muitas músicas de Raul Seixas remetem aos escritos desse "mago". Em algumas de suas canções, sua menção é expressa, como em Sociedade Alternativa. Com a famosa frase "faze o que tu queres, pois é tudo da lei", o cantor demonstrava seu desprezo ao Autoritarismo da ditadura militar, indignado com o cerceamento da liberdade da juventude.

Em meados dos anos 1970, Raul, com auxílio do escritor Paulo Coelho (amigo e parceiro em várias músicas) criou sua comunidade no interior de São Paulo. No local, colocava em prática suas reflexões sobre o papel da juventude na sociedade. Mas, como tudo o que contrariava o Regime Militar, o sítio foi considerado "subversivo" e o cantor preso.

\footnotetext{
${ }^{93}$ COELHO, 2005, p. 42.

${ }^{94}$ Seu trabalho influenciou grandes nomes do rock' $n$ 'roll como as bandas Iron Maiden, Beatles e Led Zeppelin.
} 
O ano de 1974 marcou uma escalada de ascensão no projeto de construção da Sociedade Alternativa, que contou com o artigo publicado por Paulo Coelho na Revista Planeta e o anúncio da instalação da Cidade das Estrelas no terreno em Paraíba do Sul. Mas foi justamente quando a repressão se tornou mais forte: a Polícia Federal recolheu todos os gibismanifesto $A$ fundação Krig-Há, e os queimou como se fazia na Alemanha nazista com os livros proibidos, alegando ser material subversivo, até o ponto de fechar a sede criada por Raul e prendê-lo. ${ }^{95}$

No que tange ao seu aspecto mercadológico, o rock no Brasil tinha a classe média como seu maior público consumidor. Então existia no movimento contracultural uma ambigüidade adesão/revolução, "muitas vezes, vinculados a uma reacomodação de forças dentro da própria sociedade, ainda que haja sinceridade por parte de seus principais ativistas no sentido de reivindicarem a construção de uma Sociedade Alternativa" (Boscato, 2006, p. 132), pois, por conta do poder de readaptação do capitalismo, muitos movimentos alternativos são transformados em produtos de consumo.

Esse autor acredita que o projeto de Raul seja diferenciado dos movimentos culturais da década de 1960. O cantor fazia uma crítica a eles, "contestando a sua eficácia no combate ao sistema e constatando a facilidade com que o hippismo permitiu que as suas posturas rebeldes e as suas bandeiras fossem facilmente banalizadas, e adaptadas pelo Capitalismo" (Boscato, 2006, p. 132). Aliado ao conteúdo mítico da Sociedade Alternativa existia uma premissa de transformação social e política.

Quando Raul afirmou na música Eu sou Egoísta, que "a guerra é um produto da paz", estava fazendo uma crítica à política de "paz e amor" e afirmando que ela contribuía para que os "senhores da guerra", como Bob Dylan chamava os donos do poder, continuassem exercendo seu domínio livremente. Embora os hippies ou os neo-hippies admirem Raul Seixas, ele considerava o hippismo um movimento derrotado, que fora facilmente cooptado pelo sistema. ${ }^{96}$

\footnotetext{
${ }^{95}$ BOSCATO, 2005, P. 147.

${ }^{96}$ BOSCATO, 2006, p. 132.
} 
Apesar das críticas que fazia ao capitalismo e ao sistema vigente, Raul mantinha estreitos laços com os meios de comunicação. Suas aparições na TV Globo na década de 1970 foram freqüentes. Era bem diferente dos outros artistas do underground que preferiam manter distância dos medias. Boscato acredita que essas aparições serviam para disseminar suas mensagens anarquistas e conseguir alcançar o grande público. A música Carimbador Maluco tinha esse papel, de acordo com o cantor.

Raul Seixas acreditava que o único meio de combater o sistema era estar inserido nesse próprio sistema.

A grande questão é que a "máquina" capitalista consegue "maquiar" os aspectos contrários ao sistema, reforçando apenas aqueles que podem ser vendidos.

O cantor utilizou os meios de comunicação para disseminar suas mensagens, mas por ele também foi usado, como produto mercadológico. A partir desse momento, a Sociedade Alternativa poderia ser vendida, esvaziada de seu conteúdo formador, como mero símbolo da moda. Alcançaríamos no Brasil, a exemplo do ocorrido nos Estados Unidos, uma forma de mercantilização do movimento e do pensamento hippie.

Desprovido de seu elemento contestador, diriam os frankufurtianos ortodoxos, a Sociedade Alternativa transformara-se em simples produto de massa.

O movimento hippie acabou tornando-se elemento de identidade juvenil. A publicidade, por exemplo, soube bem se utilizar desse idenfiticação. A utilização da música da época pelo aparato publicitário, além de servir para associar o produto à música que ilustra sua divulgação, também serve para divulgar essa ilustração sonora. Ela pode ser uma música específica já conhecida, uma composição especial para divulgação ou apenas um gênero musical ${ }^{97}$. Foi o caso de propagandas da Coca-Cola, nas quais músicas eram cantadas por jovens com vestimentas hippies, exaltando a liberdade relacionada ao ato de tomar a bebida.

${ }^{97}$ CORRÊIA, 1989, p. 29. Modificado. 
A "loucura" de Raul foi aceita pela sociedade, que o enxergava como um "maluco beleza" ou alguém com idéias "excêntricas", mas que não era considerado perigoso e nem subversivo para a juventude. E assim, vários outros jovens foram identificados do mesmo modo, a partir do momento em que o hippismo começou a se resumir a moda e ao fato de se comprar discos dos seus músicos prediletos do movimento.

Enquanto Raul Seixas começava sua carreira na década de 1960, um outro grupo de sucesso nascia: Os Mutantes. A sua importância para a cultura jovem nacional está relacionada tanto com a sua participação no movimento tropicalista, quanto para o começo do rock brasileiro.

No programa O pequeno mundo de Ronnie Von, no ano de 1966, o trio composto por Rita Lee e Arnaldo e Sérgio Batista fez a sua estréia. Causou bastante impacto ao mostrar a versão para duas guitarras (Rita tocou a segunda) e baixo elétrico da Marcha Turca de Mozart. Seu repertório inovador conquistou o público logo no começo de suas aparições.

Nas semanas seguintes, além de sucessos dos Rolling Stones e Peter, Paul e Mary, apresentaram também fugas de Bach, com arranjos e três vozes. Os mutantes chamaram atenção desde a primeira semana e logo começaram a receber convites para se apresentarem em outros programas da emissora, como o de Hebe Camargo. ${ }^{98}$

Existiam grandes diferenças entre a banda e os outros tropicalistas. Apesar de buscarem inovações estéticas, eles traziam informações novas, a partir de suas vestimentas, do comportamento e de suas atitudes ${ }^{99}$. Pareciam mais com os jovens Beatles-maníacos. Eles viviam o universo do rock' $n$ 'roll e todas as suas tendências. Por isso mesmo, tinham mais a simpatia dos jovens de todos as classes, indiferente de posição política.

\footnotetext{
${ }^{98}$ CALADO, C. A divina comédia dos mutantes. Rio de Janeiro: Ed. 34, 1995, p. 88-89.

99 "Os garotos traziam um modo debochado de fazer humor, muito diferente da atitude mais compenetrada dos músicos da bossa nova e da chamada MPB. Os três também mandavam às favas o conceito tradicional de elegância". (CALADO, 1995, p. 114)
} 
De fato, Os Mutantes tinham um caráter bem mais comercial que os músicos do tropicalismo. Conquistavam mais essa empatia pelo fato de tocar rock'n'roll, quem nem os ídolos jovens do momento - Os Beatles -, e também por deixarem de lado o discurso mais político e investirem em uma estética mais irreverente.

Por isso mesmo recebiam mais espaço da mídia, inclusive impressa. Os grandes shows dos Mutantes eram anunciados sempre que ocorriam.

O sucesso rendeu uma turnê internacional e, na volta ao país, receberam um convite para participar de um filme. Além disso, os Mutantes enveredaram pelo meio publicitário.

Criada pelo publicitário João Carlos Magaldi (o mentor do programa Jovem Guarda), a campanha apostava no público jovem para divulgar a marca da Shell - e, por conseqüência, vender seus produtos derivados de petróleo. $\mathrm{Na}$ televisão, a campanha começou com um pequeno filme de propaganda, estrela por Rita, Arnaldo e Sérgio. Toques de A Hard Day's Night e Help misturavam-se com humor de pastelão e o ritmo acelerado de comédias do cinema mudo. O resultado agradou e logo vieram outros filmes, formando uma série. ${ }^{100}$

Foram responsáveis, no campo da moda, pela disseminação da tendência psicodélica. Sabemos que tudo relacionado a um artista acaba sendo comercializado. Desse modo, a produção fonográfica tem estreita relação com outras formas da indústria cultural, se intrincando através de uma rede de produtos consumíveis pela juventude. O Rock dos Mutantes foi veículo de difusão de toda uma mudança da moda no nosso país.

Constata-se, então, que não apenas o disco, mas tudo o que se relaciona ao artista a partir da música que interpreta é consumido enquanto fatia de um processo de produção que interessa muito mais às estruturas de venda e lucro do que às de criação musical. Nesse sentido, a questão da qualidade daquilo que se tem produzido e comercializado pela indústria da música pode estar, portanto, mas relacionada a essa prática de utilização indiscriminada da música enquanto veículo de difusão e consumo de outros produtos. Assim sendo, o gênero musical que caracteriza o rock

${ }^{100}$ Idem, p. 171. 
enquanto veículo de difusão dos movimentos que lhe dão origem, concomitantemente ao fato de ele ser também veiculo de divulgação de produtos que a ele se associam e se destinam ao consumo, acaba se transformando em objeto na mídia na disseminação dos próprios movimentos de origem como uma mercadoria à venda. ${ }^{101}$

A partir de 1973, algum tempo depois da saída de Rita Lee, Os Mutantes abraçaram o rock'n'roll pesado. Como disse certa vez Arnaldo Batista: "não queremos mais só encher a barriga do público de som. Nossa jogada agora é fazer as pessoas pensarem um pouco depois de o show terminar". Completou, dizendo estar cansado do estilo que vinham empreendendo: "aquele conjunto bonitinho, que fazia gracinhas, não existe mais. Ninguém se diverte mais nos nossos shows, as pessoas vivem, vibram junto conosco". Influenciado pelo rock internacional, acreditava ser o ritmo "um modo de vida, um movimento que abre a cuca das pessoas, elevando o espírito e fazendo com que fiquem mais próximas de Deus". (Calado, 1995, p. 297).

No cenário internacional, as bandas de heavy metal e rock progressivo começavam a ganhar espaço.

No Brasil, cada vez mais, aumentava o número de jovens amantes desse tipo de música. Apesar disso, o contato com informações dos ídolos era muito pequena e não existia, por parte dos meios de comunicação nacional, apresentação das músicas desse tipo de rock.

\footnotetext{
Nesse sentido, as informações que aqui chegavam sobre, por exemplo, o emergente punk-rock de Londres e Nova York eram poucas e, muitas vezes, desencontradas. Como bem aponta a socióloga Helena Abramo, em Cenas Juvenis, o cultivo de tendências musicais pouco divulgadas pela mídia e a procura de discos raros de conjuntos estrangeiros se davam através de encomendas em lojas especializadas, com cotização para comprá-los ou reunião em casa de amigos para ouvir ou gravar. ${ }^{102}$
}

\footnotetext{
${ }^{101}$ CORRÊIA, 1989, p. 27.

102 CARMO, 2001, p. 121.
} 
De forma geral, eram cultivados dois estilos de rock'n'roll no nosso país: "o progressivo, mais vanguardista, cujo representante máximo era o Pink Floyd; o heavy metal, que, como o nome diz, trata-se de um rock mais pesado, barulhento, guitarras estridentes, como o do Led Zeppelin" (Carmo, 2001, p. 121). No Brasil, cinco nomes se destacam: Raul Seixas, Rita Lee, Made in Brazil, Secos \& Molhados e Os Mutantes.

Os Secos \& Molhados surgiram no ano 1974, ganham repercussão por conta de suas apresentações, baseadas nas extravagantes maquiagens e nas expressões corporais.

Um ano depois, o grupo acaba por conta de desentendimentos entre seus componentes. Apesar de seu fim, a carreira solo de seu líder, Ney Matogrosso, perdura até os dias de hoje.

Mas o Brasil já dava seus primeiros passos com relação à formação de um rock genuinamente nacional, graças a importação dos discos das bandas internacionais. Como bem aponta Renato Ortiz"103, "ao importarmos um produto cultural não importamos apenas objetos e mercadorias, mas também todo um complexo de valores e de condutas que se acham implicados nesses produtos" (Ortiz, 1999, p. 193).

Esses novos valores foram absorvidos pela cultura local. Em alguns pontos, absorvidos, em outros deram "asas" a novas manifestações culturais da juventude a partir do final da década de 1970.

Enquanto isso, a nossa juventude era "bombardeada" por outros ritmos americanos.

\subsection{A JUVENTUDE NOS EMBALOS DE SÁBADO À NOITE}

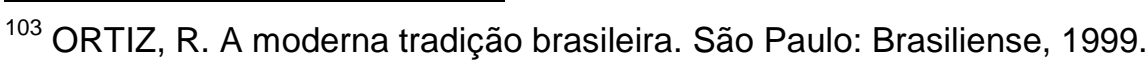


No final da década de 1970, o nosso cenário musical "embarcava" em um movimento bem diferente do crescente rock progressivo ou do punk inglês. Estávamos inseridos na Era das discotecas. A música disco era a mais nova fórmula no mercado americano para conquistar o gosto dos jovens por todo 0 mundo.

A indústria cultural opera, nesse tipo de movimento, a partir de formulações de marketing e campanhas publicitárias (incluindo os famosos jabás - compra de horários na programação radiofônica para que a música seja colocada repetidamente - e também das inserções televisivas). Claro que não podemos ser ingênuos em pensar que o mercado fonográfico vai tentar manipular seus consumidores, impondo-Ihes produtos que esses iram comprar sem reclamar.

O mercado trabalha através de tendências, por meio de dados e pesquisas, com um planejamento minucioso. Neste caso, houve uma junção das vendas de discos com o cinema, por exemplo. A disco-music tinha como premissa a dança. A música era irrelevante em comparação à batida e os movimentos que deveriam ser feitos. Criaram-se novos espaços para os amantes desse estilo. Lá eles poderiam se encontrar e se reconhecer através dos passos bem marcados e delimitados. Temos a formação de uma tribo baseada em uma música dançante e despreocupada, sem nenhum tipo de vinculação política e que não representava nenhuma linha de pensamento específica.

\begin{abstract}
Essa música era feita basicamente para dançar. "Para quem viveu os últimos anos da década de 1970, a disco-music era uma coisa (uma manifestação cultural? Um golpe de publicidade extremamente bemsucedido? Alucinação coletiva?) alastrada, inegável e maciça. Como um furação, a epidemia disco varreu a terra e se instalou pelos quatro cantos, uma ocupação cultural rápida e abrangente como não se via desde o tempo dos Beatles. As multinacionais do disco nunca pensaram em faturar tanto. Somente nos EUA a indústria fonográfica movimentou 8 bilhões de dólares e conseguiu seduzir os jovens do mundo inteiro que entraram nas pistas de dança das casas noturnas - chamadas discotecas, com o corpo e a alma em movimento. ${ }^{104}$
\end{abstract}

${ }^{104}$ GUERREIRO, A. S. Retratos de uma tribo urbana: rock brasileiro. dissertação (mestrado). Faculdade de Filosofia, Letras e Ciências Humanas da Universidade de São Paulo, 1991, p. 45. 
O representante da disco-music no Brasil foi o grupo As Frenéticas, que lanço seu LP em 1977. Para Ana Maria Bahiana ${ }^{105}$, elas exprimiam tudo o que aquele momento era para a juventude. "aquelas seis meninas tão díspares entre si, tinham a aura exata, davam justa impressão de terem saído de sua própria platéia, do centro da pista". Ainda por cima, "encarnavam todas as aspirações e fantasias de quem estava do outro lado, ali embaixo" (Bahiana, 1980, p. 250).

Claro que, para uma sociedade conservadora, o comportamento do grupo não era dos mais aceitáveis.

Uma matéria publicada no Jornal Metrô News de São Paulo chamava-as de "cupins biônicos que roerão os pilares da nossa sociedade, incitadoras da juventude, transformando nossos filhos em vesúvios de sexualidade. ${ }^{106}$

No período de sucesso da música disco, gerou-se um debate sobre a sua possível derivação do rock. A mídia divulgava que os roqueiros se dividiam ao falar sobre a disco-music. "alguns viam naquela música uma armadilha da indústria cultural para abafar o protesto punk, pois acreditava que aquele música sintetizada, absolutamente industrializada, para os que cultuavam o aspecto político do nascente movimento punk, a discoteca "representava um conformismo desumanizante, a imposição de uma forma rígida e inexpressiva que foi imposta às massas por uma diabólica conspiração" (Reportagem do Jornal do Brasil de 23 de janeiro de 1979 apud Carmo, 2001, p. 46).

O debate foi esquecido tão rapidamente quanto a disco-music. $\mathrm{O}$ movimento foi rápido e trouxe resultados negativos para a indústria fonográfica. Em seu primeiro momento, a discoteca foi absorvida pelo público jovem, mas como seu formato era extremamente limitado, acabou sendo classificado como "brega". O alto consumo dos discos causou um processo inflacionário no valor da produção fonográfica, um dos motivos para a recessão no mercado de discos no mundo.

\footnotetext{
${ }^{105}$ BAHIANA, A. M. MPB nos anos 70. Rio de Janeiro: Ed. Civilização Brasileira, 1980.

${ }^{106}$ CARMO, 2001, p. 46.
} 
O mercado musical não possuía ainda, nesse momento, mecanismo para recriar novos movimentos de juventude. A disco-music era um produto efêmero, assim como é todo produto cultural massivo. Ele deve ter como característica a descartabilidade. Isso ocorre para que a indústria possa recriar novos produtos e lucrar ainda mais.

A indústria fonográfica não esteve preparada para o enfraquecimento da discoteca, pois com o fim de sua fórmula, nenhuma outra - de tamanha magnitude - foi empregada.

Enquanto esteve no auge, a disco-music foi tratada como deveria pela mídia impressa: um movimento estrondoso, mas que era desprovido de qualquer mensagem, um simples produto cultural. Mas as reportagens de época demonstram o caráter mercadológico do movimento, enfatizando, principalmente, As Frenéticas como os novos ídolos do país.

\subsection{FAÇA VOCÊ MESMO: A HORA DO MOVIMENTO PUNK}

A música de estilo mais comercial, que era a discoteca, "embalava" alguns jovens no Brasil, enquanto outros se tornavam adeptos do insipiente rock que nascia por aqui. Mas uma grande parte consumia a produção não-nacional. Nesse período de importação da produção musical, a juventude brasileira teve contato com o movimento punk inglês.

A sua origem está relacionada a jovens britânicos, inseridos no contexto de crises econômicas no pós Segunda Guerra mundial. Essa juventude, inserida nas classes mais baixas, advinda de famílias operárias inglesas e externava sua indignação através de um comportamento agressivo que se fazia presente em suas músicas. 
Existia um clima geral de revolta e toda essa situação contribuiu para a criação de um novo estilo. Como nos afirma Paula Gonçalves ${ }^{107}$, a juventude começou a celebrar a destruição e "expressavam nas suas músicas o desespero, o sub-emprego, a falta de perspectiva e as escassas possibilidades de se chegar a melhores condições de vida e trabalho". (Gonçalves, 2005, p. 66). A banda pioneira nesse estilo foi o grupo inglês Sex Pistols, que pregava, entre outras coisas, a destruição e a anarquia.

A palavra de ordem era "do-it-yourself", "faça sua banda de rock", "faça suas próprias revistas", "espalhe a palavra punk". O número de bandas começou a proliferar: The Clash, The Damned, The Stils, Sham 69, Uk Subs e outras. A atitude era proposta e acionada pelo grupo Sex Pistols que com sua postura e música, estimulava a aparição de mais bandas. ${ }^{108}$

A filosofia das bandas era baseada em dois princípios: o da transformação social, alcançada pela "destruição" dos modelos atuais da vida social; e o niilismo encarnado em várias letras musicais referentes ao movimento - o "no future". Existia um enorme desapego ao sentido e ao porquê das coisas.

Esses jovens estavam fora do circuito de consumo. Por isso, fabricavam suas próprias roupas e faziam seus ensaios nos lugares mais improvisados. A especialização nos acordes também era precária, já que não possuíam conhecimento musical evoluído, o que não impediu que fizessem canções de extrema importância, embebidas em crítica social e que criavam, a partir do protesto, toda uma sociabilidade.

O motivo pelo qual um novo tipo de música foi capaz de adquirir contorno de um Movimento Cultural reside no fato de que o punk rock antes de propor um novo conteúdo musical, propunha uma forma mais contundente, novos meios de produzi-lo, fazê-lo circular e renová-lo. O punk rock mexeu no cenário profissional e seletivo que dominava a musica até então, criando um circuito underground mais democratizado, que contava apenas com a vontade que cada um tinha de expressar-se e participar da cena. (Gonçalves, 2005, p. 1993, p. 32-33)

\footnotetext{
${ }^{107}$ GONÇALVES, P. V. Ser punk: a narrativa de uma identidade jovem centrada no estilo e sua trajetória. Dissertação (Mestrado). Faculdade de Educação da Universidade de São Paulo, 2005. ${ }^{108}$ GONÇALVES, 2005, p. 66.
} 
O punk deu ao jovem a oportunidade de se posicionar diante do debate político. A manifestação cultural tinha como preceito quebrar a política institucionalizada através de pequenas ações, um engajamento pautado na mudança de postura que, junto com as letras e canções, conduzia a um protesto dentro de seus espaços coletivos, "utilizando seu visual, seus rituais coletivos como espaço para expressar o lamento de revolta contra a forma que estaria organizada a sociedade". (Gonçalves, 2005, p. 67)

Com o seu crescimento, o punk começou a ser visto em todas as partes do mundo. Os jovens brasileiros se sensibilizaram com a proposta e aderiram ao pensamento da juventude inglesa. Mas apesar dessa influência, aqui, o punk teve características diferenciadas.

A periferia paulistana foi o berço do movimento no Brasil, a partir do ano de 1978. Seu crescimento foi rápido, chegando a outras periferias no Brasil, além de ser recebido também pela classe média.

Até seu crescimento no começo da década seguinte, é com o jovem proletariado brasileiro que o movimento punk cresce.

Com relação ao contexto de sua criação, o final da década de 1970 mostrava um desgastado Regime Militar em meio a uma crise mundial. A repressão política ainda fazia parte do nosso quadro político. Tentando salvar a imagem do país, o Governo "esqueceu" de olhar para os problemas internos, como o desemprego e o aumento da desigualdade social. A sociedade estava indignada. Como afirma Paula Gonçalves, as palavras de ordem eram: passeata, protesto, revolta e exploração. De tão fortes, acabaram inspirando a formação de bandas de punk, que, em seus nomes, já mostravam sua insatisfação com a situação do país.

Essas palavras, por algumas décadas, foram usadas como nomes das bandas punks brasileiras. As primeiras tinham designações como: Passeatas, Desordem e Regresso, Dever de Classe, Tropa Suicida, Hino Mortal, Al-5, Cólera, Ação Direta, Pátria Amada. Nossos jovens tinham todos os elementos para se identificarem com as propostas lançadas pelos jovens ingleses e usaram o punk como uma forma de manifestar 
seus descontentamentos, expressar posições políticas favoráveis à esquerda e à mudança do regime do governo vigente. ${ }^{109}$

O movimento punk se apoiou nas gangues de amigos da periferia paulistana. Nesses grupos foi fácil a sua proliferação devido à sua organização, as atividades realizadas em conjunto e a criação de espaços de lazer e sociabilidade. Suas roupas demonstravam toda a agressividade do movimento: tons escuros e masculinos, ressaltando traços de força, luta e guerra. Um estilo agressivo, no qual as "garotas usavam maquiagem exagerada, meias furadas ou feitas de rede de pesca, colar de corrente e cadeado (...) como resultado teve a proliferação do couro, correntes e roupas esfarrapadas"(Carmo, 2001, p. 126).

A música, pautada na situação do país, falava dos problemas que afligiam a população brasileira, como a fome, miséria e o desemprego. Apesar de conter vários outros elementos, principalmente o comportamental e de postura política, foi mesmo através das bandas que o movimento punk se fez no mundo inteiro. A postura de seus cantores foi copiada e adaptada, mas mantinha seus elementos principais: o caráter anárquico e reflexivo do movimento.

Podemos verificar, portanto, que existe uma interação permanente entre as várias culturas do mundo, através da reciprocidade de influências. Aqui, independe do idioma falado, por meio das mídias (rádio, TV, cinema), as distâncias são diminuídas e os valores são incorporados, com a construção de novos a partir de um código comum ${ }^{110}$.

Essa interação cultural possibilitou a formação de várias bandas nacionais que, bem antes aparecimento do movimento de forma comercial, já faziam bastante sucesso no Nosso país. As periferias e guetos nacionais eram consumidores assíduos dos sucessos do punk rock.

As primeiras bandas datam de 1978 e tinham nomes como Al-5, Condutores de Cadáveres, Restos de Nada. No ano de 1982, quando a imprensa nacional tomou conhecimento do ressurgimento do movimento

\footnotetext{
${ }^{109}$ Idem, p. 68.

${ }^{110}$ CORRÊIA, 1989, p. 29
} 
no mundo, aqui já existiam mais de 20 bandas se apresentando em shows periféricos. ${ }^{111}(72)$

A partir do ano de 1981 começaram a surgir festivais de música punk. Apesar de existir uma grande tensão entre os jovens do ABC e de São Paulo, os encontros possibilitavam a troca de informações e a apresentação de várias bandas.

Mas a repercussão nacional dos movimentos através da mídia só foi proporcionada pela participação de jovens de classe média no punk. Os meios de comunicação de massa possibilitaram a ascensão do movimento e conseguiram "quebrar" um pouco da imagem negativa que existia com relação às suas manifestações.

O espírito punk em sua adaptação no Brasil, talvez tenha sido reforçado em alguns aspectos que só poderiam ser vistos no contexto inglês - até mesmo, por conta de informações incompletas sobre esse tipo de cultura pelos jovens brasileiros adeptos. A violência, que era uma forma de protesto contra a sociedade, foi vista aqui, algumas vezes, de forma "esvaziada". Eram freqüentes as brigas nos shows que, aliadas ao modo de se vestir e ao jeito de dançar (exaltado e agressivo), fizeram com que a sociedade os julgasse como violentos, por isso mesmo, existia uma grande vigilância da polícia em qualquer manifestação.

Já no começo da década de 1980, os punks paulistanos concederam entrevista para a mídia nacional, falando do seu modo de vida e sobre suas reivindicações. De acordo com Antônio Bivar ${ }^{112}$, eles queriam mostrar que tinham opiniões críticas - e de esquerda - sobre tudo o que acontecia na sociedade brasileira.

Essa "abertura" para o movimento punk foi ocasionada pela participação da classe média e pela mercantilização de sua produção musical. Na Inglaterra, o Sex Pistols já começava a vender muitos discos. Apesar de muitos meios de

${ }_{111}^{11}$ GONÇALVES, 2006, p. 72.

112 BIVAR, A. O que é punk? São Paulo. Abril, 1983, p. 100. 
comunicação "boicotarem" seu trabalho, era impossível refrear o sucesso alcançado pelo seu jeito anárquico de cantar o mundo. Por conta desse aspecto mais mercadológico do movimento, muitos acharam que seria o fim do punk e que sua mensagem seria englobada pela "máquina" capitalista.

\begin{abstract}
A absorção pela indústria cultural, sua entrada nas classes média e alta através da moda e sua musicalidade incorporada pelas novas ondas de bandas fazem com que reiteradamente se decrete o fim do punk. Esta afirmação - "o punk morreu" - perseguirá o punk, como se fosse um estigma e, enquanto ele existir servirá para atestar ou questionar sua falta de legitimidade. ${ }^{113}$
\end{abstract}

O crescimento de ritmos de influência punk - mas de caráter estritamente comercial - como hardcore, e o aparecimento do new wave e do Rock dos anos 80 reforçaram esse pensamento.

O processo de massificação do movimento punk leva uma mercantilização da rebeldia - processo esse, que também pôde ser verificado no período da contracultura. Os punks começaram a aparecer nas novelas da Rede Globo, como estereótipo de filho rebelde.

Outro aspecto marcante é a questão do estilo e da moda punk. Em tese, tem sua base nas mudanças ocorridas com os jovens durante a década de 1970. Temos, nesse período, o enfraquecimento do jovem universitário como referência para a cultura jovem e a quebra da relação entre a cultura alternativa e o protesto ao sistema. Para completar, as classes mais pobres começam a ter acesso ao lazer e ao consumo.

\begin{abstract}
Paralelamente às crises econômicas enfrentadas na década de 1970, descortina-se uma nova configuração do universo juvenil: a crise do espaço universitário como significativo para a elaboração das referências culturais, o enfraquecimento da noção de cultura alternativa como modo de contraposição ao sistema e a emergência de uma intensa vivência, por parte dos jovens das camadas populares, no campo do lazer ligado à indústria cultural. ${ }^{114}$
\end{abstract}

\footnotetext{
${ }^{113}$ GONÇALVES, 2006, p. 73.

${ }^{114}$ ABRAMO, H. Cenas juvenis: punks e darks no espetáculo urbano. São Paulo: Scritta, 1994, 82.
} 
A partir desse momento, os jovens começam a ser articular em torno do estilo. "São fenômenos que se desenrolam justamente no cruzamento dos campos do lazer, do consumo, da mídia, da criação cultural e lidam com uma série de questões relativas às necessidades juvenis desse momento" (Abramo, 1994, 82).

Kênia Kemp ${ }^{115}$ acredita que esse pensamento nasceu nos anos 1960. Foi lá que o jovem pensou em inscrever no corpo toda a lógica da cultura na qual estava inserido. A vestimenta passou a ser usada com meio de comunicação, algo pra reforçar a sua identidade. Seja através de camisetas e jaquetas com frases, ou no uso de faixas e bandanas na cabeça, o que a juventude queria era um meio de reforçar o estilo escolhido.

Assim como esses jovens da década anterior, os punks sentiam a necessidade de consumir, já que o pertencimento só era alcançado através do consumo.

A juventude percebia a fragmentação da vida social, ocasionada pelo individualismo moderno, contrário ao sentimento de união dos jovens. Compartilhar das mesmas roupas, dos mesmos discos, dos mesmos locais, era participar de um elo perdido, quase instintivo de identificação. Ao vestir roupas rasgadas e pintar os cabelos de cores extravagantes pensava-se, primeiro, em se sentir igual, buscar o pertencimento e, em segundo, de rechaçar as outras culturas, ditas oficiais de grupos de jovens já institucionalizados pelo Estado ou, simplesmente, mercantilizados pela indústria cultural. Essa juventude punk tinha:

A necessidade de construir uma identidade em meio à intensa complexidade e fragmentação do meio urbano, e que se reflete no peso sinalizador e na velocidade das modas; a necessidade de equacionar os desejos estimulados pelos crescentes apelos de consumo e as possibilidades de realizá-los; a necessidade de situar-se frente à enxurrada de informações veiculadas pelos meios de comunicação; a

\footnotetext{
${ }^{115}$ KEMP, K. Grupos de estilo jovens: o rock underground e as práticas (contra) culturais dos grupos punk e trash em São Paulo. Dissertação (Mestrado). Faculdade de Antropologia da Universidade Estadual de Campinas, 1993, p. 178.
} 
necessidade de encontrar espaços de vivência e diversão num meio urbano modernizado ainda pobre de opções e segregacionista, adverso aos jovens com baixo poder aquisitivo; e a necessidade de elaborar a experiência da crise, com as dificuldades de articular perspectivas de futuro para si próprios e para a sociedade. ${ }^{116}$

Esses jovens desejavam um estilo próprio e criavam seus próprios bens culturais. Queriam, desse modo, escapar da massificação da produção e da imposição da indústria da moda.

Buscavam, assim, uma distinção, algo que reforçasse seus elementos e influenciaram muitas outras tribos que apareceram durante as décadas seguintes no Brasil e no mundo.

Os punks foram os primeiros desses grupos a aparecer nas cidades brasileiras, e assim pode-se dizer que surgiram como a primeira manifestação das novas questões colocadas para essa geração de jovens urbanos. O seu surgimento e o choque por eles provocado desencadearam o aparecimento de diversos outros grupos ou tribos. Mas foram os punks que lançaram a pista, introduzindo um novo modo de manifestação e atuação, estimulando assim outros grupos juvenis a assumirem e expressarem suas identidades distintivas. ${ }^{11}$

Como bem aponta Kênia Kemp, usar o estilo para se expressar passou a proporcionar, em pouco tempo, uma subdivisão de estilos. "Pequenas ou grandes diferenças entre os jovens foram sendo expressas em seus usos estéticos, como forma de aproximações e distanciamentos". (Kemp, 1993, p. 179).

Dentro do estilo punk existiam vários outros estilos. E esses jovens se diferenciavam através da roupas.

Apesar das pequenas diferenças entre os "guetos", a "sociedade alienada de consumo" era combatida através do comportamento e das vestimentas. $\mathrm{O}$ combate a essa ideologia era feito por toda essa constituição de estilo.

\footnotetext{
${ }_{116}^{116}$ ABRAMO, 1994, p. 82-83.

${ }^{117}$ Idem, p. 83.
} 
Quanto aos grupos de estilo underground, o que está sendo colocado em primeiro lugar em seu coro contra o "sistema massificante", a "sociedade alienada de consumo", seria a tentativa de se colocar contra a ideologia do consumo que se estabeleceu com a música jovem (o rock) e que serve como disseminador social. ${ }^{118}$

Acontece que esse estilo acaba sendo reproduzido pelos meios de comunicação de massa e "seus elementos simbólicos passam a ser interpretados como mais uma série de produtos, que podem ser consumidos para expressar não uma discordância, mas um charme diferenciador". Desse modo, acontece toda uma ressignificação da cultura punk.

Mas temos que reconhecer que isso ajudou e ajuda na própria repercussão do movimento. A filosofia punk foi disseminada para todo o mundo através das informações dos medias e da produção em massa de discos do Sex Pistols.

O uso das roupas do underground foi mercantilizado pela indústria da moda, mas continuou ainda como forma de identificação. Pode ser que fora do seu contexto e dentro de uma lógica de consumo, mas ainda sim, identificando jovens que possuem o mesmo estilo e ouvem músicas das mesmas bandas.

Se no final dos anos 1970 o punk se resumia a pequenos guetos, sua popularização na década seguinte foi marcada por sua entrada no "sistema de consumo" capitalista.

Na década de 1980, o punk vai ser uma das influências mais fortes para a formação de todo um circuito alternativo de bandas. O Rock brasileiro desse período tem sua base nesse movimento.

\subsection{ANOS 80: BRASIL DE PLANOS E DESENGANOS}

${ }^{118}$ KEMP, 1993, p. 179. 
A década de 1980 foi marcada pelo processo de redemocratização do Brasil. Mas também presenciamos várias crises econômicas, com altos índices de inflação e três planos econômicos que tentaram reestruturar o país.

Quando João Baptista Figueiredo foi empossado em 1979, a sociedade esperava pela tão sonhada transição para a democracia. Toda a popularização, alguns anos mais tarde, se mobilizou para que o país pudesse adentrar no regime democrático. É nesse contexto que nasce a campanha das Diretas Já.

\begin{abstract}
A mobilização popular pró-diretas iniciou-se timidamente em meados de 1983. Na Campanha pelas Diretas, em cada cidade do país o povo reagia com entusiasmo, mobilizado pela oposição. Diversas associações civis aderiram ao evento, como a Ordem dos Advogados do Brasil (OAB) e os grandes jornais. ${ }^{119}$
\end{abstract}

Ainda, de acordo com Paulo Sérgio do Carmo, artistas, jogadores de futebol e pessoas das mais diferentes áreas e classes sociais transformaram os comícios em grandes acontecimentos políticos e culturais.

No começo do ano de 1984 as concentrações se tornaram maiores. Ganharam apoio da imprensa e de setores organizados da sociedade civil. Nas principais capitais do país, mais de 500 mil pessoas participavam das passeatas, vestidas de amarelo - a cor da Campanha - expressando sua vontade em votar para presidente.

Apesar dos esforços da população e dos políticos que apoiavam o movimento, as Diretas não conseguiram no Congresso os votos suficientes par a sua aprovação. Desse modo, Tancredo Neves foi escolhido, de forma indireta, para concorrer ao cargo. Mas com sua morte, José Sarney assumiu a presidência.

O desencanto tomou conta da população. O país era marcado pela corrupção e os crimes que envolviam os políticos não ganhavam a punição

${ }^{119}$ CARMO, 2001, p. 143 
necessária. Os militares tinham deixado o país em crise e, nem mesmo, um processo de redemocratização conseguiu reverter esse quadro.

Esse sentimento foi transformado em revolta, em alguns casos. As greves foram comuns nessa década. Em 1985 aparecem as grandes manifestações - de nível nacional - nesse sentido.

\begin{abstract}
Em setembro de 1985, setecentos mil bancários promoveram a primeira greve de fato nacional da história do país. Sem piquete, houve paralisação total em alguns lugares e parcial em outros. Em 1988, soldados da PM e do Exército invadem a Companhia Siderúrgica Nacional, em Volta Redonda, o que resulta na morte de três operários grevistas. ${ }^{120}$
\end{abstract}

No campo econômico, o Brasil sofria com uma inflação de $46,58 \%$ em 1985. Em fevereiro do ano seguinte, entra em vigor o plano cruzado. Entre suas principais medidas, podemos destacar o corte de 3 zeros da moeda; a instituição de um gatilho salarial - que seria acionado quando a inflação chegasse a $20 \%$ e; congelamento de preços. Acontece que houve começou a ser cobrado um ágio em cima das mercadorias e o país verificou um desabastecimento nos supermercados.

No ano de 1987 foi instituído o Plano Bresser, que também não conseguiu resolver os problemas do país. No ano de 1989, surge o plano Verão que, novamente, foi ineficaz para contornar nossos problemas financeiros. "Ao final do governo Sarney, o Brasil bateu recorde de inflação com taxa anual de 1.782\%". (Carmo, 2001, p. 157).

O final da década é marcado por um progresso: a promulgação da Carta Magna, que retiraria todas as arbitrariedades impostas pelos militares na Constituição de 1969.

No campo musical, a indústria fonográfica e os produtores ressaltam ainda mais o aspecto massivo (que já vinha se consolidando na década anterior), mas,

${ }^{120}$ Idem, p. 157. 
como explica Eduardo Vicente ${ }^{121}$, também devemos acrescentar "a recusa explícita aos principais pilares do pólo da MPB, como a sofisticação dos códigos, o posicionamento político e o projeto modernista" (Vicente, 2001, p. 102). Ocorre um processo de legitimação do consumo no Brasil.

A figura do empresário ganha mais destaque, primando pela infra-estrutura de seus artistas e indo ao encontro do Marketing.

\begin{abstract}
Além do compositor, outra figura que ganha destaque no período é a do empresário. Nomes como o de Manuel Poladian, por exemplo, que empresariou nas décadas de 80 e 90 artistas como RPM, Jorge Ben Jor e Roberto Carlos, tendem a ganhar maior relevância não só pelos seus investimentos na promoção de seus contratados, mas também pela estrutura técnica e profissional que passam a fornecer a seus shows, incluindo modernos sistemas de som e iluminação. ${ }^{122}$
\end{abstract}

Pautados nas novas estratégias de marketing - para atrair público para os grandes shows - e na popularização e massificação das bandas, a indústria fonográfica e a produção musical brasileira tentava superar a crise do setor de discos nessa década.

O modelo adotado para a promoção de bandas nacionais foi baseado na estrutura que os grandes astros pop tinham lá fora. Esses cantores tiveram grande sucesso no mundo, inclusive no Brasil.

\title{
3.5 UMA PAUSA PARA O POP
}

A década de 1980 marca o sucesso de dois grandes astros pop: Michael Jackson e Madonna. O primeiro, já tinha começado sua carreira na década de 1970, em uma banda com os irmãos, chamada Jackson's Five. Tentou carreira

\footnotetext{
${ }^{121}$ VICENTE, E. Música e Disco no Brasil: a trajetória da indústria nas décadas de 1980 e 1990. Tese (Doutorado). Escola de Comunicações e Artes da Universidade de São Paulo, 2001.

${ }^{122}$ Idem, p. 126.
} 
solo pouco tempo depois, mas voltou para o grupo, voltando definitivamente a cantar sozinho no final dos anos 70 .

Até então, a música Black americana era restrita a "guetos" e bairros negros. Michael Jackson popularizou o ritmo através de Off the Wall. No ano de 1980, seu disco foi premiado com o Grammy.

No final de 1982 o artista lança o álbum Thriller, até hoje, o disco mais vendido da história, com 104 milhões de cópias. Estava consolidado um novo modo de lidar com o público. A indústria fonográfica utilizava elementos do marketing para descobrir as necessidades dos jovens e empregava elementos de imagem completamente sedutores. O videoclipe foi essencial para que Michael Jackson pudesse alcançar tanto sucesso. Como aponta Guilherme Bryan ${ }^{123}$ sobre o poder desse instrumento: "se o rock and roll havia conseguido unir os jovens do mundo inteiro em torno de uma expressão alternativa, o videoclipe firmou-a num estilo de vida para a divulgação publicitária de bens de consumo" (Bryan, 2005, p. $85)$.

Quando relaciona a música à imagem do artista, através do videoclipe, fica muito mais fácil para a indústria cultural investir em produtos que remetam ao músico ou banda.

Outra característica do videoclipe é seu poder de relacionar um gênero musical ou uma música à figura do intérprete, tornando-a uma forma de propaganda do artista. Dessa forma, o clipe ajuda à constituição de um "star system" audiovisual, consagrando celebridades. Seria, por exemplo, impossível imaginar fenômenos musicais como Michael Jackson e Madonna sem o apelo hipnótico dos clipes. ${ }^{124}$

Ao lado de Michael Jackson temos o nascimento de outra estrela que marcou essa década. Madona Louise Ciccone, influenciou toda a cultura pop mundial. "Foi a mais vendida e mais discutida das cantoras populares, uma das estrelas mais proeminentes do videoclipe, aspirante a atriz de cinema e, acima de

\footnotetext{
${ }^{123}$ BRYAN, G. Videoclipe brasileiro: história, características e internacionalidade. Dissertação (Mestrado). Escola de Comunicações e Artes da Universidade de São Paulo, 2005.

${ }^{124}$ Idem, p. 86.
} 
tudo, superstar pop" (Kellner, 2001, p. 335). Foi alvo de muitas controvérsias. Se, de um lado, era amada por seus fãs, como ícone de imagem da moda, por isso mesmo, exemplo de como se vestir e comportar, de outro lado, era considerada pela crítica, símbolo máximo do consumismo, o ápice da deturpação da música pela imagem, das letras para a insinuação sexual.

Os anos 1980 foram um momento de reformulação da identidade jovem. Sua aparição foi "bombástica", "seus primeiros videoclipes e shows transgrediam as fronteiras do trajar tradicional, e ela se entregava a um comportamento sexual desinibido, subvertendo os limites do "apropriado" para a mulher" (Kellner, 2001, p. 341).

Seu comportamento escandaloso poderia não ser tão "subversivo" como o de outras bandas - como alguns punks, por exemplo -, mas ela tinha a sanção da indústria cultural e circulava livremente pela classe dominante. Deu aos jovens a noção de que a identidade é algo completamente mutável, e a imagem é que dava o tom a essas mudanças.

(...) Madonna sancionava a rebeldia, o inconformismo, a individualidade e a experimentação com um jeito de vestir e de viver. Suas constantes mudanças de imagem e identidade preconizavam a experimentação e a criatividade nesses campos. Suas transformações às vezes drásticas em matéria de imagem e estilo indicavam que a identidade é um construto, algo que, produzido por nós, pode ser modificado à vontade. $\mathrm{O}$ modo como Madonna usava a moda na construção de sua identidade deixava claro que a aparência e a imagem ajudam a produzir o que somos, ou pelo menos o modo como somos percebidos e nos relacionamos. ${ }^{125}$

A cantora trouxe à tona o problema da identidade, mostrando seu caráter de "construção" e sua possibilidade de ser alterada. Foi uma artista completa, enveredando pelos campos da dança, música, passarelas, videoclipes e se tornou uma das empresárias mais bem sucedidas dos Estados Unidos.

Sua imagem foi trabalhada e retrabalhada. Se ela começou sendo um objeto sexual, transformou-se na artista dos videoclipes, passando até pelo

${ }^{125}$ KELLNER, 2001, p. 341. 
cinema. As letras fáceis foram trocadas por outras mais elaboradas, falando de amor e investindo nas tecnologias visuais. Mas do que artista, foi uma personagem, foi ídolo, foi exemplo. Suas mudanças ocorriam de acordo com os anseios de uma juventude ávida a quebrar padrões, normas e confrontar a sociedade. Ela captou as mudanças culturais, e através de sua popularidade conseguiu disseminar modelos incorporados pelo seu público.

Os cabelos de Madonna mudaram do loiro encardido para o loiro platinado, para o negro, para o castanho, para o ruivo e para suas infinitas variações. Seu corpo passou do suave e sensual ao charmoso e esbelto, à máquina sexual rija e musculosa, ao tecnocorpo futurista. A roupa e a moda que ostentava mudou do barato espalhafatoso para a alta-costura; para a tecnocostura radical, para o lésbico-sadomasoquista, para o pasticho pós-moderno da moda vale-tudo. Novas imagens e nova identidade para todas as ocasiões e todas as épocas. ${ }^{126}$

O fenômeno só pode ser entendido ao pensarmos nas estratégias de marketing feitas por Madonna. Ele vendia muito bem sua imagem. Soube incorporar os anseios do público e transformá-los em canções. Andou por todas as "subculturas" jovens e pegou um pouco de seus elementos para participar de seus espetáculos. Soube construir bem sua relação com a imprensa, através de Relações Públicas e Assessores. Contratou publicitários para melhorar ainda mais sua imagem.

Desde o começo, todos os seus movimentos foram cercados de publicidade e, ano a ano, proliferaram referências a Madonna na cultura da Mídia. Na verdade, uma pesquisa no banco de dados Nexis com os termos "Madonna e pop", no período de 1984 a 1993, rendeu mais de 20 mil citações! Portanto, um grande sucesso de marketing e propaganda. ${ }^{127}$

Madonna e Michael Jackson inauguraram uma nova forma de atrair os jovens. Esse modelo foi utilizado por bandas e cantores em todos os locais do mundo. O marketing começou a fazer parte também da música. E esse "feeling"

\footnotetext{
${ }^{126}$ Idem, p. 341.

127 Ibdem, p. 342.
} 
com a juventude influenciava também nas próprias composições. $O$ videoclipe também começou a ser utilizado freqüentemente, como forma de "vender" os artistas.

É claro que suas estratégias surgiram efeito. Os dois cantores eram pautas fáceis de aparecer na mídia.

\subsection{O BROCK - MÚSICA, POLÍTICA E GERAÇÃO COCA-COLA}

O rock brasileiro dos anos 1980 foi um dos movimentos musicais mais importantes para o país. Representou o renascimento de uma cultura da juventude, pautada em ídolos nacionais e que movimentou novamente o consumo da produção musical. O BRock teve diferentes vertentes, algumas que utilizavam somente os elementos do ritmo rock; outras que faziam discurso político e crítica social, e as que encaravam o Brasil através do humor.

De fato, a produção musical do período foi inovadora, criativa e inspirou a maior parte das bandas que nasceu na década de 1990. O sucesso desse período é tão marcante, que muitos dos grupos que participaram do movimento, ainda hoje sobrevivem no mercado.

3.6.1 Um som para a rapaziada: o início do Rock brasileiro dos anos 1980

O início da década de 1980 foi marcado, ainda, pela forte presença da MPB nos meios de comunicação. A indústria fonográfica nacional carecia de ídolos locais que fizessem aumentar as vendas de discos. Para atrair mais público para a música brasileira, foram feitos, nos anos de 1980 e 1981, novamente, os Festivais. Nesse período aparece uma surpresa em meio a canções de Oswaldo Montenegro e Guilherme Arantes: A Gang 90 e suas Absurdettes, com seu rock performático, fazendo o público torcer por seu hit Perdidos na Selva. 
A banda, que incorporava o estilo rock new wave ${ }^{128}$, veio sanar a necessidade de um rock com a cara do Brasil. O sucesso foi tamanho que, segundo Arthur Dapieve ${ }^{129}$, no ano de 1983, o grupo - que lançou um LP, tendo como carro-chefe a música Nosso Louco amor, trilha da novela global "Louco Amor" - teve um dos maiores sucessos comerciais do ano, com um compacto que vendeu mais de 100 mil cópias. (Dapieve, 1995, p. 25).

"Você não soube me amar" foi a música de mais sucesso do ano de 1982. A canção pertencia ao grupo carioca Blitz. Sua penetração com a juventude pode ser explicada por vários aspectos, já que "a música era tudo aquilo que as rádios não tocavam na época: linguagem coloquial, urbana, um pop muito BM feito, mais falado do que cantado" (Dapieve, 1995, p. 54).

Trazia o sotaque e a malevolência do carioca impressa na sua interpretação. A música se tornou uma coqueluche, tocada exaustivamente nas rádios nacionais, a banda se tornou famosa.

Pronto. Estava descoberta a pólvora. Ou,como diz Lobão, o falso óbvio. "Você não soube me amar" virou um sucesso. Era ouvida em todas as rádios, em todos os lugares, a qualquer hora do dia ou da noite. O estouro da canção levou a EMI-Odeon a renegociar o contrato com a Blitz, temendo perder sua galinha dos ovos de ouro para outra gravadora, e deu liberdade para que Evandro \& Cia, ainda em estúdio, fizessem o que desse na telha. Parecia um sonho. ${ }^{130}$

Apesar de todo o momento de redemocratização, a Blitz teve algumas de suas músicas censuradas. O seu estilo debochado não agradava todos os setores da sociedade. Claro que isso não impediu o seu sucesso mercadológico.

A indústria cultural soube utilizar muito bem da imagem do grupo até quando ainda foi consumido pelo público jovem. Um desses exemplos foi a utilização de Evandro Mesquita como peça para o mercado publicitário em uma propaganda da Pepsi com a cantora Tina Turner. A superexposição - ocasionada

\footnotetext{
${ }^{128}$ Estilo musical derivado do punk, só que de maneira mais sofisticada, primava pela sonoridade e não abusava de atitudes ofensivas.

${ }_{129}$ DAPIEVE, A. BRock: o rock brasileiro dos anos 80. Rio de Janeiro: Editora 34, 1995.

${ }^{130}$ Idem, p. 55.
} 
por suas inúmeras aparições nos meios de comunicação - fez com que a banda terminasse no ano de 1986.

Sem pensar no contexto de cada banda especificamente, devemos ressaltar é que, a partir de 1982, ganha novo impulso o nosso rock nacional. Influenciados pela Gang 90 e pela Blitz, jovens brasileiros começam a criar bandas de garagem e o circuito underground começa a crescer. Surge um público específico para o ritmo e isso, estimula a indústria cultural a mercantilizar o movimento.

O rock nacional renasceu de forma bem comercial, atrelado à gravadoras e com apoio de estratégias de marketing. Ele se valeu da espera da juventude nacional por ídolos aos quais pudessem se identificar. O movimento punk era muito setorizado e a MPB não conseguia contagiar a juventude nacional.

A Blitz e a Gang 90 descobriram a fórmula necessária para que o público jovem pudesse se reorganizar novamente, através dos espaços - as casas de rock brasileiro como o famoso Circo Voador - e também através do consumo, principalmente da produção fonográfica e dos produtos reforçados pela imagem das bandas na publicidade brasileira.

A mídia brasileira não fechou os olhos para esse movimento e investiu pesado em especiais e reportagens, alavancando o mercado editorial do setor, com publicações específicas para o público roqueiro com a Revista Blitz.

Outro fator importante é que o BRock atingiu as diversas classes sociais e não utilizava elementos de identificação como a contracultura e o punk. Seu vestuário era o mais diverso possível, incluindo também a moda do underground, mas não ela somente.

A falta desse elemento não impediu a identificação através dos gostos musicais, incidindo na formação de tribos específicas e que propiciou, também, o crescimento de várias bandas de garagem, impulsionando outros mercados pertencentes a indústria cultural, como o de instrumentos musicais. 
3.6.2 Enquanto isso no Planalto Central: política e canção.

Como pudemos perceber, a mídia começou a dar mais atenção para o rock nacional. Consolidavam-se os grupos e os eventos atraíam multidões de jovens ávidos por novas bandas e canções. Os conjuntos encabeçavam um movimento pós-punk e tinham referência no new wave americano. Distanciando-se de alguns grupos, outros tentaram enveredar pelo caminho da crítica social, claro que, valendo-se de seu status de entretenimento.

Essas bandas se negavam a fazer um rock "engraçadinho", distanciandose do estilo imposto pela Blitz e outros conjuntos como João Penca e Seus Miquinhos Amestrados.

\begin{abstract}
Mil novecentos e oitenta e quatro, o ano do Big Brother, de George Orwell, marcou o refluxo total da atividade punk em São Paulo. Em evidência, as tribos do pós-punk e da new wave. Bandas como Magazine, Ultraje a Rigor, Zero e a mod Ira! (que nasceu do punk subúrbio) conseguiram contratos com grandes gravadoras. Dentro de alguns meses, estariam liderando a ofensiva pós-Blitz do Rock Brasil. Com elas, surgiram em São Paulo novas casa de espetáculo - Napalm, Rose Bom Bom, Ácido Plástico, Any 44 e Madame Satã - onde os punks eventualmente se apresentavam. No underground, porém, o movimento prosseguia na medida do possível. ${ }^{131}$
\end{abstract}

Ao fazer esse tipo de crítica, esses novos ídolos se tornaram a voz da geração da década de 1980 .

$\mathrm{Na}$ capital federal, essas bandas se pautaram no movimento punk inglês. $\mathrm{E}$, ao contrário do que aconteceu no sudeste do país, o punk brasiliense era representado por jovens de classe média. Do final dos anos 1970, até início da década seguinte, acontece um crescimento de grupos musicais de influência punk, dos quais destacamos o Aborto Elétrico e a Plebe Rude. Esse dois grupos (e suas dissidências) conseguiram chegar na região sudeste e tiveram bastante retorno do público com suas música mais críticas.

${ }^{131}$ ESSINGER, 1999, p. 120. 
Se as gerações anteriores tinham sonhos utópicos e desejavam mudar as "estruturas sociais", a geração 80 queria mesmo era debater as questões reais e cotidianas, os problemas que o país atravessava e que as famílias atravessavam. Helena Abramo, em sua pesquisa sobre jovens punks, mostrou - através de entrevistas - que o jovem acreditava que o movimento trouxe uma liberdade musical maior, já que qualquer um poderia montar uma banda, sem a necessidade de ser um profissional da música. A juventude tenta chamar a atenção da sociedade para o seu discurso, que é pautado nas músicas de seus ídolos. Ouvir punk ou música que fala mal do país é uma forma de apresentar sua opinião e chocar a sociedade - especificamente a família - pelo fato de ter tal opinião.

Em Brasília, as bandas, formadas por jovens de classe média tinham, em comum, o nível cultural de seus participantes, normalmente filhos de professores universitários, com um alto nível de leitura e erudição.

Uma dessas bandas, o Aborto Elétrico, que possuía como alguns de seus componentes Renato Russo (Legião Urbana) e Dinho Ouro Preto (Capital Inicial), teve a proposta de fazer uma crítica social, levando em consideração elementos de juventude, como o protesto e a vontade de mudança. O movimento punk era tudo o que esses jovens necessitavam: atitude e rock'n'roll.

A música de grupos como a Legião Urbana "testava" a elasticidade do regime autoritário brasileiro. A década de 1980 marcava o período de abertura política e, por isso mesmo, a sociedade ainda não sabia que tipo de atitudes poderiam ser tomadas, sem que, agredissem os ditames do Estado.

No ano de 1979, o presidente Geisel estava começando um processo "lento, seguro e gradual" de abertura política, processo que enfrentava, dentro do próprio regime, a oposição de "bolsões radicais mas sinceros" de militares de extrema-direita. Nesse contexto, o novo rock brasileiro não somente o do pessoal de Brasília, mas também o da Blitz carioca e do Ultraje a Rigor paulista - iria testar a elasticidade da abertura. Para realmente florescer, o gênero precisa de ar puro da democracia. Não pode existir rock onde há censura. E circulação de idéias - mas que isso, a 
capacidade de ter idéias - era o forte em certos segmentos da capital federal. ${ }^{132}$

As idéias de jovens como Renato, Dinho e Herbet Viana (Paralamas do Sucesso) eram compartilhadas por outros músicos da "Turma da Colina". Uma espécie de "irmandade" das bandas de influência punk em Brasília.

Enquanto as festas de grupos punks de São Paulo e Rio tinham um caráter mais violento, os brasilienses tinham um comportamento contrário. Se existia alguma violência, com toda certeza, viria da Polícia Distrital que ainda possuía resquícios do Estado Repressor.

Renato Russo foi, por algumas vezes, alvo de policiais. Como uma resposta à repressão da polícia, o Aborto Elétrico, gravaria uma música chamada Veraneio Vascaína, cuja letra diria:

Cuidado, pessoal, lá vem vindo a veraneio/ toda pintada de preto, branco e vermelho/ com números do lado, e dentro dois ou três tarados/ assassinos, uniformizados/ veraneio vascaína vem dobrando a esquina. ${ }^{133}$

O Aborto Elétrico teve que mudar seu estilo e músicas devido ao próprio desgaste da música punk no Brasil e no mundo. A estratificação dos gostos dentro do movimento era enorme. Várias subtribos foram criadas, algumas, de caráter bem mais anárquico.

A banda, com suas músicas, proporcionou um novo momento para a juventude brasileira. Uma reflexão sobre o país, o marasmo da juventude, o imperialismo norte-americano e a fugacidade dos movimentos juvenis. A primeira letra escrita por Renato seria transformada em hino dessa geração, dita "cocacola".

\footnotetext{
${ }^{132}$ DAPIEVE, Arthur. Renato Russo: um trovador solitário. Rio de Janeiro: Relume-Dumará, 2000, p. 30-31.

${ }^{133}$ Idem, p. 34.
} 
A música era punk até a medula: protestava contra os Estados Unidos da América, falava em lixo comercial e industrial, em cuspir de volta: "Somos os filhos da revolução/ somos burgueses sem religião/ nós somos o futuro da nação/ geração coca-cola", era o refrão, daqueles feitos para serem cantados em barricadas - como se fosse possível fechar com barricadas as largas vias expressas de Brasília. Geração Coca-cola seria um dos grandes sucessos do primeiro LP da Legião Urbana, posto nas lojas nos primeiros dias de janeiro de $1985 .{ }^{134}$

Em 1984, quando a Legião Urbana foi fazer alguns shows no Rio de Janeiro e São Paulo, a gravadora EMI Odeon logo se interessou pelos rapazes. Mas Renato recusou, por conta da estratégia da empresa e transformá-los numa banda pop-punk.

Seu LP só foi lançado no ano posterior, às vésperas do Rock in Rio, o que fez com que não ganhasse muita repercussão, pois concorriam com o maior festival de rock da história do país. Apesar disso, algum tempo depois, suas músicas começaram a fazer sucesso. Entre elas, citamos Geração Coca-Cola, Ainda é cedo, Por Enquanto, Soldados e Petróleo do Futuro. O teor era, de fato, sociopolítico, com algumas exceções. A Legião Urbana expressava em suas canções o que acontecia no Brasil. Um momento de reestruturação política, mas que não era visto com bons olhos pela população, que se deparava com altos índices de inflação e desemprego. A juventude se identificava com a banda através da desesperança em relação as mudança que poderiam ser empreendidas por ela mesma ou, simplesmente, pelo discurso sobre as drogas.

Apesar do sucesso conquistado com seu primeiro álbum (com teor de protesto), o LP "Dois" abordou temas mais românticos (apenas a algumas faixas, como Índios, ainda tinham resquícios sócio-políticos). Mas ao falar de amor, Renato Russo foi ainda mais competente do que ao falar de política. Não teve jeito, o disco foi novamente um sucesso!

A Legião Urbana foi uma das poucas bandas nacionais do período que tentava, a todo custo, uma emancipação com relação à indústria cultural. A fórmula da recriação comercial do protesto, utilizada por outros vários grupos, não

${ }^{134}$ Ibdem, p. 44. 
foi seguida por Renato. Andou pelos caminhos do lirismo romântico, mesclou sons de rock com músicas de períodos importantes da história musical e manteve-se, mesmo assim, no topo das paradas de sucesso.

Apesar de todo o mérito da banda, o fator industrial da canção não passa desapercebido. A Legião soube usar dos meios de comunicação para atingir os jovens. Sua mudança para o eixo Rio-São Paulo foi primordial para seu crescimento.

A música entra em um espaço marcado da indústria cultural - o lazer. Seu elemento básico, o entretenimento, é o local de mercantilização do ócio. Lugar onde, segundo os Frankfurtianos, seria mais fácil a participação dessa indústria cultural. Mas a música também é, além de elemento de fruição, produto para a reflexão. Dentro de sua canção, o artista pode imprimir toda sua insatisfação com a sociedade. Claro que as música que pressupõem extrema compreensão são deixadas de lado do Mercado, pois ele prima pela massificação e a massa não teria condições de compreensão se tais conteúdos fossem muito difíceis de compreender. Mas o rock dos anos 1980 trouxe uma união entre um ritmo eletrizante, marcado pela rebeldia juvenil e letras elaboradas de grande erudição.

A sua permanência como produto cultural se deve a aceitação do público de um protesto comercializado dos grupos de BRock. Dentro de uma perspectiva mercadológica, a inclusão de letras de elevada erudição é completamente aceitável, ou não, se isso trouxer lucros para a indústria fonográfica.

A mídia encontrou no grupo uma referência para o chamado "rock politizado" e esperava sempre que seus discos lançados trouxessem novidades que agradassem o público jovem.

A Legião teve a sorte (e competência) de atingir esse padrão - de excelência, juntamente com outras bandas como o Barão Vermelho, deixando para os outros grupos musicais a responsabilidade de inovar assim como esses primeiros fizeram. 


\subsubsection{Rock na veia - a consolidação do BRock}

A atitude dos pioneiros do BRock influenciou a criação de novas bandas. Um dos grupos mais famosos da década de 1980 foi o Barão Vermelho. Começou como a maioria dos conjuntos da época: um grupo de jovens tocando guitarras na garagem de casa.

Os músicos foram influenciados pelos Rolling Stones e o Led Zeppelin. Frejat, Maurício, Guto e André formaram a banda, completada depois por Agenor Araújo, o Cazuza.

O primeiro LP foi lançado em 1982 e tinha como carro-chefe "Todo amor que houver nessa vida". O sucesso não veio. O disco não era nem comercial, nem MPB. Mas acabou aproximando o rock da música mais intelectualizada. Quando Caetano Veloso cantou "Todo amor que houver nessa vida" e elogiou Cazuza, o Barão começou a ganhar mais o respeito da mídia e do público. O artista baiano foi acompanhado por Ney Matogrosso que interpretou "Pro dia nascer feliz". A partir daí, a banda estourou.

Bete Balanço, trilha musical de um filme homônimo de 1984, consolidou a carreira de Cazuza a Cia. O sucesso da banda, e de outras que cresciam no cenário nacional, proporcionou o Festival Bete Balanço de Rock, que reuniu milhares de jovens na Praça da Apoteose no Rio de Janeiro.

O impacto causado pelo show, no que tange ao número de jovens presentes, fez com que a indústria fonográfica pensasse em novas possibilidades de mobilizar a juventude para o consumo do rock.

O resultado foi a realização do maior evento de rock no país, o Rock in Rio. Mesclando bandas internacionais com os grupos nacionais mais famosos, o evento se tornou um verdadeiro sucesso. Em sua primeira edição, em janeiro de 1985, a festa contou com Scorpions, AC/DC, Kid Abelha, Eduardo Dusek, Gilberto Gil, Barão Vermelho, Blitz, Nina Hagen, B-52's e Yes. 
Como ocorreu com muitas bandas de rock, o sucesso acabou desgastando a relação entre os músicos, o que ocasionou a saída do vocalista, Cazuza, algum tempo após o Rock in Rio.

Enquanto o Barão Vermelho continuava com uma "cara" mais rock'n'roll, Cazuza, em sua carreira solo, enveredou por mais caminhos mais próximos da MPB, com letras mais elaboradas, agradando tanto o público roqueiro como os mais intelectualizados.

O lançamento de seu primeiro disco trouxe sucessos como "Exagerado" e "Codinome Beija-flor". Com a descoberta da AIDS, Cazuza se tornou mais contundente. Influenciado pela Legião Urbana, as músicas de seu segundo LP traziam uma reflexão bem mais aprimorada e falavam tanto da situação política do país, como de um existencialismo em meio a esse contexto, além da situação que passava diante de uma doença sem cura.

Vivíamos no Brasil uma desilusão com relação às mudanças do país e uma juventude que não tinha uma posição política tão forte quanto a das décadas anteriores.

\begin{abstract}
A geração dos anos 80 viveu, no Brasil, a chamada década perdida (com inflação e retrocesso econômico) e, em todo o mundo, a falta de vontade política da juventude era atribuída "à morte das utopias e ao fim das ideologias". No Brasil, como altos e baixos: euforia e crises de depressão. ${ }^{135}$
\end{abstract}

As Diretas Já, a morte do presidente Tancredo Neves e os sucessivos planos econômicos que não davam certo fizeram com que a juventude se sentisse perdida.

O país vivia uma época de degradação moral, por conta da corrupção política. Esse descontentamento juvenil se encontra na letra de uma das músicas mais importantes da década de 1980: Ideologia, de Cazuza e Frejat.

${ }^{135}$ CARMO, 2001, p. 154. 


\author{
Ideologia \\ Frejat/Cazuza \\ Meu partido \\ É um coração partido
}

$E$ as ilusões estão todas perdidas

Os meus sonhos foram todos vendidos

Tão barato que eu nem acredito

Eu nem acredito

Que aquele garoto que ia mudar o mundo

Freqüenta agora as festas do "Grand Monde"

Meus heróis morreram de overdose

Meus inimigos estão no poder

Ideologia

Eu quero uma pra viver

O meu prazer

Agora é risco de vida

Meu sex and drugs não tem nenhum rock' $n$ 'roll

Eu vou pagar a conta do analista

Pra nunca mais ter que saber quem eu sou

Pois aquele garoto que ia mudar o mundo

Agora assiste a tudo em cima do muro

Meus heróis morreram de overdose

Meus inimigos estão no poder

Ideologia

Eu quero uma pra viver

Ideologia

Pra viver

Cazuza acreditava que sua geração era desunida. Que a união fez com que os jovens da década de 1960 fizessem história. A droga, para ele, era o único elo entre jovens sem ideologia.

Geração sem ideologia, compactada entre os anos 60 e os dias de hoje. Eu fui criado em plena ditadura, quando não se podia dizer isso ou aquilo, em que tudo era proibido. Uma geração muito desunida. Nos anos 60 , as pessoas se uniam pela ideologia. "Eu sou da esquerda? Então a gente é amigo. A minha geração se uniu pela droga: ele é careta ele é doidão. Droga não é ideologia, é uma opção pessoal. ${ }^{136}$

Outra canção desse mesmo disco ficou conhecida como o "hino oficioso de um país sem ética”: Brasil. Essa música representava toda a insatisfação do brasileiro com relação ao seu país. Ele pedia: "Brasil, mostra a tua cara". E

${ }^{136}$ Cazuza por Lucinha Araújo, Cazuza, só as mães são felizes. (Rio de Janeiro: Globo, 1977), p. 373. Apud CARMO, 2001, p. 155. 
mesmo sabendo que o país estava imerso na corrupção e no marasmo, ainda declarava seu amor ao dizer: "grande pátria desimportante/ Em nenhum instante/ Eu vou te trair".

Já desenganado pelos médicos, Cazuza interpreta "Vida Loca Vida" e escreve outro grande clássico do rock nacional, "O tempo não pára”. Denunciava o preconceito de um país que não tinha a moral para tal: "te chamam de ladrão, de bicha, maconheiro/ Transformam o país inteiro num puteiro/ Pois assim se ganha mais dinheiro.

De fato, Cazuza foi o maior profeta do rock nacional desse período. Mas não foi o único. Outras bandas como os Titãs também enveredaram pela crítica social.

O grupo formado por Marcelo Frommer, Tony Belloto, Branco Melo, Nando Reis, Paulo Miklos, Arnaldo Antunes, Ciro Pessoa e Sérgio Brito foi uma banda que marcou a década de 1980 com músicas de letra elaborada. O octeto criticava principalmente a mídia e a indústria cultural. Na letra de "Televisão" deixam bem claro sua opinião: "A televisão me deixou burro, muito burro demais/ agora todas as coisas que eu penso me parecem iguais".

Enquanto isso, em São Paulo, o Ultraje a Rigor enveredava pelo protesto, através de letras engraçadas e uma batida alucinante. A banda, "traduzindo o pensamento da Elite, (...) maltratando a gramática de forma proposital e irreverente, concluiu que a gente 'somos inútil'. 137

Foi um momento de efervescência cultural, marcado, principalmente, pelo rock. Outras bandas também foram importantes, como o Ira!, com sua música que agradava a juventude das grandes cidades; e o RPM, com seu ritmo frenético, bem parecido com o dos Beatles.

O cenário do BRock também teve uma banda punk, o Plebe Rude. Os garotos de Brasília participavam da "Turma da Colina", juntamente com a Legião

${ }^{137}$ CARMO, 2001, p. 150. 
Urbana. Dapieve (1995) acreditava que, por seu caráter mais popular, o grupo pertenceria ao movimento de rock da década de 1980.

De fato, a crítica do grupo à sociedade - muito contundente, por sinal -, era acompanhada por uma batida mais "agradável". Mas mantinham o elemento crítico do movimento.

\section{Até quando esperar?}

Philippe Seavra, André X e Gutje

Não é nossa culpa Nascemos já com uma benção

Mais isso não é desculpa

Pela má distribuição

Com tanta riqueza por aí Onde é que está, cadê sua fração?

Até quando esperar?

E cadê a esmola?

Que nós damos sem perceber

Que aquele abençoado

Poderia ter sido você

Até quando esperar?

A plebe ajoelhar esperando a ajuda de Deus

Posso? Viajar teu carro, te pedir trocados, engraxar seu sapato?

Até quando esperar?

A plebe ajoelhar esperando a ajuda do divino Deus

Enquanto isso, no Rio Grande do Sul, o rock nacional também impulsionava a criação de novos grupos. Dessa safra, podemos citar os Engenheiros do Hawaí, que propunham uma crítica à inércia dos jovens daquela década. Em sua música Terra de Gigantes, cantavam a incapacidade dos jovens de, nesse momento, refletirem sobre as mudanças e, principalmente, de se organizarem em torno delas.

Terra de Gigantes

(H. Gessinger)

Hey, mãe

Eu tenho uma guitarra elétrica

Durante muito tempo isso foi tudo

Que eu queria ter

Mas, hey mãe

Alguma coisa ficou pra trás 


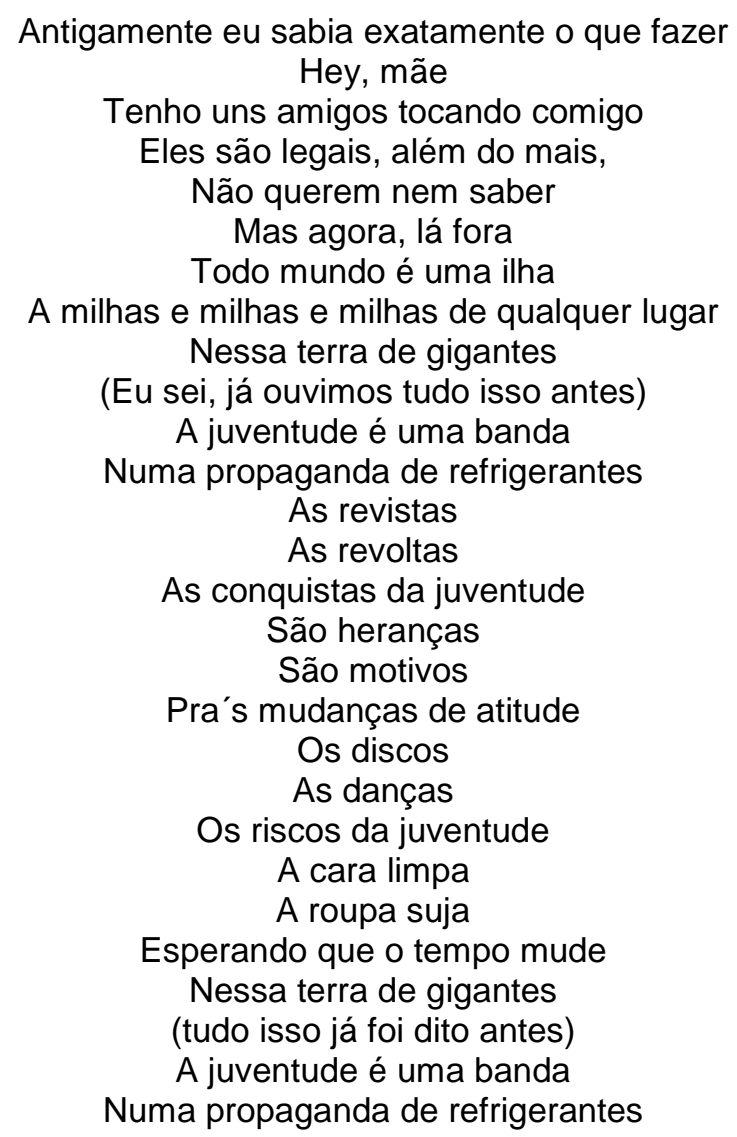

Os Engenheiros do Hawaí foram a prova da tentativa de politização da música, pura e simplesmente, para atrair o mercado fonográfico. A banda, que sempre foi alvo de duras críticas, em suas "baladinhas" de "letras prontas", ajudou, juntamente com outros grupos, a "esvaziar" o sentimento político do BRock. Por isso, ao analisarmos o caráter mercadológico de todo o movimento, temos que destacar o papel distinto das bandas. Enquanto umas buscavam somente a incorporação do ritmo, outras primavam pela crítica social. Mas, algumas dessas, não tinham a criatividade suficiente para fazê-lo, banalizando o protesto.

No geral, os grupos de rock dos anos 1980 se constituíram com base em um ritmo aceito pela juventude e vendável pela Indústria Cultural. Apesar da influência punk, nenhum grupo acompanhou "literalmente" os ditames do movimento. Todos preferiram seguir pelo "new wave", que era um pouco mais comportado, e que já tinha sido balizado como produto de consumo pela juventude brasileira e mundial. 
Os grupos traduziam o sentimento de um país, mas também buscavam sanar as necessidades de uma juventude que se sentia "medíocre" com relação aos jovens dos anos 1960 e 1970. O fato de não se ter o que combater e o vazio trazido pela redemocratização viraram produto cultural nas letras do BRock. Mas deixo claro, que isso não impediu que muitas músicas e letras do período fossem de extrema qualidade.

Do outro lado - o da indústria cultural -, se observava no Brasil uma conjunção cada vez maior entre rádios, discos e televisão, principalmente a partir da crise de vendagens no início dos anos $1980^{138}$.

A necessidade da criação de novos ídolos era uma premissa para a sobrevivência da indústria musical (especialmente da indústria fonográfica) no Brasil. Enquanto grandes bandas de rock cresciam no cenário internacional, o nosso país ficava estagnado com relação a essas novas tendências, escutando somente MPB.

\begin{abstract}
O mercado de produtos fonográficos que até pouco tempo antes era um dos melhores negócios do Brasil, entrou os anos 80 em meio a uma incógnita. Receosa, a indústria fonográfica, bem como todos os outros setores da indústria musical, não tiveram que esperar muito para que surgisse a solução que capacitasse a retomada do seu crescimento. A solução acabou sendo o rock nacional, que nada mais fez do que atingir $e$ mobilizar aquela juventude e adolescência enraizada da cultura nacionalista e das preocupações populistas características da juventude de classe média das décadas anteriores. ${ }^{139}$
\end{abstract}

Foi construída toda uma estrutura de entretenimento para abrigar a juventude sedenta pelo rock nacional. Nesse contexto que nasce o "Circo Voador". Criado no ano de 1982, localizado na praia do Arpoador no Rio de Janeiro, essa casa promoveu o primeiro "Verão do Rock".

${ }^{138}$ GROPPO, L. A. O Rock e a formação do mercado de consumo juvenil - a participação da música pop-rock na transformação da juventude em mercado consumidor de produtos culturais, destacando o caso do Brasil e os anos 80. Dissertação (Mestrado). Universidade Estadual de Campinas, 1996, p. 204.

${ }^{139}$ Idem. 
Lá existiam das mais variadas atrações artísticas, juntamente com a apresentação de bandas famosas ou do circuito underground do BRock. Nesse mesmo momento, a Rádio Fluminense FM inova, trazendo uma programação baseada no new wave carioca. Influenciando outras rádios a seguirem o mesmo caminho. O Rock in Rio também é um exemplo do aumento dessa infra-estrutura da indústria.

No seu início, o rock acabou se tornando um ritmo descompromissado, que tinha relação direta com o entretenimento dos jovens. O sucesso do Circo Voador inspirou a formação de outros festivais, sempre nas praias, de preferências nos meses de dezembro e janeiro - época do verão.

Esse modelo se espalhou para todo o país. As grandes corporações perceberam esse filão. A Coca-Cola, por exemplo, nesse período, colocou no ar uma publicidade que se passava em uma praia do Rio, com vários jovens, ao som do rock nacional.

Foram criadas também danceterias no Rio e em São Paulo. Diferente do modelo do Pub inglês, ou das grandes casas americanas, as danceterias brasileiras eram casas de show ou boates que aumentaram suas pistas de dança e tocavam os hits do rock nacional.

O modelo carioca se esgotou, mas a música politizada tomou seu lugar. O RPM, por exemplo, foi minuciosamente preparado para se tornar um sucesso. Além de sua semelhança com as bandas internacionais, o show dos rapazes era cheiro de efeitos visuais, como muitas luzes, fumaça de gelo seco e uma certa teatralidade.

Os outros grupos musicais como Paralamas, Legião e Barão proporcionaram alta vendagem de discos e eram os "queridinhos" dos jovens da época.

A decadência do movimento veio com a "banalização" do protesto iniciada por grupos como os Engenheiros do Hawaí. O modelo tinha se esgotado. A partir desse momento, o cenário pop é o que começa a vigorar no nosso país. 
Seja nos seus primeiros momentos ou na sua consolidação a partir de meados dos anos 1980, o que pudemos verificar foi a consolidação do movimento pela indústria cultural o que propiciou, juntamente com outros fatores, uma cobertura constante da mídia brasileira. 


\section{CAPÍTULO IV \\ CULTURA DA JUVENTUDE: A ABORDAGEM DA VEJA E DA FOLHA DE SÃO PAULO}

\subsection{Mídia impressa, juventude e Indústria Cultural}

A indústria cultural deve ser pensada através de sistemas harmônicos que se reúnem para a comercialização e mercantilização da produção cultural. Não que eu esteja com isso, falando de um sistema maquiavélico ou uma conspiração para a manipulação do público, mas sim, que essa organização faz com que as estratégias de marketing e sedução de novos consumidores se tornem mais fáceis de serem empreendidas.

A produção de um filme voltado para a juventude, por exemplo, passa pela filmagem da película, a distribuição, publicidade, criação de games, camisetas, bottons, sites na internet, notas na imprensa, pauta para os grandes meios de comunicação, além de outras medidas.

Por vezes as repercussões na mídia não são diretamente intentadas pelos grandes empresários da indústria cultural. Elas são conseqüência de uma sedimentação do consumo. A mídia escrita - nosso objeto nesse capítulo - vai ao encontro dos anseios da sociedade por notícias, pois ela acompanha o que já está sendo discutido na esfera pública.

Realmente, existe um diálogo entre a esfera pública e os meios de comunicação. No caso de aprovação, por parte do público de um produto cultural, ele se torna imediatamente pauta da imprensa. Mas essa também acaba por colocar novos elementos, informações e fontes. Esse contínuo fluxo das informações faz com que a mídia perceba na sociedade o que deve ou não se publicado.

Claro que esse modelo só pode se pensado dentro de um momento democrático, onde as informações podem circular de maneira "livre". Alerto para 
essa liberdade, por conta da linha editorial dos diversos meios que podem ser comprometidos com grupos empresariais, além de outros interesses que não os da população em geral. O fato é que, quando de um Regime Autoritário, a informação se torna ainda mais prejudicada, devido ao papel censor do Estado, ou simplesmente pela possibilidade ir contra aos ditames de um Governo autocrático.

No que tange a cultura da Juventude, a mídia corrobora com aquilo que é consolidado pelo mercado cultural. Apesar de fazer algumas críticas ao próprio sistema - que mercantiliza a obra dos artistas -, a imprensa, mesmo imbuída de seu papel social - o de informar - é, em primeiro lugar, uma empresa, por isso mesmo, visa a lucratividade.

Desde a consolidação do rock na década de 1950 e sua vinda para o Brasil algum tempo depois, o jovem vem sido um elemento de destaque dentro das páginas dos jornais e revistas nacionais.

Acontece que muitas das manifestações de juventude no nosso país, começaram longe dos holofotes da indústria fonográfica. Aqueles que conseguiram se consolidar e ganhar um público massivo acabaram sendo englobados pelas gravadoras e a indústria cultural. Por isso mesmo, esses movimentos, antes de ganharam o respaldo do mercado e da opinião pública jovem, não ganhavam o respeito necessário dos meios de comunicação.

Algumas manifestações ditas fugazes em seu início, após a entrada no mercado de consumo jovem, são tratadas como informação preciosa pela mídia. A imprensa leva em consideração vários aspectos para balizar um movimento juvenil, entre eles, a concordância da sociedade; sua adaptação nos padrões sociais; sua importância para o mercado fonográfico; suas inovações ou criatividade, que o encaixam ou não como obra da alta cultura ou do "melhor gosto"; a linha editorial do meio; a aprovação ou reprovação de suas atitudes quando em períodos não-democráticos; e sua harmonização com os outros sistemas da indústria cultural. 
Pode-se perceber, assim, que a abordagem sobre determinados movimentos da juventude - ou bandas e grupos musicais - irá mudar com o tempo. Se em alguns momentos a imprensa os julga como "modismos", em outros os consolida como movimentos consolidados. Se faz reportagens sobre suas inovações estéticas, algum tempo depois pode destacar seu esvaziamento para se tornar mero produto de consumo.

Nessa pesquisa, ao apresentar tais exemplos, uma análise será feita sobre seu contexto. O momento social do país, a consolidação do grupo no mercado e outros fatores importantes. $O$ trabalho não se detém a estudar a imprensa em sua linha editorial ou verificar o seu discurso. Prende-se a entender como funciona a indústria cultural (e a mídia, como sistema dessa indústria) na sua relação com a juventude e com o contexto social nas décadas de 1970 e 1980. Deixo claro, que os fatores apresentados podem não ser os únicos a influenciar a abordagem da imprensa sobre tais movimentos culturais, mas, dentro da perspectiva da indústria cultural, configuram-se como importantes.

Como já apresentamos na Metodologia ${ }^{140}$, a escolha de meios escritos de imprensa se fez pela facilidade de busca dos dados e informações. A Revista Veja e o jornal Folha de São Paulo foram escolhidos por sua importância - como dois dos maiores meios de comunicação do país - além de aumentar mais a diversidade de fontes - pois são um semanário e um diário - e pelo fato de existirem no período escolhido (a Revista Veja, um tempo depois, só no ano de 1968).

A coleta de dados da Revista Veja foi feita através de todos os seus exemplares desde o ano de 1968 até o final da década de 1980. As fontes conseguidas junto à Folha foram feitas através de palavras chave (juventude, rock, punk, disco-music, pop, rock brasileiro, tropicalismo) no seu banco de dados dentro do período apontado.

${ }^{140} \mathrm{O}$ item foi apresentado na INTRODUÇÃO. 
Foram escolhidas as reportagens mais relevantes para a análise, para que ilustrassem o que foi debatido no capítulo anterior ${ }^{141}$. O contexto das reportagens foi refletido através da analise histórica, das teorias relativas ao assunto e através das fontes secundárias (autores que escreveram sobre o tema).

A Folha de São Paulo foi criada em 1921. Nesse momento tinha o nome de Folha da Noite. Na década de 1960 foi comprada por Octávio Frias e Carlos Caldeira Filho, quando seu nome foi trocado pelo atual. No final da década de 1960, a Folha não tinha a juventude como uma de suas pautas mais freqüentes, a não ser sua relação conflituosa com o Regime Militar. Mas na década de 1970, o jornal criou um caderno especial só para falar da temática jovem e sua relação com a música.

A Revista Veja, que se chamava Veja e Leia, no seu começo, foi criada em 1968. Pertence ao grupo Abril e é, hoje, a maior revista semanal do país. A publicação sempre manteve em seus cadernos, um espaço para a Música. E, neste espaço, a juventude tinha lugar privilegiado.

\subsection{Um olhar através da Folha e da Veja}

A tropicália foi um movimento muito forte na cultura da juventude brasileira. Suas inovações estéticas marcaram a música nacional. E suas letras vieram ao encontro do momento dos jovens, que protestavam contra o Regime Militar.

Quando lançada no Festival da Música Brasileira, ainda não configurava como movimento, mas foi lembrado pelos meios de comunicação. Algumas notas foram colocadas na Folha de São Paulo. No final do ano, em sua retrospectiva, esse veículo, falou sobre o tropicalismo na reportagem "ESSE ANO NA MÚSICA POPULAR BRASILEIRA", de 11 de dezembro de 1967.

\footnotetext{
${ }^{141}$ Cultura da Juventude nas décadas de 1970 e 1980.
} 
Deu destaque às canções Alegria, alegria de Caetano Veloso e Domingo no Parque de Gilberto Gil. Discorreu sobre o tropicalismo como um movimento, mas sem dar a devida importância. O destaque do jornal ficou para Roberto Carlos e a Jovem Guarda que continuavam nas paradas de sucesso das rádios nacionais.

A falta de entusiasmo da Folha pode ter sido motivada, além de outros fatores, pelo fato de Caetano não ter sido ainda, naquele momento, um produto comercial consolidado. Seu LP individual de estréia só seria lançado em janeiro do ano seguinte.

O ano de 1968 veio consolidar a carreira dos tropicalistas, que eram bem recebidos tanto pela crítica quanto pelo público. Apesar disso, ainda aos olhos da imprensa, o tropicalismo, se já reconhecido, começou a ser visto, pelo menos nas reportagens da Folha de São Paulo, como movimento mercadológico que se cansaria rapidamente e precisava do apoio dos meios de comunicação para continuar nas "graças" do público.

Na edição n. 2 de 18 de setembro de 1968, a reportagem da Veja e Leia intitulada "OS MUSICAIS AMEAÇADOS", fala do público jovem, cansado das mesmas músicas e pedindo renovação.

Desse modo, era essencial ter criatividade, mas se essa não fosse suficiente, era importante se mostrar para o público. A televisão era um ótimo meio de ser lembrado sempre. Segundo a reportagem, nenhum artista pode viver sem TV. Todos os artistas seguiam esse caminho,

Pelas mesmas razões (acabou de lançar o LP Tropicália), Caetano Veloso prepara-se para voltar à TV. Faz tanta questão, que ameaçou brigar com a Rhodia e TV Globo, com as quais tem contrato, porque o programa não foi lançado imediatamente. Caetano Veloso volta com Gilberto Gil e Eliana Ptiman, no que eles mesmos chamam de "onda Tropicalista. ${ }^{142}$

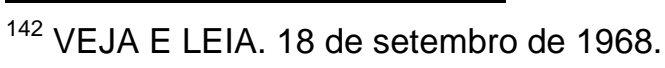


No famoso episódio das vaias para Caetano e Cia, a Veja e Leia tomou partido dos estudantes, ávidos por canções de protesto e não por inovação estéticas.

$\mathrm{Na}$ sua edição n. 3 de 25 de setembro de 1968, estava em destaque a reportagem "UM FESTIVAL DE PROTESTOS - Depois que os compositores partiram para a cenografia, quem começa a protestar é o público".

O grande diferencial dos tropicalistas para Geraldo Vandré era a sua forma de falar dos problemas do país. Dentro da simples crítica ao Regime, existia uma crítica sobre todo o modo como víamos o mundo, sobre a música, sobre o imperialismo cultural, sobre como poderíamos resgatar elementos nacionais e mesclá-los com elementos de fora. É proibido proibir tinha em sua letra forte conteúdo de protesto, mas a forma pela qual foi apresentada não agradou muito a juventude presente, nem os meios de comunicação.

O público aceitou a música, mas não a maneira como ela foi apresentada: Caetano e os Mutantes com estranhas roupas de plástico, um autêntico hippie americana a urrar palavras sem nexo enquanto requebrando, Caetano dizia um verso de Fernando Pessoa e Rogério Duprat, o arranjador, tirava da orquestra sons metálicos e agressivos. ${ }^{143}$

Para corroborar sua abordagem, a revista no final do texto fala também da alta vendagem de discos, os altos índices de lbope dos festivais, fazendo com que apareçam cada vez mais patrocinadores para o evento. Por isso, a necessidade de seus músicos agradarem o público presente.

Apesar desse episódio, era inegável que o movimento tropicalista se consolidava cada vez mais. E a mídia pregava que a juventude só tinha dos caminhos a seguir: ou o dos baianos revolucionários ou o da bossa nova.

A Edição n. 6 de 16 de outubro de 1968 da Veja e Leia trazia a reportagem "COM ELES É BRIGA NA CERTA - Gilberto Gil, Caetano e Os Mutantes revolucionam festivais e propõem num novo caminho para a música brasileira"

${ }^{143}$ Idem, 25 de setembro de 1968. 
falava do Festival da Música Brasileira que começaria em poucos dias e mostrava que os grupos se dividiam entre os tropicalistas e a bossa-nova.

Opinião reforçada em uma edição posterior (edição n. 10 de 13 de novembro de 1968). "EXISTE ALGO DE CONCRETO NOS BAIANOS - nas palavras de suas canções, uma revolução poética iniciada por outra geração". No texto ressaltava-se o fato de os tropicalistas mesclarem elementos da poesia, artes, tendências culturais e elementos nordestinos. "Os tropicalistas querem ser hoje a medula e os ossos da música brasileira".

Nesse período, Divino, Maravilhoso, interpretado por Gal Costa, consegue o 4 lugar no quarto Festival de Música Popular Brasileira e estréia o programa Divino, Maravilhoso na TV Tupi. A Tropicália estava em todos os lugares. Isso foi bom para o crescimento e divulgação do movimento, mas causou, em pouco tempo, um desgaste, dele e das canções de protesto, por conta da comercialização que sofriam.

Tanto que na edição n. 12 de 27 de novembro de 1968, apareceria o texto "ELES DIZEM NÃO, MAS TODO MUNDO APLAUDE - da batucada de mesa ao festival de faixas, os músicos brasileiros têm protestado contra quase tudo. Mas o protesto é belo, vale dinheiro e quem está contra acaba passando para o outro lado". O argumento é de que a propaganda e a mídia "esvaziaram" o que tinha de conteúdo nas letras de protesto. Claro que esqueceram de citar o papel da revista nesse processo.

\footnotetext{
Inimiga da miséria e da injustiça, a música de protesto tem, também, seus inimigos: o primeiro é a realidade, que resiste aos seus ataques, e o segundo é a publicidade que dissolve o protesto em modelos de roupa e transforma os artistas zangados em personalidades muito bem pagas". Continua: "quem protesta, se faz boa música ou música de agrado popular, geralmente sobe na escala social e passa a produzir um produto que cheira a falta de autenticidade. A propaganda, os programas de televisão, a imprensa e os empresários trabalham para nivelar o gosto do público. E a música de protesto começa a ser atacada por uma última razão: seus autores estariam, em última instância, fazendo o jogo das pessoas ou coisas contra as quais protestam. ${ }^{144}$
}

\footnotetext{
${ }^{144}$ Idem, 27 de novembro de 1968.
} 
Poucos dias depois, entra em vigor o Ato Institucional n. 5. Nem a revista e nem o jornal abordaram temáticas musicais contrárias ao regime. Depois do Al-5, Caetano e Gil foram presos e exilados, assim como outros músicos e artistas que poderiam ser considerados "subversivos".

O que vemos é um "silêncio" sobre o tropicalismo e as canções de protesto. O que acontecia nos rincões das músicas ditas "subversivas" não ganhava destaque nos meios de comunicação.

Nesse período, a indústria cultural operava de forma diferenciada, dentro dos limites impostos pelo governo, seja de forma objetiva ou subjetiva. Nenhum produtor musical queria investir em algum artista que pudesse entrar em confronto com o Regime Autocrático e mesmo as empresas do setor, não gostariam de se arriscar.

Os meios de comunicação já eram vigiados de perto e, nem que quisessem, poderiam colocar notícias que fossem contrários ao Governo brasileiro. O que encontramos, nesse período, - quando encontramos - são pequenas referências aos artistas do tropicalismo, claro que, retirados do seu contexto inicial - de música de protesto.

A mídia não tinha a liberdade para tratar dos assuntos que interessavam a população em geral. Alguns jornais e revistas não aceitaram as determinações do Governo e acabaram sendo fechados e, alguns de seus jornalistas e repórteres, presos. Os que não desafiavam o Regime tinham que "dançar conforme a música". Outros decidiram ir para o lado do próprio governo, servindo, efetivamente, como aparelhos ideológicos do Estado. Aos que continuaram a exercer suas atividades, o que imperava era o "bom senso" com relação aos limites impostos.

No ano de 1970, a Folha de São Paulo mostra uma reportagem do espetáculo "Hair", que poderia até ser entendido como contrário às normas da sociedade brasileira, mas que já tinha sido balizado como produto de consumo, apesar da nudez apresentada na adaptação brasileira do espetáculo, feita por Ademar Guerra (Figura 1). Enquanto isso, os hippies, inspiração para o 
espetáculo americano, eram presos por "vadiagem" em uma praça de São Paulo (Figura 2).

Figura 1 - Reportagem: O êxito e a volta de Hair.

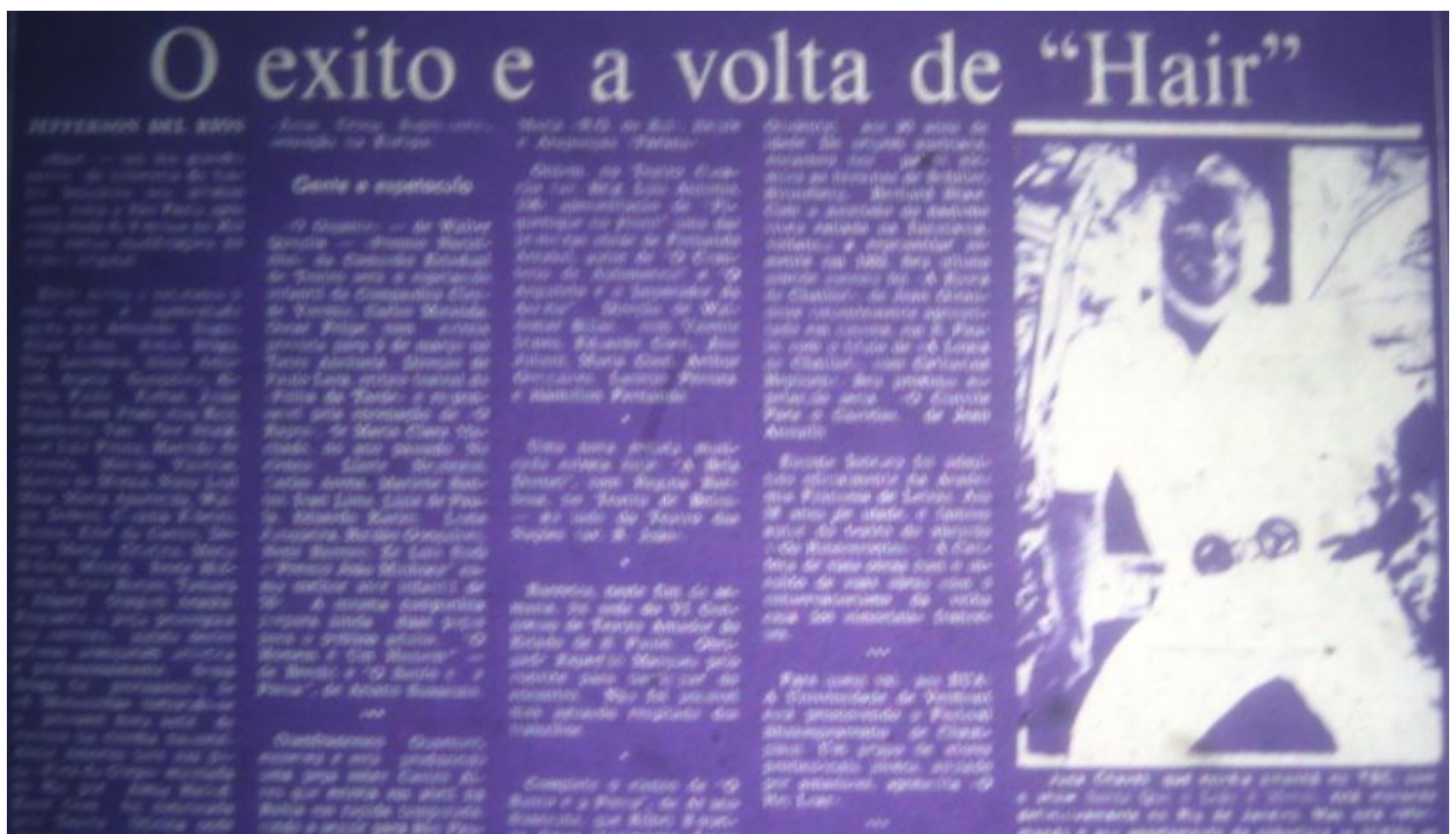

Fonte: Folha de São Paulo, janeiro de 1970.

Figura 2 - Reportagem: Polícia prende mais de cem hippies na praça

\section{Policia prende mais de cem "hippies" na praça}

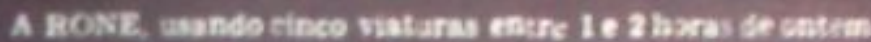

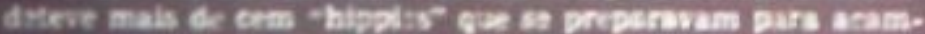

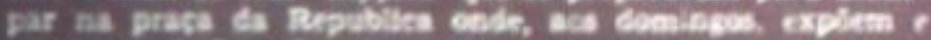
Eradea trabalhes de arteragato

Condulas as 1 o DP. foram stantidos a triarem

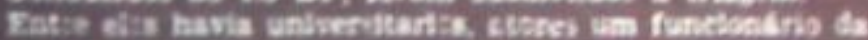

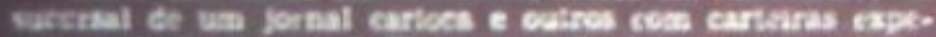

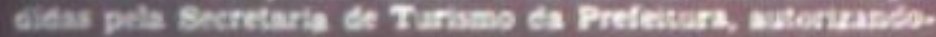
en a cingar an prest.

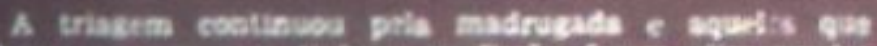

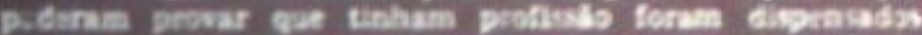

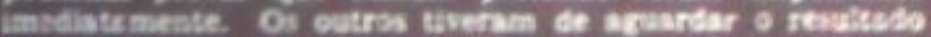

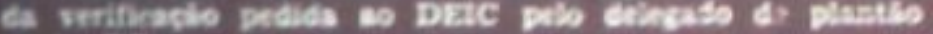
no 10 bP

Fonte: Folha de São Paulo, 12 de janeiro de 1970. 
No mês de março, na Veja e Leia, aparece uma reportagem sobre a música de vanguarda, com sutis referências ao tropicalismo, ressaltando, somente, seu caráter de movimento estético na música (Figura 3). Comenta-se do vazio deixado por Caetano Veloso e Gilberto Gil e o aparecimento de alguns grupos inovadores, mas que não conseguiram alcançar ainda o sucesso de seus antecessores. Seja pela competência, seja pela impossibilidade de um movimento cultural de juventude existir sem uma crítica social.

Nessa matéria, o editor de música, Tárik de Souza, comandou uma equipe de repórteres em busca de vozes e das intenções dessa nova dianteira musical. O repórter deixa claro, portanto, que necessariamente a vanguarda não é relacionada ao ativismo político, a ela, está intrinsecamente ligado o fato de se fazer o novo. Fala de conjuntos como os Novos Baianos. Ressalta suas qualidades, mas aponta que os mesmo fazem um tropicalismo amador querendo dar continuidade ao trabalho de Caetano e Gil, sem tem o mesmo talento. Destaca ainda bandas, como O Bando, Hermes e Laís, Equipe Mercado e Laboratório de Sons Estranhos. Todos esses mais voltados para o mercado, tendo suas canções diretamente feitas para as rádios, como explica Laís (Hermes e Laís). O Bando rebaixou o palco do Teatro Galpão em São Paulo para ficar ao nível da platéia. Para um de seus integrantes, Memé, "essa é a única maneira de conseguir que o público paulista - meio burro -, despreparado e orgulhoso participe do show" (Veja e Leia, 1ํ de março de 1970).

Enquanto o tropicalismo se mantinha (ou era mantido) esquecido, um de seus participantes, que sempre teve um apelo mais popular, continuava sendo pauta para a mídia: Os Mutantes. Para a indústria cultural, o grupo era fácil de ser vendido. Se existia protesto no seu modo de vestir e de deturpar os valores, esse não era compreendido por todos. Existia, portanto, um sucesso de vendas que, ainda por cima, não seria considerado "subversivo".

Por conta disso, Os Mutantes continuaram a ser pauta na imprensa. Em uma reportagem da Folha de São Paulo, apesar de mostrar a preocupação do Governo com uma reação juvenil em um grande show, o jornal reforçou o aspecto massivo da banda (Figura 4). 
Figura 3 - Depois de Caetano

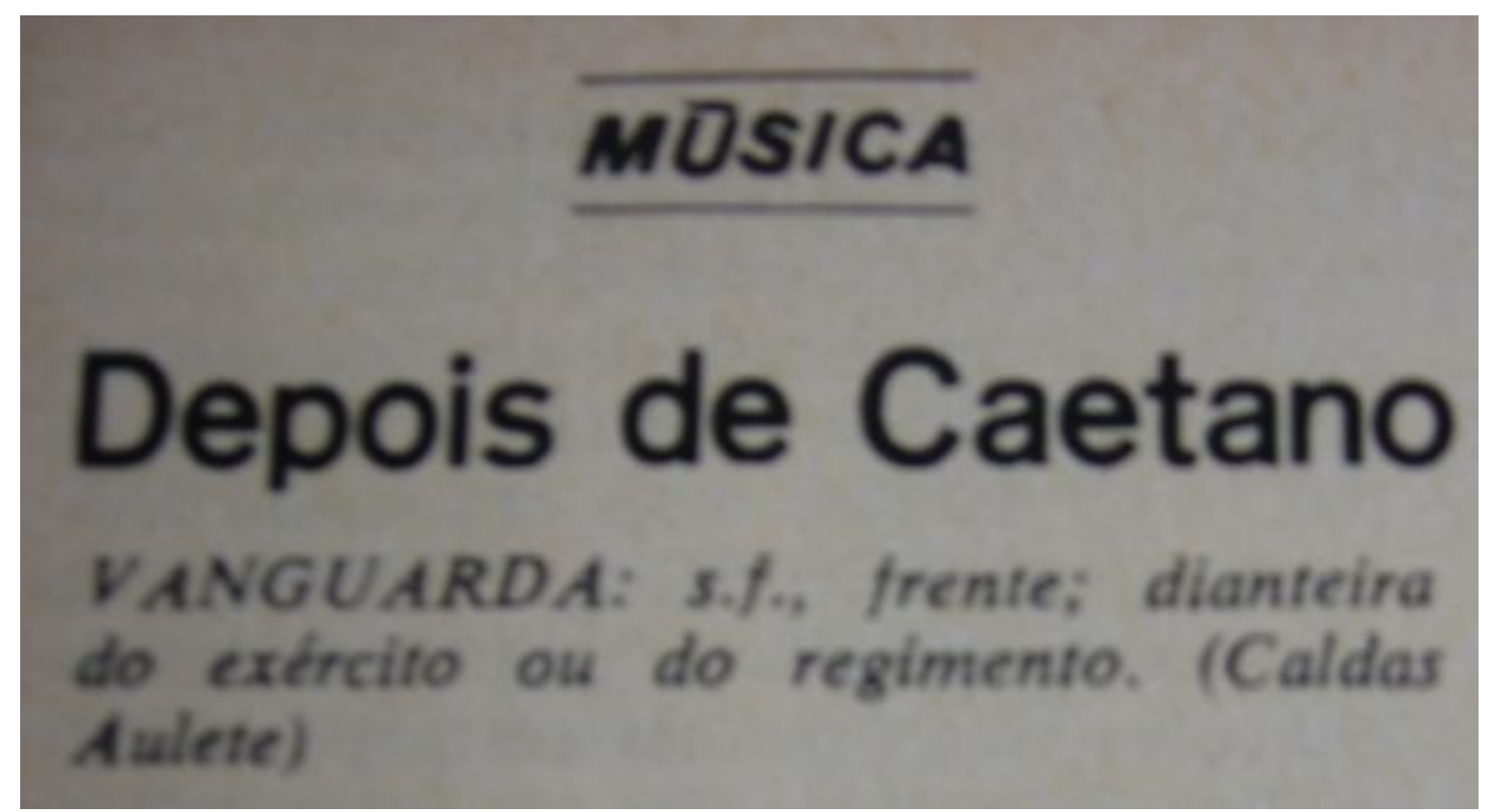

Fonte: Veja e Leia, n. 82 de $1^{\circ}$ de março de 1970.

Figura 4 - Reportagem: A magia da música popular

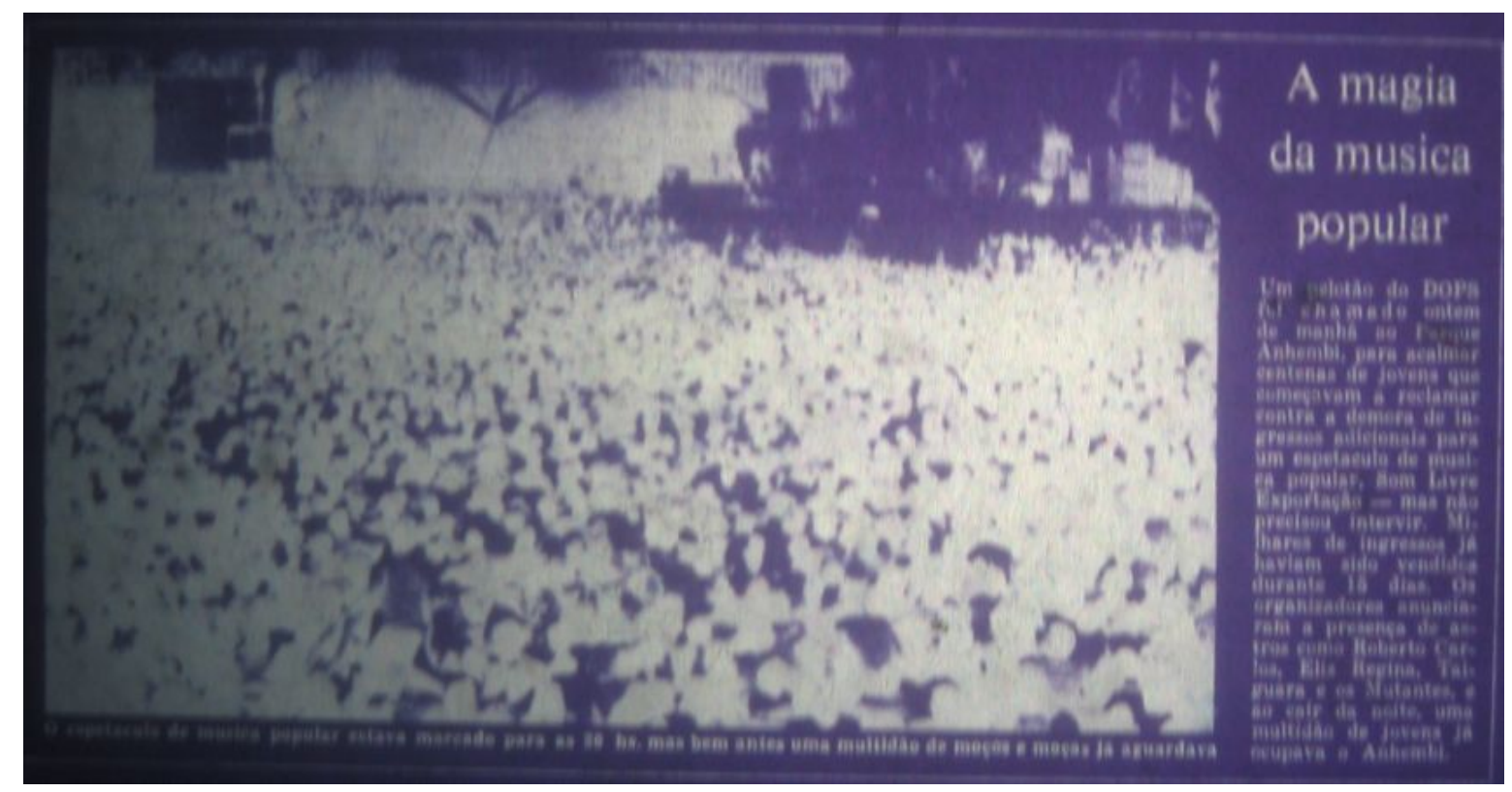

Fonte: Folha de São Paulo, 25 de fevereiro de 1970. 
Se o jornal mostrava o crescimento do rock nacional com Os Mutantes e Raul Seixas, alguns colunistas da Folha demonstravam sua opinião, que era absolutamente de Direita e a favor do Regime. Em sua coluna de 14 de março de 1971, TAVARES DE MIRANDA faz elogias à censura:

\begin{abstract}
Está certo o governo e o Ministro Alfredo Buzaid na intensificação da censura prévia principalmente nas revistas, filmes, TV e espetáculos. Milhões de mães e pais brasileiros não admitem esse afrouxamento moral que anda por aí, principalmente motivado pela difusão do sensualismo, do naturalismo e erotismo, difundidos por toda parte. E esses milhões são que contam, porque constituem o pólo brasileiro autêntico e não essa meia dúzia de falsos intelectuais e "artistas" muitos dos quais assaltamos meios de divulgação mais eficientes. ${ }^{145}$
\end{abstract}

Algumas matérias reforçavam essa visão sobre a juventude atual no Brasil e no mundo. O momento era "perigoso" e o país estava sendo "reorganizado" pela Ditadura militar. Para que essa ideologia fosse balizada, era necessário que todas as instituições sociais estivessem em consonância com o que era apregoado pelo Regime. A Folha dava destaque, inclusive, para as declarações católicas sobre as atitudes juvenis (figura 5).

A Reportagem fala do apelo do Papa aos jovens e como a vida moderna os amoldou. "Desses jovens que vangloriam de ser inovadores, rebeldes, destruidores do que as gerações precedentes construíam e seguros, ao mesmo tempo, de uma transformação social e libertadora da sociedade".

O momento não era bom para a juventude brasileira. Se a crítica midiática não era sobre o movimento juvenil em si, era sobre a música jovem nacional, que estava terminando e dando espaço aos ritmos internacionais. Se não diretamente pela compra dos LP's de ídolos como Bob Dylan, o seria pela "americanização" dos grupos brasileiros.

Na Revista Veja e Leia, edição n. 95 de $1^{\circ}$ de julho de 1970 aparece uma reportagem intitulada "O FIM DO SOM JOVEM NO BRASIL" que destacava a falta de criatividade dos grupos nacionais e a ascensão das músicas internacionais. A

${ }^{145}$ FOLHA DE SÃO PAULO, 14 de março de 1971. 
jovem guarda começa sua crise e a tropicália nem mesmo é citada na reportagem. Há um destaque para o desgaste da imagem dos artistas nacionais.

Figura 5 - Reportagem: Papa Paulo VI fala à juventude

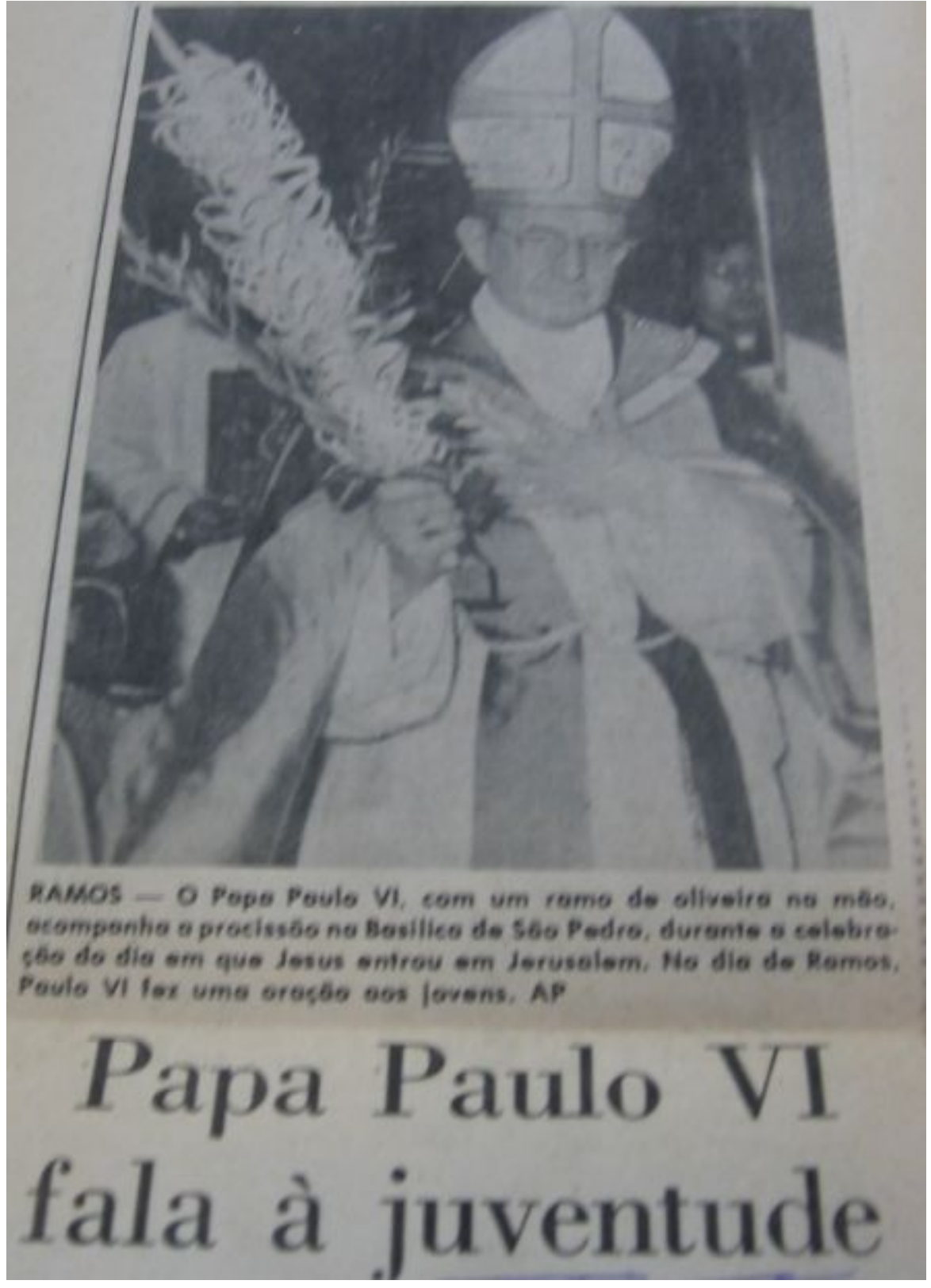

Fonte: Folha de São Paulo, 16 de abril de 1973. 
Na edição de n. 99 de 29 de julho de 1970 da revista, aparece uma matéria intitulada "THE "SOUND OF MUSIC, mostrando a enxurrada de música estrangeira que vem para o Brasil (cerca de $70 \%$ das músicas tocadas nas rádios) e um projeto de lei da Câmara dos Deputados (redigido pelo deputado Auro Melo) que queria reduzir esse percentual a $30 \%$. O valor pago pelas músicas internacionais era muito baixo e se tornou uma mina de ouro para os que investiram em rádios especializadas, como Carlos Imperial.

Nessa mesma edição, a revista mostra uma reportagem sobre "O PODER DA MÚSICA", com o subtítulo "Tradição e Maconha". A pauta era a relação entre a música jovem e a maconha na cidade de Ouro Preto durante um festival de Inverno. Os jovens do evento teriam sido influenciados pelo hippismo americano e seu modo de vida, trazidos, principalmente, pela música internacional.

Por seu caráter mais comercial, Os Mutantes sempre continuaram na mídia, apesar das severas críticas ao seu estilo. Para alguns setores da imprensa, sua música poderia até animar a juventude, mas não tinha nenhuma perspectiva de crescimento no que tange à inovação. Tanto que na edição n. 132, a revista faz severas críticas ao novo LP dos Mutantes.

A irreverência pode parecer o caminha mais fácil a um conjunto formado de jovens de cabelos longos, boas idéias e guitarras elétricas. Mas, certamente, não é a distância mais curta entre um grupo de vanguarda como os Mutantes e seus consumidores, sempre ávidos por surpresas. ${ }^{146}$

Acontece que, no mundo, o rock estava ressurgindo, agora, fora do contexto das canções de protesto, com o heavy metal do Led Zeppelin e as boas canções dos Rolling Stones tomando de assalto o gosto da juventude, inclusive no nosso país.

Esse movimento foi tão forte, que fez os meios escritos reverem suas posições sobre a música internacional, pelo menos, no fato de nossos grupos serem influenciados por ela.

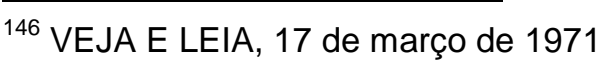


Quando da saída de Rita Lee dos Mutantes, a Folha de São Paulo foi extremamente positiva na reportagem "MUTANTES TRANSFORMADOS". A mudança proporcionada por Arnaldo Baptista tinha dado ao grupo uma identidade que já era balizada pela juventude nacional: o rock de qualidade, sem grandes representantes no Brasil.

Quem foi neste último fim de semana assistir os Mutantes, no Teatro Bandeirantes, teve uma agradável surpresa. Ao invés de música melosamente comerciais, como costumava fazer, proporcionam uma heavy metal, uma mudança de estilo completa. (...). Finalmente, após oito anos de existência, os Mutantes passaram, definitivamente, a ser um grupo de rock, classificado entre os melhores em nosso país e produto para exportação. ${ }^{147}$

Começava-se no Brasil um processo de "industrialização do rock". Acontece que a nossa música jovem ainda se mantinha fiel ou aos preceitos da contracultura - no caso dos Mutantes e Raul Seixas - ou voltada para a bossanova.

As rádios continuavam a tocar as músicas internacionais e os ídolos da juventude brasileira eram cantores normalmente americanos. A possibilidade de ter um ídolo nacional, ao meu ver, era um grande desejo da indústria cultural brasileira. A fabricação dos LP's nacionais traria uma evolução para nossa indústria fonográfica, movimentaria o mercado de shows e grandes eventos de rock, aumentaria o lucro da indústria de instrumentos, principalmente guitarras, seguindo o exemplo do que ocorria nos EUA.

Quando os Mutantes enveredaram por esse caminho, acabaram "puxando" outras bandas que queria adentrar o caminho do rock. A Folha de São Paulo, na sua edição de 21 de outubro de 1974 apontava: "O BRASIL ACABA DE DESCOBRIR UM VELHO PRODUTO: ROCK'N'ROLL". A reportagem era uma das primeiras a ilustrar o novo caderno sobre o rock.

${ }^{147}$ FOLHA DE SÃO PAULO, 9 de outubro de 1974. 
Figura 6 - Reportagem: O Brasil acaba de descobrir um velho produto: o rock'n'roll

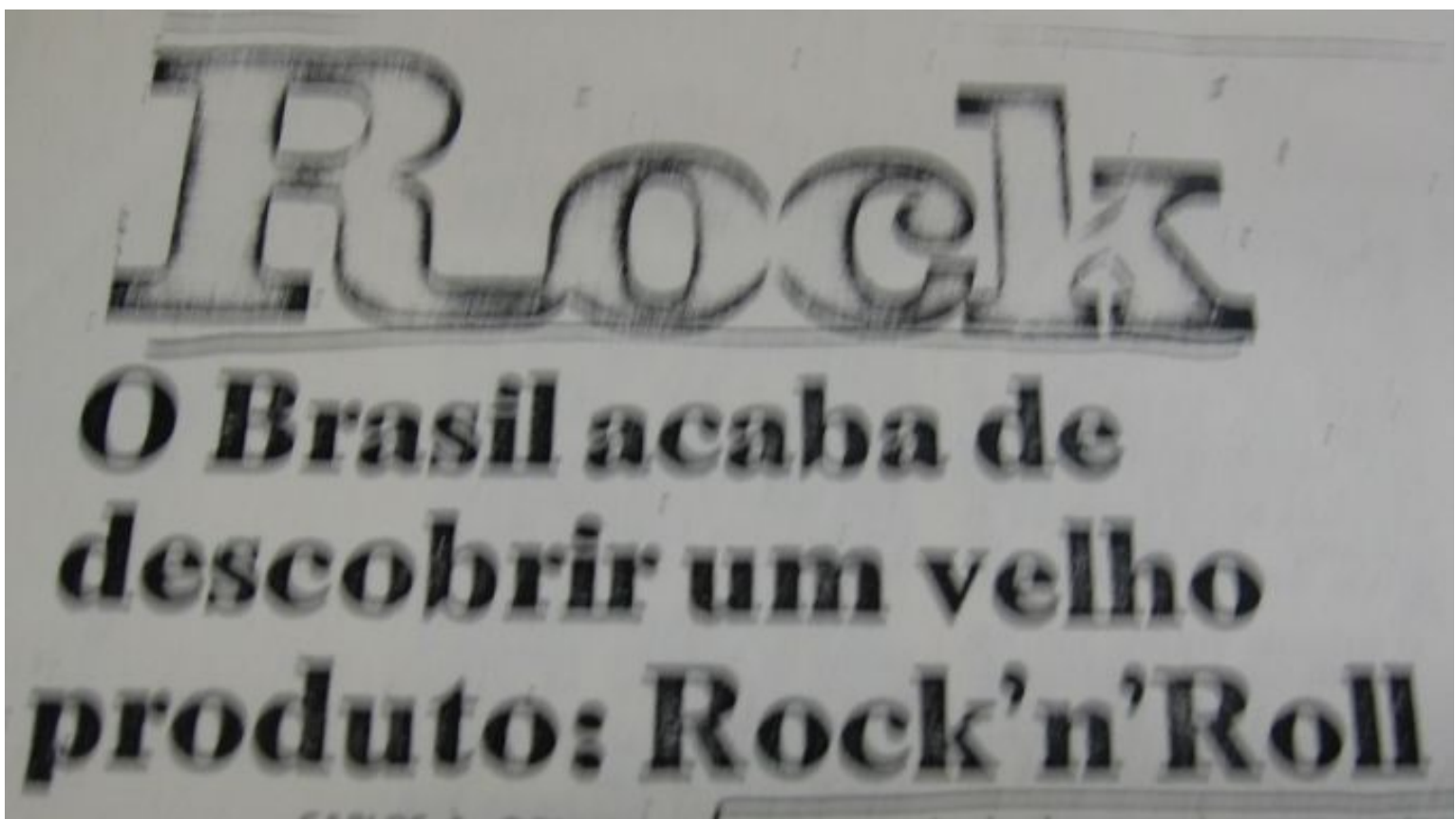

Fonte: Folha de São Paulo, 21 de outubro de 1974

O jornal já destacava bandas como o Made in $\mathrm{Brazil}^{148}$, e o crescimento de novos grupos musicais. $A$ sua edição de 24 de março de 1975 trazia a matéria "A UNIÃO DO ROCK BRASILEIRO". Mostrando que o Brasil poderia criar música de qualidade nesse estilo.

O rock chegou para ficar. Chegou no Brasil e está demonstrando que nos dias de hoje, após 27 anos de existência em outros países e 17 anos no Brasil, deturpado, com interpretações errôneas na boca dos cantores rotulados, marginalizados pelos produtores de televisão e desconhecido pelos programadores de rádio, ganha finalmente o seu ano de força (1975). A força total começou em 25 de janeiro de 1975, durante as festividades da cidade de São Paulo, quando o próprio prefeito Miguel Colassuolo reconheceu, admitiu e sentiu a necessidade da inclusão do rock, como média publicitária, para o gosto dos paulistanos. ${ }^{149}$

\footnotetext{
${ }^{148} \mathrm{~A}$ banda de rock mais antiga do Brasil, que ainda está na "estrada".

${ }^{149}$ FOLHA DE SÃO PAULO, 24 de março de 1975.
} 
Todos os jovens das diferentes classes, especialmente os de classe média, se renderam aos encantos do rock. Os festivais e eventos traziam milhares de pessoas. E ao abordar essa temática na mídia, verificava-se a consolidação do ritmo no Brasil. Por exemplo, na edição 25 de maio de 1976. Da Folha, viria a matéria "SURF E ROCK LEVAM 50 MIL A SAQUAREMA". Falava de um show de Raul Seixas e Rita Lee. Ressaltando o aspecto de entretenimento do evento.

O rock continuou seu crescimento, mas, mesmo assim, não conseguiu atingir a maior parte da juventude. Ainda era elitista e regionalizado. No final da década de 1970, o nosso rock nacional se restringia a poucas bandas e começava de forma gradua a decair. A MPB novamente era o ritmo mais tocado no país.

A juventude tinha perdido, aos olhos da sociedade, e perante ela mesma, o seu papel rebelde, contestador, de provocar a mudança. Apareceu a visão do jovem empreendedor, preocupado com o futuro e em "ganhar seu primeiro 1 milhão". De fato, um momento de burocratização da cultura juvenil. A Folha, no dia 30 de setembro de 1979 trazia a reportagem. "JUVENTUDE, APENAS UMA QUESTÃO DE MARKETING" Era uma nova visão dos jovens, fora do estereótipo de drogado e rebelde, como um ator social politicamente correto.

Quando se falava em fenômenos juvenis, nesse momento, o noticiado era o movimento disco-music americano e o frenesi causado pela banda As Frenéticas no Brasil (Figura 7).

Enquanto isso, começa a ocorrer na Inglaterra o Movimento Punk. No Brasil, ele vem desembarcar em 1979, nas periferias das grandes cidades. O punk nasce como algo contestador, anárquico, que tem elementos de violência atrelado ao seu discurso.

Em seu princípio, nada tinha a oferecer para uma indústria cultural. Suas atitudes atentavam contra os padrões sociais e ele só se mantinha vivo nos "guetos" e nos espaços das gangues periféricas. 
Figura 7 - Reportagem: Um frenesi

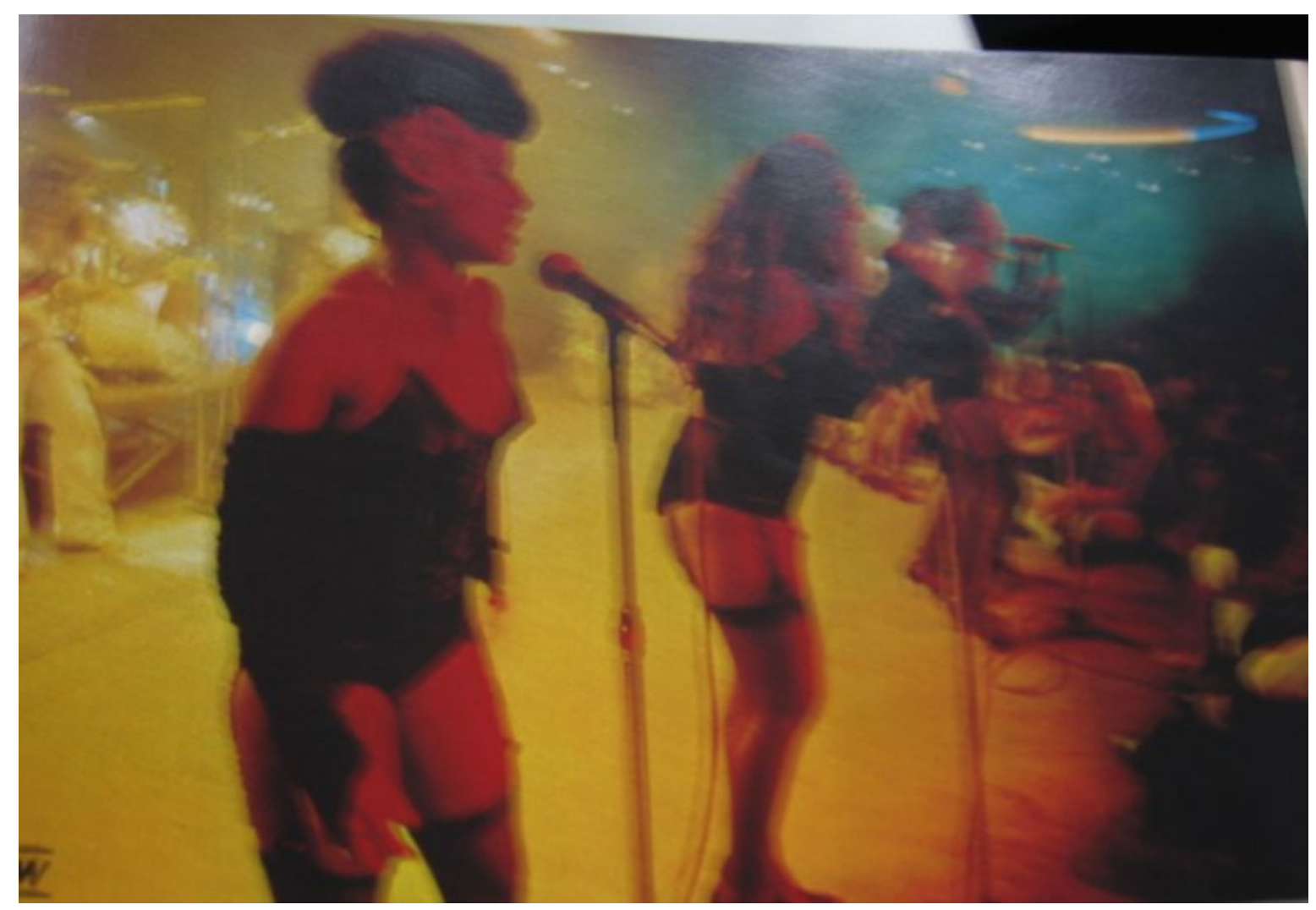

Fonte: Veja, n. 457 de 8 de junho de 1977

Por isso mesmo, sua aparição nos dos veículos de comunicação estudados foi quase nula nos primeiros anos de sua existência no Brasil. Quando apareciam nos noticiários sempre estavam atrelados a atos de violência isolados.

Podemos verificar isso na reportagem da Folha de 22 de dezembro de 1981. "PUNKS INVADEM SÃO VICENTE, DESTROEM CARROS E SÃO PRESOS". Em grande parte das matérias é ressaltado o sentimento "selvagem" dos punks. (Figura 8).

No começo dos anos 1980 é que os grupos punks começaram a fazer sucesso na Inglaterra. O Sex Pistols apareceu em programas de TV e vendeu milhares de discos em todo mundo. Aqui no Brasil, o movimento ainda não estava disseminado na classe média, mas a partir de sua absorção pelos adolescentes mais abastados, sua abordagem pela imprensa começou a mudar. 
Figura 8 - Reportagem: punks invadem São Vicente, destroem carros e são presos.

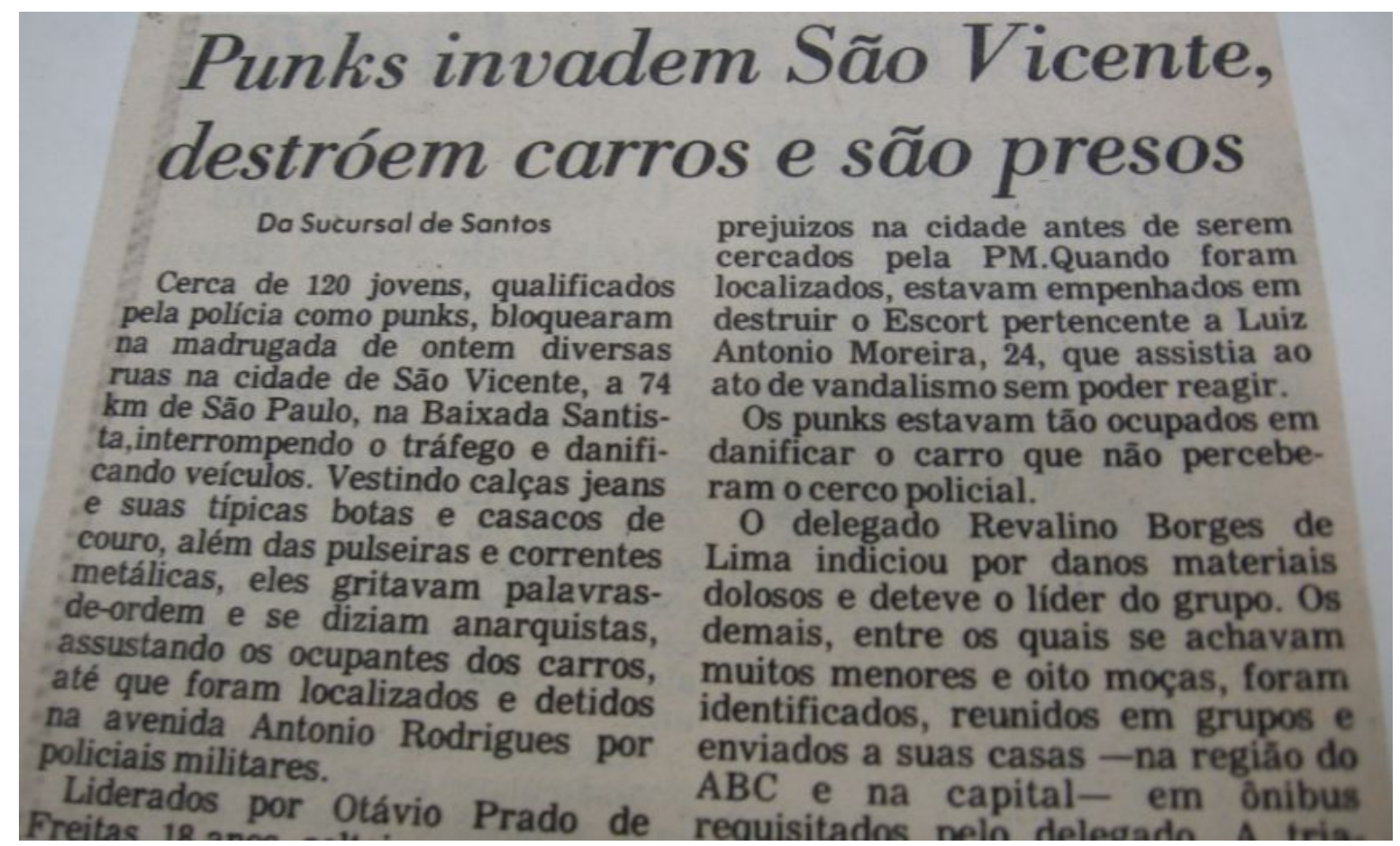

Fonte: Folha de São Paulo, 22 de dezembro de 1981.

A abertura do punk para as classes médias, a popularização do ritmo no exterior, a compra de discos no Brasil, o crescimento dos grupos nas metrópoles, além de outros fatores, mostraram a necessidade de mercantilização do movimento no país.

As gravadoras começaram a se abrir e a imprensa despiu-se do preconceito contra o punk para mostrar a nova "cara" dos conjuntos. Na revista Veja de agosto de 1982 aparece a reportagem: "CUIDADO COM ELES suburbano e pobre, o agressivo punk paulista ganha as ruas". A matéria conta o surgimento do movimento em Londres, e fala de bandas como Cólera e os Inocentes aqui no Brasil. 
O texto relatava a criação de novos espaços, agora no centro da cidade, longe das periferias. Locais esses, freqüentados também por jovens da classe média. Eles se encontravam em locais como a Galeria do Rock ${ }^{150}$.

Esse espaço se tornou ponto de encontro das tribos paulistanas. Identificação e consumo eram os elementos principais que os levavam para lá. Os punks se reuniam para comprar roupas, adereços e discos; produtos essenciais para reforçar a identidade como o movimento.

Os estilos jovens baseados nos novos movimentos e seus espaços de representação apareceram na Folha de 21 de fevereiro de 1982. "PUNK, NEW WAVE. REGGAE E NEW ROMANTICS: os filhos mal comportados do rock".

Todas essas palavras - e muitas outras mais - são tentativas da imprensa, da crítica, da indústria fonográfica - de classificar e ordenar o verdadeiro caos em movimento em que se transformou o até então monolítico rock (...) o rock se tornou mais do que uma mania passageira. É um estilo reconhecido e identificável de fazer música, com estratos de consumo bem definidos, uma linguagem própria. ${ }^{151}$

A aparição do punk nas páginas da revista se manteve presente, no decorrer do começo dos anos 1980, mas com a superexposição das bandas, e a transformação da estética punk em moda para a classe média, as notícias traziam referências mais comerciais da música e do estilo da juventude adepta.

Em 2 de dezembro de 1984, a Folha noticiava: "A ESTÉTICA PUNK VIROU MODA". Destituída de seu "elemento rude", o punk virou mero produto da indústria cultural. A Reportagem não tecia críticas a esse aspecto, apenas apontava as mudanças que ocorriam no mundo da moda.

Os designers de moda finalmente absorveram a estética punk. É só conferir as coleções de verão de algumas confecções, algumas vitrines de lojas e danceterias. Uma estética que é o resultado de uma criação livre

\footnotetext{
150 O Shopping Center Grandes Galerias foi construído na década de 1960, mas a partir dos anos 70 foi invadido por lojas de discos, o que atraiu muitos jovens.

${ }^{151}$ FOLHA DE SÃO PAULO, 21 de fevereiro de 1982.
} 
onde metais, estilhaços de vidro, alumínios e fios de computador entram em uma composição que, ao oposto do belo, não é agradável à vista. ${ }^{152}$

Algum tempo depois, em 27 de abril de 1986, "COM A INCORPORAÇÃO DO PUNK MORREU O PUNK". O mesmo jornal falava que "no protesto e transgressão da indumentária, o movimento pode estar morto e ser hoje mero exercício de estilo".

A imprensa acompanhava a tendência de mercantilização do movimento punk ocasionado pela sua descaracterização no mundo da Moda e pelo sucesso de seus artistas no mercado fonográfico.

Se, no começo da década de 1980, o punk brasileiro começava a se consolidar no mercado de consumo, o rock brasileiro queria também "mostrar serviço". As bandas nacionais viam o sucesso de grupos estrangeiros do crescente "new wave" e de novos estilos trazerem vida ao cenário musical no mundo inteiro.

O retrato era de uma consolidação lá fora, como verificamos na Veja n.601 de 12 de março de 1980: "O SONHO NÃO ACABOU: a inesperada volta do rock às paradas desconcerta as previsões e apresenta seus novos ídolos". Reportagem fala do nascimento do new wave com nomes como the Police, Dire Straits e The Clash (com seu rock anárquico). E como eles eram amplamente escutados pela juventude brasileira.

Com o surgimento do BRock no início da década, a aparição da Gang 90 e a pirotecnia da Blitz foram manchetes nos jornais. As bandas nasciam já como produtos comerciais vendáveis com forte apelo popular.

O Rock carioca traz novo ânimo para a juventude brasileira, tanto que em 31 de outubro de 1982. A folha trazia em uma de suas páginas: "A NOVA JOVEM GUARDA ANUNCIA: o pacote rock vai rolar nesse verão". A reportagem fala da consolidação dos gêneros rock e punk brasileiros.

152 FOLHA DE SÃO PAULO, 2 de dezembro de 1984. 
Apesar do grande impacto que o início do BRock trouxe para o mercado, a juventude ainda não se sentia representada pelas bandas nacionais. A Blitz era um grupo que agradava, especialmente, jovens de classe média carioca com um pequeno grau de politização.

Comparados ao período tropicalista e ao rock internacional pungente, nossos grupos e seus hits ficavam bem aquém das expectativas para a formação de um verdadeiro movimento cultural de juventude no Brasil.

Além do mais, como produtos midiáticos, essas primeiras bandas eram fugazes, por isso mesmo, a necessidade de uma renovação constante. A sua aparição freqüente nas propagandas e programas musicais, talvez, tenha cansado os jovens brasileiros, que necessitavam de um rock mais bem elaborado, como os de seus ídolos internacionais.

Essa tendência já se sentia presente na cobertura da mídia sobre a nossa música na Folha de São Paulo em 26 de outubro de 1983. "O ATUAL ROCK BRASILEIRO É UM PRODUTO ARTIFICIAL”. A reportagem fala da descrença no rock nacional e a fugacidade de suas músicas.

Nesse momento, que começam a crescer as bandas do chamado "rock politizado", como o Barão Vermelho e, de outro lado, bandas como o Ultraje a Rigor, trazendo uma música bem humorada mais com duras críticas sociais.

O contexto social era de uma dura crítica da imprensa e da sociedade com - Estado Militar, que tinha deixado o país em uma situação econômica complicada: altos índices de inflação, desigualdade social, o caos nos setores básicos essenciais. Com a reabertura, todos tinham a possibilidade de criticar, de falar o que pensavam e isso impulsionou o crescimento dessas bandas e possibilitou que a indústria cultural - agora, livre da influência "nefasta" do Regime Militar - pudesse comercializar tais discursos de protesto com produtos culturais.

Entendendo o novo momento do BRock, a Folha aponta no dia 5 de setembro de 1984 a reportagem. "ROCK CANTA OS MALES DA CRISE". A matéria falava das letras cômicas, exaltando o rock nacional que criticava o país 
através do humor e de uma "batida" consumível pelos jovens ávidos por novidades.

Na edição de 8 de setembro de 1984 destaca o fortalecimento do discurso político nas canções. "BARÃO VERMELHO ATACA DE NOVO". A reportagem mostra ascensão do rock da banda e Cazuza fala de uma juventude não alienada, diferente daquela pintada pela mídia.

Apesar de toda a sua crítica, o BRock não tinha uma posição tão revolucionária que nem o punk, por isso mesmo, a sua fácil aceitabilidade no mercado. A crítica social poderia ser facilmente mercantilizada. E, de fato, foi. As atitudes dos jovens amantes do rock nacional eram as de cantar, comparecer aos shows, comprar os discos, debater nas rodas de amigos e usar drogas como seus ídolos. Nenhuma revolução foi incitada, como queria ingenuamente o grupo RPM ao cantar: "toquem o meu coração/ façam a revolução/ que está no ar, nas ondas do rádio/ No submundo repousa o repúdio/ que deve despertar?'.

A revolução foi de pensamento, de cobrança, de protesto, como no movimento das Diretas. Mas a democracia possibilitava a busca de melhorias por vias mais diplomáticas. O rock brasileiro não tentou e nem tentaria algo como os músicos e jovens da contracultura se dispuseram a fazer. Nesse sentido, a Folha de São Paulo publicou a reportagem "UMA BATUCADA DE ROCK".

\begin{abstract}
Sem comprar briga com ninguém, o rock nacional vai alegremente ocupando espaço no mapa musical do país. Ele é o reflexo dos anos 80 . 0 rock tem o cheio e o gosto da juventude brasileira, mas não se presta a nenhuma cruzada nacionalista. Convive nacionalmente com o samba, e não que brigar com a geração dos mais velhos. No ano de 1984, as duas emissoras FM de maior audiência no país - a rádio 98 do Rio e a Jovem PAN, de São Paulo, alocavam entre $20 \%$ e $30 \%$ de sua programação com BRock em 1985 essa porcentagem pulou para 70\% além das rádios e gravadoras, a indústria de instrumentos musicais também cresceu. ${ }^{153}$
\end{abstract}

Escapar do triste destino da Blitz, que se tornou extremamente fútil aos olhos dos jovens da época, era o único caminho de sobrevivência das bandas. $O$

${ }^{153}$ FOLHA DE SÃO PAULO, 2 de janeiro de 1985. 
rock brasileiro tinha, agora, uma marca: a do protesto político. Ou, pelo menos, a de uma erudição nas suas letras. A possibilidade de mercantilização desse fenômeno foi aproveitada por toda a indústria cultural.

Na revista Veja n. 853 de 9 de janeiro de 1985 viria a reportagem "MANUAL DA TRIBO: os roqueiros ganham seu jornal". Depois de consagrar-se como ritmo do momento no Brasil, o rock ganhou agora um jornal inteiramente dedicado a ele. "A partir dessa semana, chega às bancas de todo o país o 'Viva Rock', que em 36 páginas impressas em cores, irá trazer mensalmente as últimas novidades sobre os artistas de rock nacionais e estrangeiros e tudo ligado a cultura rock" (Veja, 9 de janeiro de 1985).

O destaque nos jornais sempre era para bandas como o Barão Vermelho, Legião Urbana e cantores como Lobão. A politização do rock tinha virado um produto de consumo forte entre a juventude, tanto que a preferência, de uma boa parcela deles, estava direcionada para os conjuntos que tivessem essa faceta. Novamente, a mídia acompanha, de perto, o desejo dos jovens.

Na Folha de 26 de março de 1985, era destacado o caráter "não-comercial" de um grupo. "ESTA NÃO É PARA TOCAR NA RÁDIO". Crítica à tentativa de mercantilização da Legião Urbana.

\begin{abstract}
Rebelde com causa, Renato Russo adianta que o tema do próximo disco dos Legionários Brasileiros será a situação política do país. Seis novas músicas já estão prontas e o legionário garante que eles serão um antídoto, talvez, para a falta de criatividade". Citação do cantor: "Não sei quem são os intelectuais brasileiros. Eles não falam nada. E é só aparecer um garoto de Brasília, fazendo letras mais legais que ficam dizendo: ó Hosana nas alturas!.
\end{abstract}

Essa opinião, de transformação do rock brasileiro em movimento, apareceria em várias outras matérias, como a da revista Veja n. 980 de 17 de junho de 1988: "GUERRA SOLITÁRIA: em Vida Bandida, o melhor disco de Lobão". Fala do novo trabalho do cantor e crítica o rock brasileiro cheio de "gracinha". 
Ou na mesma revista, em seu n. 981 de 2 de junho de 1987: "O SUCESSO É PERIGOSO". Reportagem com Lulu Santos, que fala da fugacidade dos roqueiros nacionais, e sua faceta consumista. Segundo o cantor: "eu simplesmente faço música porque gosto. É possível que os adolescentes rebeldes se identifiquem mais com grupos como a Legião Urbana. Mas não estou preocupado com isso".

Apesar de acreditar no crescimento do rock brasileiro como movimento, e que isso poderia conclamar toda a juventude, revertendo isso em consumo na indústria fonográfica e nos outros sistemas harmônicos, era inegável o avanço que o pop tinha no mundo.

Os elementos incorporados dos grandes astros mundiais estavam mudando a cara da música brasileira também. Na Folha de 17 de janeiro de 1984, estava a matéria: "VIDEO-ROCK, UMA NOVA FORMA DE DIZER" Reportagem fala do videoclipe e da mercantilização da música, através de uma embalagem melhor.

Isso era corroborado pelo sucesso feito com os clipes de astros como Michael Jackson e Madonna. "AS NOVAS ESTRELAS DO ROCK". Fala-se de Madonna, um novo rock intrigante e vigoroso: um rock feito de imagem. (Folha de São Paulo, 17 de março de 1985).

Enquanto o mercado se preparava para absorção de elementos pop na música nacional - a partir do final da década -, o BRock ainda foi produto de destaque até o final dos anos 1980.

De fato, a tendência da mídia foi a de exaltação da Legião e do Barão Vermelho, e sacralização de grupos como o Blitz. Coincidentemente, as bandas exaltadas mantiveram-se no sucesso por muito tempo. E se tornaram a referência ao se falar de Cultura da Juventude no período dos anos 1980. 


\section{CAPÍTULO V \\ CONCLUSÃO}

Essa pesquisa apresenta os principais aspectos da cultura da juventude no Brasil nas décadas de 1970 e 1980 e sua relação direta com a Indústria Cultural e o consumo.

É importante retornar à motivação desse estudo: entender o papel da comunicação midiática - no caso, as publicações impressas (Revista Veja e Jornal Folha de São Paulo) - na formação da cultura da juventude nas décadas de 1970 e 1980 no Brasil, com relação à sua abordagem sobre as manifestações; e se ela é influenciada diretamente pela mercantilização desses movimentos.

Tal questionamento esteve ligado diretamente aos objetivos propostos: verificar os principais movimentos e fenômenos de juventude no Brasil, tanto em suas perspectivas históricas, como em sua relação com a indústria cultural e; apresentar exemplos da abordagem dos meios de comunicação estudados sobre tais manifestações e relacioná-los ao processo de mercantilização dos mesmos.

Com base no material coletado e analisado - segundo a metodologia apontada -, podemos tecer algumas conclusões.

A primeira é que os movimentos juvenis espontâneos se consolidaram com base na "rebeldia" e na transformação da sociedade. Os jovens, desde a década de 1950, com o surgimento do rock, se travestiram do papel de revolucionários. De certa forma, é um papel que a própria sociedade os impõe. Desse modo, as manifestações verificadas sempre primaram pela ruptura, jamais pelo conformismo ou sentimento reacionário.

Um segundo ponto importante é que os representantes de manifestações juvenis perceberam que a mídia era veículo essencial para o seu fortalecimento e sua aparição nos meios de comunicação não poderia ser pensada, somente, de forma negativa. 
A Contracultura, por exemplo, soube utilizar a indústria cultural de forma benéfica para a sua consolidação. Apesar de ter surgido como movimento espontâneo, o tropicalismo utilizou-se da propaganda e da TV, como forma até de fazer uma crítica aos próprios meios. Raul Seixas acreditava que através dos veículos de comunicação poderia espalhar a mensagem da Sociedade Alternativa por todo país.

Algumas manifestações se mantiveram arredias aos meios de comunicação como os punks, mas utilizaram de outros meios da indústria cultural como a moda.

O movimento punk só pode chegar ao Brasil, através da indústria fonográfica. Isso mostra a dependência dessa manifestação em relação ao mercado. Se o punk escutado nas periferias da cidade era o que primeiro despontou, os próprios jovens adeptos dessas localidades começaram a consumir o punk comercial dos Inocentes ou da Plebe Rude algum tempo depois.

Destaco também a formação dos fenômenos juvenis criados pelo Mercado Fonográfico. Desses, a conclusão que podemos tirar é de sua efemeridade e fugacidade. Por não possuírem conteúdo e sua mensagem ser "vazia", acabam se esgotando rapidamente. O interessante é que, com o tempo, o Mercado compreendeu esse processo e conseguiu, através do pop, incorporar a novidade e transformação nas músicas de seus artistas, através de estratégias de marketing bem elaboradas.

Estratégias essas que foram sendo incorporadas pelas bandas do underground, como foi o caso do RPM. Ou através de grandes eventos como o Rock in Rio.

A mercantilização de movimentos juvenis não é necessariamente negativa para a cultura jovem. $O$ grande problema é o desgaste e a interferência desse Mercado na obra dos artistas. Na década de 1980, bandas como a Legião Urbana e o Barão Vermelho tinham liberdade quase que total para a sua produção musical, talvez por isso, tenham sobrevivido por tanto tempo. 
Sobre a relação da mídia escrita com os outros sistemas da indústria cultural, pudemos perceber que ela foi marcante e, por várias vezes, comprovada, através das análises feitas no último capítulo.

A abordagem da Veja e da Folha teve relação direta com a mercantilização dos movimentos. Enquanto o punk figurava no circuito underground, não aparecia nas reportagens, somente tinha destaque os atos de violência relacionados a adeptos do movimento. $\mathrm{O}$ aparecimento do punk no circuito comercial, o aumento de adeptos e de venda discos obrigou que os veículos dessem mais ênfase à sua participação na cultura da juventude brasileira.

Como eu já ponderei anteriormente, existem outros motivos implícitos na mudança, mas o do caráter de comercialização do punk pela indústria cultural, figura com um dos mais marcantes.

Desse modo, voltamos ao questionamento inicial, o papel das mídias na formulação da cultura jovem. Quando propus o problema, sabia que ele talvez não fosse resolvido em sua totalidade e, claro, não poderia. Quaisquer conclusões tiradas sobre a "manipulação" dos jovens através desses meios estudados seria uma leviandade.

$O$ que realmente quis apresentar foi uma imagem das manifestações. $A$ imagem construída através dos meios de comunicação. A análise principal desse trabalho é a de contribuir com os estudos sobre a relação entre essas culturas e o consumo.

Para supor qualquer coisa sobre uma influência dos meios nos jovens, teria que acreditar que eles têm esse poder e além do mais, existe todo um corpo de outras informações que seriam utilizadas para mediar tais conteúdos. A proposta foi olhar a abordagem de tais meios de comunicação, para que pudessem ilustrar esse processo que, ao decorrer do trabalho, chamei de "mercantilização". Termo que no contexto do nosso trabalho, pode ser entendido como o fato de uma cultura espontânea (em alguns casos), atrair a atenção do público em circuitos alternativos e ser comercializada pela indústria cultural, para que possa expandir sua música ou comportamento para mais consumidores. 
Atuando distintamente em cada movimento, como percebemos na pesquisa, a indústria cultural acaba, de fato, englobando tais culturas jovens. Só que, a partir de fontes secundárias (os autores e teóricos), essas conclusões não teriam tanto respaldo.

A abordagem da mídia impressa demonstrou o próprio interesse da indústria cultural sobre tais movimentos.

Por isso mesmo, o papel de formação dos veículos impressos na cultura da juventude brasileira foi, ao meu ver, juntamente com outros fatores menos importantes, o de reiteração do consumo. De validação do que é considerado produto cultural pelo mercado. Tudo isso, diretamente influenciado pelo contexto histórico, cultural e econômico vivido pela sociedade brasileira em cada momento estudado.

\subsection{SUGESTÕES PARA NOVAS PESQUISAS}

O tema Cultura da Juventude é amplo e pode ser abordado de várias outras maneiras, como através do comparativo entre meios de comunicação, encontrando especificidades nas abordagens do meio.

Outra pesquisa interessante seria a de fazer a mesma abordagem no período da década seguinte, os anos 1990. Procurando entender as características principais da cultura dos jovens no contexto da consolidação do pop. 


\section{REFERÊNCIAS BIBLIOGRÁFICAS}

ABRAMO, H. Cenas juvenis: punks e darks no espetáculo urbano. São Paulo: Scritta, 1994.

ADORNO, T. W. A Indústria Cultural. In: COHN, Gabriel (org.). Comunicação e Indústria Cultural. São Paulo: T.A. Queiroz, 1989.

. Televisão, consciência e Indústria Cultural. In: COHN, Gabriel (org.). Comunicação e Indústria Cultural. São Paulo: T.A. Queiroz, 1989.

ARANTES, A. A. O que é cultura Popular? São Paulo: Brasiliense, 1981.

BAHIANA, A. M. MPB nos anos 70. Rio de Janeiro: Ed. Civilização Brasileira, 1980.

BAKHTIN, M. A Cultura Popular na Idade Média e no Renascimento: o contexto de François Rabelais. Brasília: ed. da UnB, 1996.

BAUDRILLARD, J. A Sociedade de Consumo. Rio de Janeiro: Elfos, 1995.

. Para uma crítica da economia política do signo. Rio de Janeiro:

Elfos, 1995.

BENEDICT, R. O crisântemo e a espada. São Paulo: Perspectiva, 1972.

BENJAMIN, W. A Obra de Arte na Época de Sua Reprodutibilidade Técnica. In: Costa Lima, Luiz (org.). Teoria da Cultura de Massa. Rio de Janeiro: Paz e Terra, 1978.

Suhrkamp, 1982.

Das Passagen-Werk. Organização de R. Tiedermann. Frankfurt,

BIVAR, A. O que é punk? São Paulo. Abril, 1983. 
BORELLI, S. S. Cultura brasileira: exclusões e simbioses. In: ANOS 70: Trajetórias. São Paulo: lluminuras - Itaú Cultural, 2005.

BOSCATO, L. A. Vivendo a sociedade alternativa: Raul Seixas no panorama da contracultura jovem. Tese (Dourado). Faculdade de Filosofia, Letras e Ciências Humanas da Universidade de São Paulo, 2006.

BOURDIEU, P. Pierre Bourdieu: sociologia. (coletânea organizada por Renato Ortiz). São Paulo: Ática, 1983.

BRYAN, G. Videoclipe brasileiro: história, características e internacionalidade. Dissertação (Mestrado). Escola de Comunicações e Artes da Universidade de São Paulo, 2005.

CALDAS, W. Cultura da Juventude nas décadas de 1950 e 1960. São Paulo: Musa Editora, 2008.

CALADO, C. A divina comédia dos mutantes. Rio de Janeiro: Ed. 34, 1995.

CARMO, P. S. Culturas da Rebeldia: a juventude em questão. São Paulo: Editora Senac, 2001.

CHAUÍ, M. Conformismo e resistência: aspectos da cultura popular no Brasil. São Paulo: Brasiliense, 1986.

. Cultura e Democracia: o discurso competente e outras falas. São Paulo: Cortez, 1989

COELHO, C. N. A contracultura - o outro lado da modernização autoritária. Cláudio Novaes Pinto Coelho. In: ANOS 70: Trajetórias. São Paulo: lluminuras Itaú Cultural, 2005.

CORRÊIA, T. G. Rock nos passos da moda: mídia, consumo x mercado cultural. Campinas: papirus, 1991.

ELIOT, T. S. Notas para uma definição de Cultura. Coleção Debates - Filosofia. São Paulo: Editora Perspectiva, 1988. 
FAVARETTO, C. Tropicália - alegoria, alegria. São Paulo: Ateliê Editorial, 1996.

FEATHERSTONE, M. Cultura do Consumo e Pós-modernismo. São Paulo: Estúdio Nobel, 1995.

FIGUEIRA NETO, A. O. Baby Boomers, um perfil de quem está por trás da explosão de consumo nos Estados Unidos da América. Dissertação de Mestrado. Escola de Comunicação e Artes de São Paulo, 1996.

GONÇALVES, P. V. Ser punk: a narrativa de uma identidade jovem centrada no estilo e sua trajetória. Dissertação (Mestrado). Faculdade de Educação da Universidade de São Paulo, 2005.

GROPPO, L. A. O Rock e a formação do mercado de consumo juvenil - a participação da música pop-rock na transformação da juventude em mercado consumidor de produtos culturais, destacando o caso do Brasil e os anos 80 . Dissertação (Mestrado). Universidade Estadual de Campinas, 1996.

GUERREIRO, A. S. Retratos de uma tribo urbana: rock brasileiro. Dissertação (mestrado). Faculdade de Filosofia, Letras e Ciências Humanas da Universidade de São Paulo, 1991.

KEHL, M. R. As duas décadas dos anos 70. Maria Rita Kehl. P. 31-37. In: ANOS 70: Trajetórias. São Paulo: Iluminuras - Itaú Cultural, 2005.

KEMP, K. Grupos de estilo jovens: o rock underground e as práticas (contra) culturais dos grupos punk e trash em São Paulo. Dissertação (Mestrado). Faculdade de Antropologia da Universidade Estadual de Campinas, 1993.

LANDOWSKI, Eric; FIORIN, José Luiz. O Gosto da gente, o gosto das coisas: abordagem semiótica. São Paulo: EDUC, 1997

LARAIA, R. B. Cultura: um conceito antropológico. Rio de Janeiro: Jorge Zahar Editor, 1988.

LE BON, M. Psychologie des foules. 5 ed., Paris: PUF, 1995. 
LEVI, G.; SCMITT, J. C. História dos Jovens: da antiguidade à Era Moderna. São Paulo: Companhia das Letras, 1996a.

. História dos Jovens: a época contemporânea. São Paulo:

Companhia das Letras, 1996b.

LUCAS, C. A. A Odisséia do disco na produção de segmento. Dissertação (Mestrado). Escola de Comunicações e Artes da Universidade de São Paulo, 2004.

MAFFESOLI, M. O tempo das tribos: o declínio do individualismo nas sociedades de massa. Rio de Janeiro: Forense Universitária, 2000.

MARTíN-BARBERO, J. Dos meios às mediações: comunicação, cultura e hegemonia. Rio de Janeiro: Editora UFRJ, 2003.

MEDEIROS, P. T. Mutações do sensível: rock, rebeldia pós-68. João pessoa: Manufatura, 2004.

MOLES, A. Linguagem da cultura de massas: televisão e canção. Petrópolis: Vozes, 1973, p. 8.

MOREIRA, R. S. Teoria da Comunicação: ideologia e utopia, em busca de elementos teóricos para a leitura ideológica da indústria cultural. Petrópolis: Vozes, 1979.

ORTIZ, R. Cultura brasileira e identidade nacional. 4ª Ed. São Paulo: Brasiliense, 1994.

A moderna tradição brasileira. São Paulo: Brasiliense, 1999.

PACHECO, E. D. (org). Comunicação, educação e arte na cultura infanto-juvenil. São Paulo: Edições Loyola, 1991.

PACKARD, V. Estratégia do desperdício. São Paulo: Ibrasa, 1965. 
PEREIRA, C. A. O que é Contracultura? IN: O que é Cultura, Contracultura e Política Cultural. Coleção Primeiros Passos. São Paulo: Círculo do Livro, s/d.

RISÉRIO, A. Duas ou três coisas sobre a contracultura no Brasil. In: ANOS 70: Trajetórias. São Paulo: lluminuras - Itaú Cultural, 2005.

SANTARELLI, C. P. Moda e Processo: um estudo sobre os jovens moradores da Periferia de São Paulo. Dissertação. Universidade de São Paulo, 2002.

SANTOS, R. A. O estilo que ninguém segura: mano é mano! Boy é Boy! Boy é Mano? Mano é Mano? Dissertação de Mestrado. Escola de Comunicações e Artes da Universidade de São Paulo, 2002.

SEVCENKO, N. Configurando os anos 70: a imaginação no poder e arte nas ruas. In: ANOS 70: Trajetórias. São Paulo: lluminuras - Itaú Cultural, 2005.

SOUSA, M. W. Jovens e telenovela: seduções da vida cotidiana. IN: PACHECO, E. D. (org). Comunicação, educação e arte na cultura infanto-juvenil. São Paulo: Edições Loyola, 1991.

SWINGEWOOD, A. O mito da cultura de massa. Rio de Janeiro: Editora Interciência, 1978.

WABNER, p. Imaginários, Esferas culturais e Planejamento: Disponível em: http://www.assesc.com.br Acesso em 12 de janeiro de 2008.

WILLIAMS, R. Cultura. São Paulo: Paz e Terra, 2000.

WOLF, M. Teorias da Comunicação de Massa. São Paulo: Martins Fontes, 2003. 